UNIVERSIDADE DE BRASÍLIA - UNB INSTITUTO DE GEOCIÊNCIAS - IG

SIGNIFICADO E INFLUÊNCIA DO LINEAMENTO ALEGRE NA EVOLUÇÃO TECTÔNICA DA BACIA DE CAMPOS E MARGEM CONTINENTAL ADJACENTE, SUDESTE DO BRASIL

DISSERTAÇÃO DE MESTRADO

$\mathbf{N}^{0} 350$

SALOMÃO SILVA CALEGARI

BRASÍLIA - DF 


\title{
SIGNIFICADO E INFLUÊNCIA DO LINEAMENTO ALEGRE NA EVOLUÇÃO TECTÔNICA DA BACIA DE CAMPOS E MARGEM CONTINENTAL ADJACENTE, SUDESTE DO BRASIL
}

\author{
DISSERTAÇÃO DE MESTRADO \\ $\mathbf{N}^{\circ} 350$
}

\section{SALOMÃO SILVA CALEGARI}

Orientador: Prof. Dr. George Sand Leão Araújo de França (UnB)

Coorientadora: Profa. Dra. Mirna Aparecida Neves (UFES)

\section{Banca Examinadora}

Prof. Dr. George Sand Leão Araújo de França (UnB)

Prof. Dr. Elton Luiz Dantas (UnB)

Prof. Dr. Francisco Hilário Rego Bezerra (UFRN)

Suplente: Prof. Dr. José Oswaldo de Araújo Filho (UnB)

$$
\text { BRASÍLIA - DF }
$$




\section{FICHA CATALOGRÁFICA}

Calegari, Salomão Silva

Significado e influência do Lineamento Alegre na evolução tectônica da Bacia de Campos e margem continental adjacente, Sudeste do Brasil/ Salomão Silva Calegari; orientação de George Sand Leão Araújo de França e coorientação de Mirna Aparecida Neves. Brasília, 2015.

$75 \mathrm{p}$.

Dissertação de Mestrado (M) - Universidade de Brasília / Instituto de Geociências, 2015.

1. Estruturas rúpteis 2. Reativação 3. Lineamento Alegre

I. Universidade de Brasília. Instituto de Geociências.

\section{REFERÊNCIA BIBLIOGRAFICA}

CALEGARI, S. S. Significado e influência do Lineamento Alegre na evolução tectônica da Bacia de Campos e margem continental adjacente, Sudeste do Brasil. Brasília: Instituto de Geociências, Universidade de Brasília, 2015, 75 p. Dissertação de Mestrado.

\section{CESSÃO DE DIREITOS}

NOME DO AUTOR: Salomão Silva Calegari

TÍTULO DA DISSERTAÇÃO DE MESTRADO: Significado e influência do Lineamento Alegre na evolução tectônica da Bacia de Campos e margem continental adjacente, Sudeste do Brasil.

\section{GRAU: Mestre AN0: 2015}

É concedida à Universidade de Brasília permissão para reproduzir cópias desta dissertação de mestrado e para emprestar ou vender tais cópias somente para propósitos acadêmicos e científicos. O autor reserva-se a outros direitos de publicação e nenhuma parte desta dissertação de mestrado pode ser reproduzida sem a autorização por escrito do autor.

Salomão Silva Calegari

(28) 99985-1138

salomaocalegari@hotmail.com 
Dedico este trabalho a:

minha mãe Ernesta de Fátima, minha irmã Julieta Rachelle, e meu pai Humberto (in memoriam). 


\section{AGRADECIMENTOS}

Ao Instituto de Geociências - IG da Universidade de Brasília - UnB pela oportunidade e apoio na busca pelo conhecimento, e a todos os professores do Programa de Pós-Graduação em Geologia pelo conhecimento adquirido nesses anos.

À Universidade Federal do Espírito Santo-UFES pelo espaço cedido para a realização de parte dos estudos.

À Coordenação de Aperfeiçoamento de Pessoal de Nível Superior (CAPES) pela bolsa de estudos.

À Financiadora de Estudos e Projetos (FINEP) pelos recursos que possibilitaram os trabalhos de campo (Convênio 01.10.0808.00).

À Agência Nacional do Petróleo (ANP) pela concessão das seções sísmicas 2D e dados de poços.

À minha amiga e coorientadora Mirna Aparecida Neves pela atenção e companheirismo, que de maneira eficaz soube transmitir seu conhecimento e experiência ao longo de nossos trabalhos.

Ao meu orientador George Sand Leão Araújo de França pelo total apoio e confiança para a realização deste estudo.

Ao Felipe Guadagnin pelo apoio e esforço na elaboração do artigo.

À Maria Gabriela Castilho Vincentelli pelo apoio e ensinamentos na interpretação sísmica, e a todo o pessoal da UNESP pelo acolhimento: Ariane Cortês, Dimitri Veloso, Douglas Souza Morais, Iata Anderson de Souza e Ricardo Schmidt.

Aos amigos Arthur Bazoni Fonseca e Julia Peixoto de Oliveira pelas discussões geológicas ao longo deste estudo.

Ao amigo Cleidson Barbosa Lorenzoni pelo auxílio na confecção das figuras deste trabalho.

À minha família, que sempre deu suporte para a total dedicação ao projeto de mestrado, minha mãe Ernesta de Fátima Silva Calegari e minha Irmã Julieta Rachelle Silva Calegari.

À Jayne Gonçalves Pereira pela compreensão e total apoio nesta grande jornada de minha vida.

Aos companheiros de UFES e UnB pelo apoio pessoal na realização deste trabalho: André Gomes Lima, Bruno Fernandes de Sousa, Davi Oliveira Saldanha, Haroldo Monteiro Lima, Lauro Cézar Montefalco de Lira Santos, Leandro de Oliveira, Leonardo Dellarmelina, 
Matheus de Sá Fortes Biccas, Muller Ismael Carlette Martins de Sá Fortes, Paula Otoni Pereira Ronzani Santos, Vinícius Dutra Silva, Victor Augusto Costa Andrade e Victor Ribeiro Corrêa. 
"A satisfação está no esforço e não apenas na realização final”.

(Mahatma Gandhi) 


\section{RESUMO}

O desenvolvimento e o arcabouço estrutural das bacias da margem leste do continente SulAmericano estão intimamente associados ao arcabouço tectônico e às heterogeneidades crustais herdadas do Embasamento Pré-cambriano. Contudo, o papel de estruturas de direções NW-SE e NNW-SSE presentes no Embasamento aflorante e sua influência na evolução dessas bacias ainda não receberam atenção necessária. Na região continental adjacente à Bacia de Campos, observa-se uma feição geológica de direção NNW-SSE denominada, no presente trabalho, de Lineamento Alegre. O objetivo principal deste trabalho é o estudo da constituição deste Lineamento e de sua influência na evolução tectônica da porção central da Bacia de Campos e na área continental adjacente, abrangendo o Sul do Estado do Espírito Santo e o extremo Norte do Estado do Rio de Janeiro. A investigação da área continental foi realizada com dados de sensoriamento remoto e observações de campo e, em subsuperfície, por meio da interpretação de seções sísmicas 2D e correlação com perfis geofísicos de poços. A integração dos dados revelou que, tanto em área continental quanto em área oceânica, o Lineamento Alegre constitui um conjunto de fraturas originadas no Cambriano, que foram reativadas no Cretáceo Inferior e entre o Paleoceno e Oligoceno sob a forma de falhas normais de direção NNW-SSE. Na bacia de Campos, essas estruturas atuaram na compartimentação do Baixo Corvina-Parati durante a fase rifte, com reativações no início do Paleoceno até o final do Oligoceno, resultando em um complexo sistema junto às falhas de transferência NW-SE e às falhas NE-SW.

Palavras-chave: estruturas rúpteis, reativação, Lineamento Alegre. 


\begin{abstract}
The development and structural framework of the basins along the eastern margin of the South American continent are closely associated with the tectonic framework and crustal heterogeneities inherited from the Precambrian Basement. However, the role of NW-SE and NNW-SSE structures of the outcropping basement and its influence on the development of those basins has not been correlated. In the continental region adjacent to the Campos Basin there is a geological feature with NNW-SSE orientation, referred to in this paper as the Alegre Lineament, which marks the exposed basement and can project from the coastal basin up to important oil sites. The main goal of this work is to study the constitution of this lineament and its influence on the tectonic evolution of the central portion of the Campos Basin and adjacent mainland in Brazil's southeastern region. The onshore area was investigated through remote sensing data and fields observations and the offshore area was studied through the interpretation of 2-D seismic sections and correlation with geophysical well logs. We concluded that the Alegre Lineament acted in both the onshore and offshore area as a group of fractures that originated in the Cambrian, which was reactivated in the Lower Cretaceous and between the Paleocene and Oligocene as normal faults with NNW-SSE direction. In the Campos Basin, the Alegre Lineament acted in the control of Corvina-Parati Low during the rift phase, and was reactivated in the early Paleocene to the late Oligocene, resulting in a complex system with the NW-SE transfer faults and NE-SW faults.
\end{abstract}

Keywords: brittle structures, reactivation, Alegre Lineament. 


\section{LISTA DE ILUSTRAÇÕES}

\section{CAPÍTULO I}

Fig. 1. 1: Mapa de localização da área de estudos. Cidades: $A=$ Alegre, $C I=$ Cachoeiro de Itapemirim, $\mathrm{CG}=$ Campos dos Goytacazes, $\mathrm{G}=$ Guarapari, $\mathrm{L}=$ Lajinha, $\mathrm{V}=$ Vitória. Estados: ES = Espírito Santo, RJ = Rio de Janeiro, $\mathrm{MG}=$ Minas Gerais. Rodovias e drenagens extraídos de Geobases (2002), batimetria extraída de GEBCO (2013), imagem ASTER GDEM (Advance Space Borne Thermal Emission and Reflection Radiomete-Global Digital Elevation Model Shuttle Radar Topography Mission) de ERSDAC (2013), campos de produção de óleo e gás de BDEP (2013). 18

Fig. 1. 2: Mapa de localização dos afloramentos visitados. Drenagem extraída de Geobases (2002), imagem ASTER GDEM (Advance Space Borne Thermal Emission and Reflection Radiomete-Global Digital Elevation Model Shuttle Radar Topography Mission) de ERSDAC (2013). Os polígonos representam o buffer de $40 \mathrm{Km}$ (vermelho) e o buffer de $3 \mathrm{Km}$ (roxo).

Fig. 1. 3: Mapa de localização dos dados utilizados em subsuperfície. Drenagem extraída de Geobases (2002), batimetria extraída de GEBCO (2013), imagem ASTER GDEM (Advance Space Borne Thermal Emission and Reflection Radiomete-Global Digital Elevation Model Shuttle Radar Topography Mission) de ERSDAC (2013). As linhas representam o polígono de interpolação (branco) e as linhas sísmicas (cinza). Os pontos em rosa representam os poços. 23

Fig. 1. 4: Coluna cronoestratigráfica da Bacia de Campos e horizontes interpretados (simplificado de Winter et al. 2007). 24

\section{CAPÍTULO II}

Fig. 2. 1: Arcabouço geológico da área de ocorrência do Lineamento Alegre na porção continental e sua projeção para a região oceânica, onde se localizam os principais campos petrolíferos brasileiros. Geologia simplificada de Silva et al. (2004), batimetria extraída de GEBCO (2013), imagem ASTER GDEM (Advance Space Borne Thermal Emission and Reflection Radiometer-Global Digital Elevation Model Shuttle Radar 
Topography Mission) de ERSDAC (2013), Falha de Campos de Guardado et al. (2000), campos de produção de óleo e gás de BDEP (2013), zonas de cisalhamento de Alkmim et al. (2006). Principais zonas de cisalhamento: $\mathrm{G}=$ Guaçuí, $\mathrm{B}=$ Batatal, $\mathrm{P}=$ Além Paraíba. Cidades: $\mathrm{A}=$ Alegre, $\mathrm{CI}=$ Cachoeiro de Itapemirim, $\mathrm{CG}=$ Campos dos Goytacazes, GP = Guarapari, L = Lajinha, V = Vitória. Estados: ES = Espírito Santo, $\mathrm{RJ}=$ Rio de Janeiro, $\mathrm{MG}=$ Minas Gerais 28

Fig. 2. 2: Localização dos afloramentos estudados na área continental e, na Bacia de Campos, a localização da área de interpolação com as seções sísmicas e os poços utilizados. ES = Espírito Santo, $\mathrm{RJ}=$ Rio de Janeiro, $\mathrm{MG}=$ Minas Gerais 34

Fig. 2. 3: Ilustração dos marcadores estratigráficos identificados nos poços utilizados para definir a idades dos horizontes sísmicos (simplificado de Winter et al., 2007). Intervalos estratigráficos: 1 = Embasamento, 2 = Sequência Rifte, 3 = Sequência Pós-Rifte, 4 = Sal, 5 = Albiano, 6 = Cenomaniano-Maastrichtiano, 7 = Paleoceno-Oligoceno, $8=$ Mioceno-Pleistoceno, TB = Topo dos basaltos, DNPA = Discordância Pré-NeoAlagoas, DPE = Discordância Pré-Evaporítica 35

Fig. 2. 4: Contexto regional da área de influência do Lineamento Alegre na porção continental da área de estudo. (a) Mapa de lineamentos em imagem de relevo sombreado (iluminação de NE), mostrando o traçado do Lineamento Alegre e o diagrama de rosetas, (b) Mapa geológico da região do Maciço Santa Angélica (modificado de Vieira, 1997 e Wiedemann-Leonardos et al., 2000); e (c) Imagem de relevo sombreado (iluminação de NE e NW sobrepostas), mostrando a localização dos diques máficos (círculos em preto) no traçado do Lineamento Alegre (indicado pelas setas brancas). Litologias: $\mathrm{EmPp}=$ Embasamento Paleoproterozóico, $\mathrm{EmNp}=$ Embasamento Neoproterozóico, GrNp = Granitóides Neoproterozóicos, GrC = Granitóides póscolisionais Cambrianos, $\mathrm{GbC}=$ Gabros Cambrianos, $\mathrm{DAC}=$ Depósitos aluviocoluvionares Cenozoicos. Diques: LA = Lajinha, IT = Itaici, JM = Jerônimo Monteiro, $\mathrm{MU}=$ Muqui.

Fig. 2. 5: Projeções estereográficas (projeção de hemisfério inferior em rede de igual área) das estruturas planares (foliações, juntas e falhas) adquiridas em campo mostradas em buffers de 40 e $3 \mathrm{Km}$ do Lineamento Alegre. (a) Foliações das rochas ígneas e metamórficas (buffer de $40 \mathrm{Km}$ ), (b) foliações das rochas ígneas e metamórficas (buffer de $3 \mathrm{Km}$ ), (c) juntas (buffer de $40 \mathrm{Km}$ ), (d) juntas (buffer de $3 \mathrm{Km}$ ), (e) falhas normais (buffer de $40 \mathrm{Km}$ ), (f) falhas normais (buffer de $3 \mathrm{Km}$ ), (g) falhas transcorrentes destrais 
(buffer de $40 \mathrm{Km}$ ), (h) falhas transcorrentes destrais (buffer de $3 \mathrm{Km}$ ). n = número de medidas.

Fig. 2. 6: Estrias de falhas marcadas em planos de falhas preenchidos por (a) óxido de Mn (N05W/45NE) e (b) argilo-minerais e/ou óxi-hidróxidos de Fe (N80E/55NW).

Fig. 2. 7: Campo de paleotensores obtido a partir da inversão dos dados de falhas no WinTensor por meio do método dos diedros retos mostrando distensão no quadrante NW-SE. $\mathrm{n}=$ número de dados representados/dados totais, $\sigma 1=$ eixo de tensão máxima, $\sigma 2=$ eixo de tensão intermediária, $\sigma 3$ = eixo de tensão mínima.

Fig. 2. 8: Seções sísmicas strike selecionadas dentre as 31 seções interpretadas no presente trabalho. Em (a) é mostrada a interpretação da linha 0231-1233_A; em (b), a interpretação da linha SPP992323; e em (c), a interpretação da linha 0221-6960. 1 = Embasamento, 2 = Sequência Rifte, 3 = Sequência Pós-Rifte, 4 = Sal, 5 = Albiano, $6=$ Cenomaniano-Maastrichtiano, 7 = Paleoceno-Oligoceno, 8 = Mioceno-Pleistoceno. . 43

Fig. 2. 9: Detalhes da interpretação estratigráfica e estrutural das linhas sísmicas mostradas na figuras 2.8a e 2.8b. Em (a) é possível observar uma falha normal com mergulho aparente no sentido NE afetando o Embasamento até a Sequência do CenomanianoMaastrichtiano, com rejeito diferencial (polígono amarelo), além de falhas normais com mergulho aparente para NE afetando somente a Sequência do Paleoceno-Oligoceno (polígono branco). Em (b), uma falha normal com mergulho aparente no sentido NE afeta o Embasamento com rejeito de 260 ms e as Sequências Rifte, Pós-Rifte e Sal com rejeito de até $30 \mathrm{~ms}$ (polígonos em vermelho). Em (c) ocorre uma falha normal com mergulho aparente no sentido NE afetando a Sequência do Sal (seta branca). 45

Fig. 2. 10: Mapas estruturais em tempo duplo para o topo: (a) do Embasamento; (b) da Sequência Rifte; (c) da Sequência Pós-Rifte; (d) do Sal; (e) da Sequência do Albiano; (f) da Sequência do Cenomaniano-Maastrichtiano; (g) da Sequência do PaleocenoOligoceno e (h) da Sequência do Mioceno-Pleistoceno.

Fig. 2. 11: Mapa dos principais elementos estruturais da região central da Bacia de Campos (áreas em vermelho são altos estruturais e áreas verdes são baixos estruturais). As linhas azuis representam as escarpas da Falha de Campos (linha azul contínua), que sofre escalonamento ao longo de fraturas de direção NW-SE (linhas pontilhadas em azul; dados compilados de Oliveira, 2015). Batimetria extraída de GEBCO (2013), imagem 


\section{APÊNDICE A}

Apêndice A.1: Seção sísmica 2D interpretada, segmento 0038-0241 .....................................60

Apêndice A.2: Seção sísmica 2D interpretada, segmento 0046-0118.....................................60

Apêndice A.3: Seção sísmica 2D interpretada, segmento 0046-0120.....................................61

Apêndice A.4: Seção sísmica 2D interpretada, segmento 0067-0489. ....................................61

Apêndice A.5. Seção sísmica 2D interpretada, segmento 0067-0497.....................................62

Apêndice A.6: Seção sísmica 2D interpretada, segmento 0067-0524....................................62

Apêndice A.7: Seção sísmica 2D interpretada, segmento 0203-0079....................................63

Apêndice A.8: Seção sísmica 2D interpretada, segmento 0214-0189.....................................63

Apêndice A.9: Seção sísmica 2D interpretada, segmento 0214-0191.....................................64

Apêndice A.10: Seção sísmica 2D interpretada, segmento 0214-0198....................................64

Apêndice A.11: Seção sísmica 2D interpretada, segmento 0214-0199...................................65

Apêndice A.12: Seção sísmica 2D interpretada, segmento 0221-6710..................................65

Apêndice A.13: Seção sísmica 2D interpretada, segmento 0228-0333 ...................................66

Apêndice A.14: Seção sísmica 2D interpretada, segmento 0228-0341................................... 66

Apêndice A.15: Seção sísmica 2D interpretada, segmento 0228-3624...................................67

Apêndice A.16: Seção sísmica 2D interpretada, segmento 0228-3636..................................67

Apêndice A.17: Seção sísmica 2D interpretada, segmento 0231-1218.................................. 68

Apêndice A.18: Seção sísmica 2D interpretada, segmento 0231-1233A.................................68

Apêndice A.19: Seção sísmica 2D interpretada, segmento 0231-1237...................................69

Apêndice A.20: Seção sísmica 2D interpretada, segmento 0231-1240....................................69

Apêndice A.21: Seção sísmica 2D interpretada, segmento 0231-1242................................... 70

Apêndice A.22: Seção sísmica 2D interpretada, segmento 0241-0655................................... 70

Apêndice A.23: Seção sísmica 2D interpretada, segmento 0241-0664................................... 71

Apêndice A.24: Seção sísmica 2D interpretada, segmento 0046-0122 .................................. 71 
Apêndice A.25: Seção sísmica 2D interpretada, segmento 0221-6870.................................. 71

Apêndice A.26: Seção sísmica 2D interpretada, segmento 0221-6960..................................72

Apêndice A.27: Seção sísmica 2D interpretada, segmento 0221-7000....................................72

Apêndice A.28: Seção sísmica 2D interpretada, segmento 0239-03651................................. 73

Apêndice A.29: Seção sísmica 2D interpretada, segmento SPP992323. ................................. 73

Apêndice A.30: Seção sísmica 2D interpretada, segmento 0228-3682 ..................................74

Apêndice A.31: Seção sísmica 2D interpretada, segmento 0239-0363................................... 75 


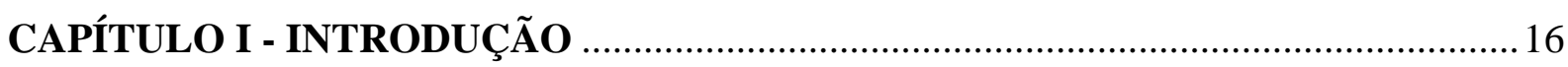

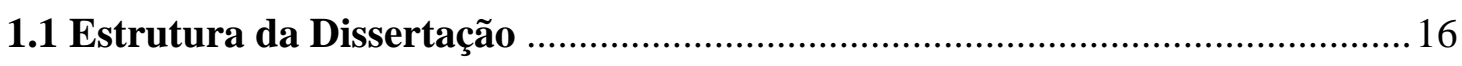

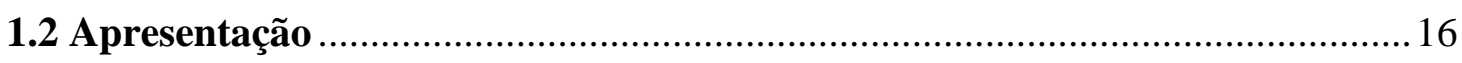

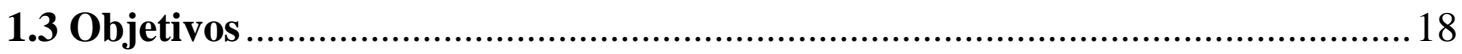

1.4 Localização e Vias de Acesso ………………………………………………... 19

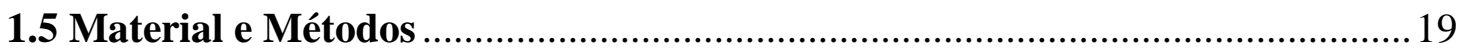

CAPÍTULO II - SIGNIFICADO E INFLUÊNCIA DO LINEAMENTO ALEGRE NA EVOLUÇÃO TECTÔNICA DA BACIA DE CAMPOS E MARGEM CONTINENTAL

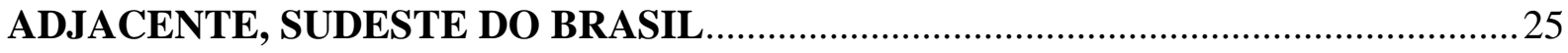

Resumo

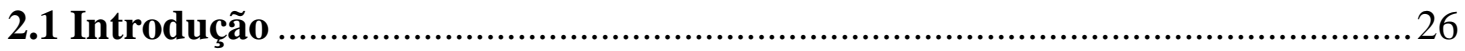

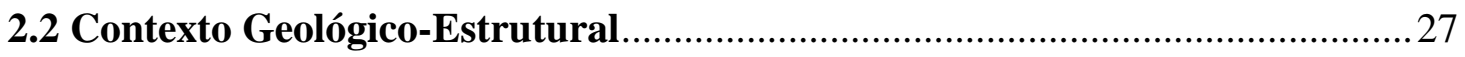

2.2.1 Características gerais da Bacia de Campos e do Embasamento Cristalino

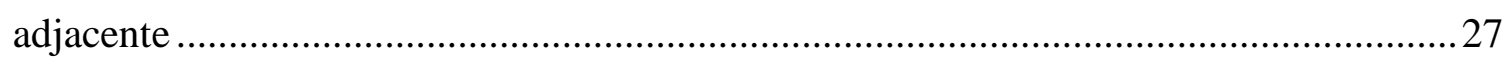

2.2.2 Evolução tectonoestrutural da área onshore ...............................................28

2.2.3 Evolução tectonoestrutural da área offshore - Bacia de Campos................... 30

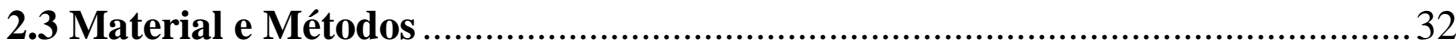

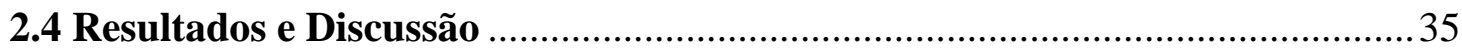

2.4.1 Análise estrutural em superfície .................................................................. 36

2.4.2 Análise estrutural em subsuperfície..............................................................42

2.5 Integração dos Dados de Superfície e Subsuperfície ………………………….... 48

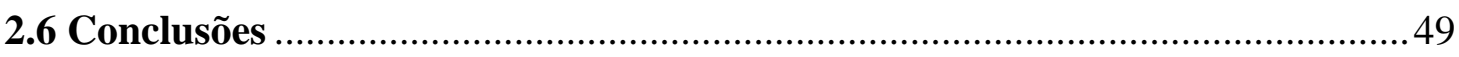

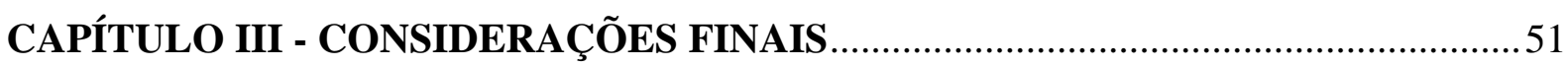

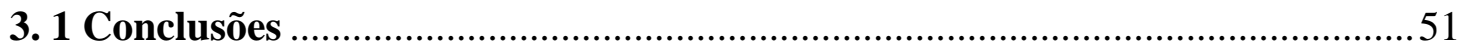

3.2 Sugestões para Trabalhos Futuros.............................................................52

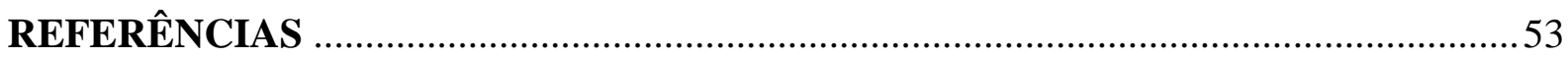


APÊNDICE A - SEÇÕES SÍSMICAS 2D INTERPRETADAS

.60 


\section{CAPÍTULO I - INTRODUÇÃO}

\subsection{Estrutura da Dissertação}

Esta dissertação de mestrado é apresentada em formato de artigo científico, dividida em três capítulos e um apêndice. O capítulo I apresenta o tema principal da dissertação e um breve contexto geológico-estrutural da região estudada, os objetivos, a área de estudo e os materiais e métodos. O capítulo II, redigido no formato de artigo, apresenta o estudo intitulado "Controle estrutural na evolução tectônica da porção central da Bacia de Campos e área continental adjacente, Sudeste do Brasil" que será submetido no Journal of South American Earth Science. O capítulo III sintetiza as principais conclusões da pesquisa. No Apêndice A são apresentadas as seções sísmicas 2D interpretadas neste estudo.

\subsection{Apresentação}

A dissertação traz como objeto principal o estudo de estruturas geológicas presentes no Embasamento e sua atuação na evolução da bacia costeira adjacente. $\mathrm{O}$ desenvolvimento de bacias de margem passiva está relacionado a diversos fatores, como a taxa de estiramento litosférico, a temperatura da litosfera, a espessura crustal, o estado de hidratação do manto litosférico e a estruturação litosférica e zonas de fraquezas preexistentes (Davison, 1997). As zonas de fraquezas preexistentes herdadas do Embasamento possuem papel importante no desenvolvimento da margem continental (Dunbar \& Sawyer, 1989). Geralmente são originadas por eventos tectônicos antigos e podem agir como zonas de instabilidades, sendo reativadas durante a evolução geológica sob a forma de falhas com as mesmas orientações (Davison, 1997). O Embasamento, tanto da bacia, quanto da área continental adjacente, exerce influência na estruturação da bacia, controlando a localização dos principais depocentros e as taxas de subsidência, e influenciando na evolução tectono-sedimentar (Michon \& Sokoutis, 2005; Wilson, 2005).

A área continental da região estudada está situada entre a região Sul do Estado do Espírito Santo e Norte do Estado do Rio de Janeiro e, na região oceânica, na porção central da Bacia de Campos. $\mathrm{O}$ arcabouço geológico aflorante na área continental estudada é constituído principalmente por rochas pré-cambrianas e rochas ígneas intrusivas cambrianas, vinculadas ao 
ciclo orogênico Brasiliano/Pan-Africano (entre ca. 670 Ma a 40 Ma; e.g., Almeida et al., 1981). As principais estruturas geológicas formadas nesse evento possuem direções que variam de NESW a N-S, compostas por empurrões tectônicos e zonas de cisalhamento transcorrentes a transpressivas de cinemática destral (sensu Heilbron et al., 2004; Pedrosa Soares \& Wiedemann-Leonardos, 2000; Pedrosa Soares et al., 2007). Na faixa litorânea, ocorrem sedimentos do Grupo Barreiras (Arai, 2006) ou Formação Barreiras (Morais et al., 2006), além dos depósitos aluvio-coluvionares, fluviais e litorâneos do Quaternário (Silva et al., 2004). Na porção oceânica, o Embasamento é recoberto pelas sequências sedimentares da Bacia de Campos, a principal produtora de petróleo do Brasil (ANP, 2014). Ela cobre uma área de cerca de $100.000 \mathrm{~km}^{2}$, dos quais apenas $500 \mathrm{~km}^{2}$ estão emersos. O Alto de Vitória limita a Bacia de Campos ao Norte, separando-a da bacia do Espírito Santo, e o Alto de Cabo Frio a limita ao Sul, separando-a da Bacia de Santos (Schaller, 1973; Milani et al., 2000). A Bacia de Campos está vinculada a mecanismos de distensão litosférica que conduziram à ruptura do paleocontinente Gondwana e à formação do Oceano Atlântico Sul (e.g., Chang et al., 1992; Cainelli \& Mohriak, 1999). O registro geológico da Bacia de Campos registra três ambientes deposicionais principais, com uma sequência clástica não marinha, uma sequência evaporítica e uma sequência clástica parálica e marinha franca (Ponte \& Asmus, 1978).

O papel das estruturas herdadas do ciclo orogênico Brasiliano/Pan-Africano na estruturação das bacias da margem Sul e Sudeste do Brasil é bem difundido na literatura geológica (e.g. Schaller, 1973; Ponte \& Asmus, 1978; Ojeda, 1982; Dias et al., 1987; Guardado et al., 1989; Chang et al., 1992; Fetter, 2009). Segundo esses autores, a estruturação do Embasamento de direção geral NE-SW, representada pela foliação regional e por zonas de cisalhamento neoproterozóicas, controlou os principais elementos estruturais e os depocentros da Bacia de Campos. Entretanto, ainda permanecem diversos questionamentos sobre a presença de estruturas de direção NW-SE e NNW-SSE no Embasamento aflorante e sua influência no desenvolvimento das bacias costeiras. Na região norte do Espírito Santo, Fetter (2009) e Novais et al. (2004) mostram que a estruturação NNW-SSE controla os principais depocentros da fase rifte e a migração de hidrocarbonetos na Bacia de Campos. Cobbold et al. (2001) e Meisling et al. (2001) identificaram falhas de transferência envolvendo o Embasamento, associadas a processos de rifteamento ortogonal e oblíquo nas Bacias de Campos e Santos. Segundo esses autores, os blocos do rifte sofreram escalonamento a partir de falhas NW-SE, segmentando os depocentros do rifte e a margem continental em sub-bacias. Souza et al. (2009) também identificaram estruturas de direção NW-SE transversais e subtransversais à costa brasileira, evidenciando que essas falhas podem controlar depocentros da Bacia de Santos. 
$\mathrm{Na}$ área continental adjacente à Bacia de Campos são comumente observadas estruturas geológicas de direção NNW-SSE, que ocorrem ora sob a forma de conjuntos de lineamentos subparalelos, ora como feições singulares. Na região sul do Estado do Espírito Santo ocorre um importante lineamento, denominado no presente trabalho de Lineamento Alegre. Essa feição atravessa toda a região sul do estado e se projeta para a área oceânica até importantes campos petrolíferos, como os campos de Enchova e Bonito (Fig. 1.1). Portanto, o objetivo desta pesquisa foi identificar a influência do Lineamento Alegre na porção central da Bacia de Campos e na área continental adjacente, buscando elucidar o possível controle estrutural que essa feição possa ter exercido durante a evolução geológica.
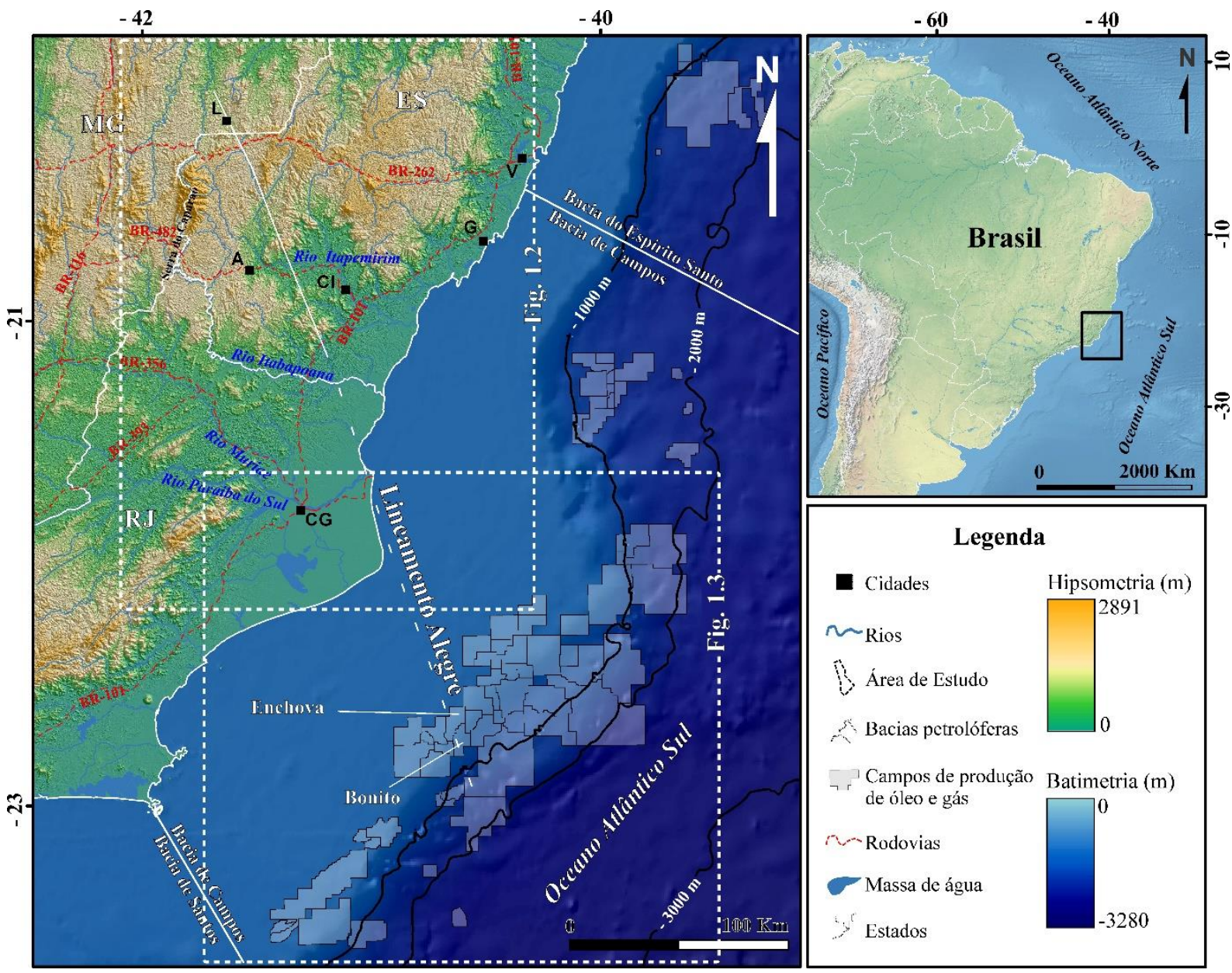

Fig. 1. 1: Mapa de localização da área de estudos. Cidades: $A=$ Alegre, $C I=$ Cachoeiro de Itapemirim, $C G=$ Campos dos Goytacazes, G = Guarapari, L = Lajinha, V = Vitória. Estados: ES = Espírito Santo, RJ = Rio de Janeiro, MG = Minas Gerais. Rodovias e drenagens extraídos de Geobases (2002), batimetria extraída de GEBCO (2013), imagem ASTER GDEM (Advance Space Borne Thermal Emission and Reflection Radiomete-Global Digital Elevation Model Shuttle Radar Topography Mission) de ERSDAC (2013), campos de produção de óleo e gás de BDEP (2013).

\subsection{Objetivos}


O objetivo geral desta dissertação foi a identificação da influência do Lineamento Alegre na porção central da Bacia de Campos e na área continental adjacente, buscando a relação do possível controle estrutural que essa feição possa ter exercido durante a evolução geológica da margem continental.

Para tanto, definem-se, como objetivos específicos:

- A caracterização geológico-estrutural da área continental utilizando técnicas de SIG (Sistema de Informações Geográficas) e levantamento de campo;

- A caracterização estrutural da Bacia de Campos por meio de poços e dados geofísicos (sísmica 2D);

- A correlação das estruturas analisadas na porção continental com a porção oceânica.

\subsection{Localização e Vias de Acesso}

A área de estudo compreende, em sua porção continental, a região sul do Estado do Espírito Santo, parte do norte do Estado do Rio de Janeiro e uma pequena porção no extremo sudeste do Estado de Minas Gerais, com continuidade para a parte central da Bacia de Campos. Os limites da área de estudo foram definidos considerando-se a localização geográfica do Lineamento Alegre em sua porção continental e sua projeção para a área oceânica (Fig. 1.1).

A região possui importantes rodovias federais (BR), como as 101, 262 e 482 (Fig. 1.1) que, juntamente com as estradas estaduais, municipais e vicinais, serviram de apoio aos trabalhos de campo. Na hidrografia, os Rios Paraíba do Sul, Muriaé, Itabapoana e Itapemirim se destacam como os principais da região. O relevo é bastante acidentado, sendo que a variação de altitude parte de 0 metros próximo à linha de costa até 2.891 metros no Pico da Bandeira, Serra do Caparaó (IBGE, 2005). A fisiografia submarina da região da Bacia de Campos é constituída pela plataforma continental, talude continental e o Platô de São Paulo (Palma, 1984). A batimetria da região possui variações de 0 metros de profundidade na linha de costa e pode chegar até 3.280 metros em regiões de águas profundas (Fig. 1.1; GBCO, 2013).

\subsection{Material e Métodos}

A análise estrutural consistiu em observações realizadas em superfície, por meio de dados de sensoriamento remoto e aquisição de dados estruturais em campo, e em subsuperfície, por meio da análise de perfis sísmicos de reflexão e correlação com perfis geofísicos de poços. 
A análise dos dados de sensoriamento remoto foi realizada em ambiente SIG (Sistema de Informações Geográficas), com o auxílio do software ArcGis v. 10.2, reunindo os seguintes dados: mapas topográficos em escala 1:50.000 do IBGE (Instituto Brasileiro de Geografia e Estatística), arquivos vetoriais de dados culturais, geográficos, topográficos e hidrográficos (Geobases, 2002), imagens orbitais ASTER GDEM (Advance Space Borne Thermal Emission and Reflection Radiomete-Global Digital Elevation Model Shuttle Radar Topography Mission) de ERSDAC (2013), e fotos aéreas cedidas pelo Instituto Estadual do Meio Ambiente e Recursos Hídricos (IEMA, 2007). Foram utilizados também mapas geológicos preexistentes, como a Folha Cachoeiro de Itapemirim SF 24-V-A Escala 1:250.000 (Vieira, 1997), a Folha Vitória SF 24, Escala 1:1000.000 (Silva et al., 2004) e o Mapa Geológico do Espírito Santo em escala 1:400.000 (Vieira et al., 2014).

Os critérios definidos para o traçado dos lineamentos se basearam em expressões de elementos topográficos retilíneos do relevo, tais como linhas ou segmentos de escarpas, alinhamentos de cristas, vales, trechos de rios e lagos, linhas de costa alongadas, depressões alongadas e outras, como feições lineares que separam terrenos de diferentes texturas e alinhamento de vegetação (O'Leary et al., 1976). Liu (1970) mostra ainda que os lineamentos são quase sempre correlacionados estruturalmente com fraturas, falhas, zonas de falhas, zonas de cisalhamento e juntas, evidenciando sua importância na interpretação estrutural de determinada área.

O levantamento de campo englobou a análise geométrica e cinemática das feições estruturais planares e lineares, como juntas, falhas, estrias e foliações, nos entornos do Lineamento Alegre, buscando a correlação estrutural das estruturas de campo com as observadas em sensoriamento remoto. O banco de dados estruturais de campo contempla 385 afloramentos, agrupados posteriormente em dois conjuntos. O primeiro conjunto inclui todos os afloramentos que se encontram em uma distância de $40 \mathrm{~km}$ do traçado do lineamento (buffer 40 km; Fig. 1.2), enquanto o segundo inclui os afloramentos que ocorrem a uma distância de 3 km (buffer $3 \mathrm{~km}$; Fig. 1.2). Essa divisão possui a finalidade de evidenciar o controle das estruturas atuantes na região de influência do Lineamento Alegre em relação à estruturação regional. Foram gerados estereogramas em projeção de hemisfério inferior em rede de igual área utilizando o software OpenStereo (Grohmann et al., 2011). A análise do stress tectônico foi realizada pela inversão de dados cinemáticos de falhas pelo método dos diedros retos (Angelier \& Mechler, 1977) no software WinTensor v. 5.05 (Delvaux \& Sperner, 2003). 


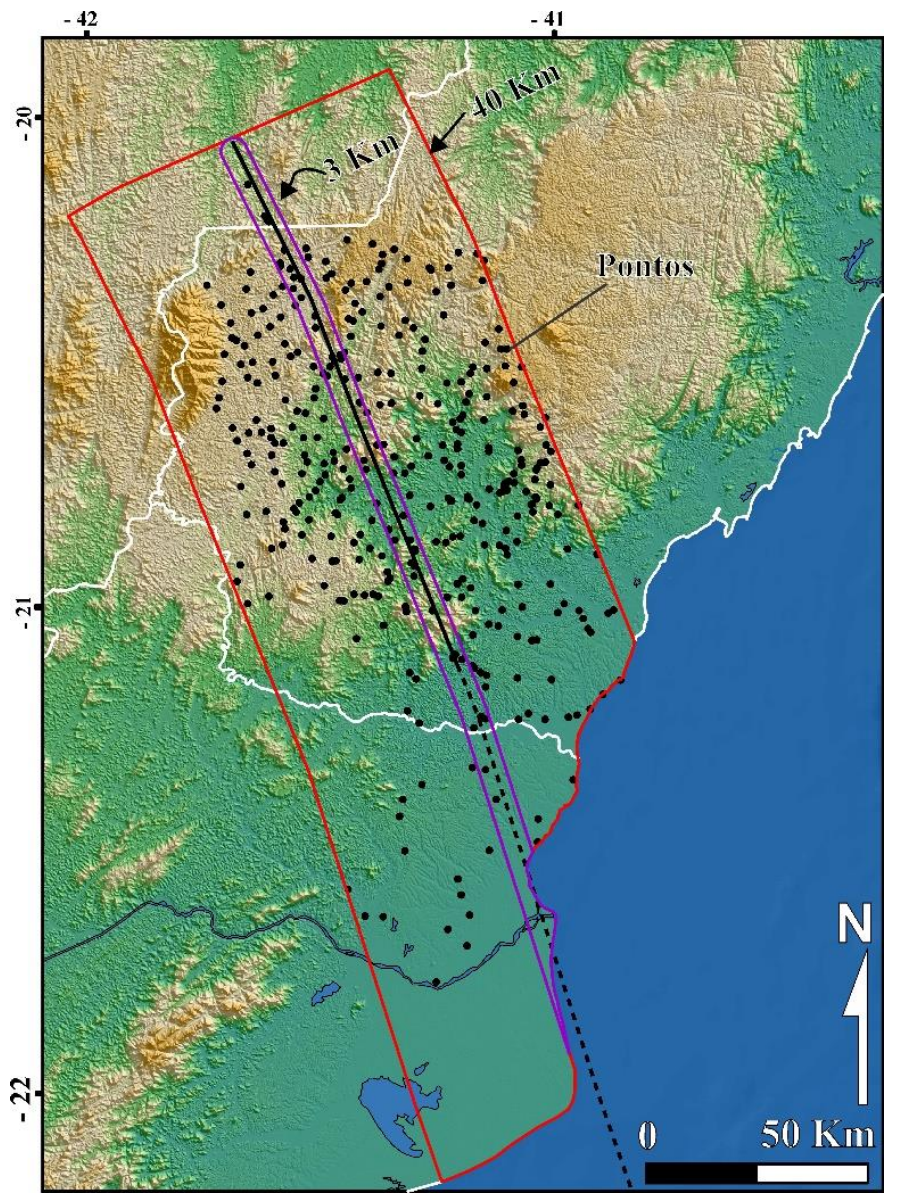

Fig. 1. 2: Mapa de localização dos afloramentos visitados. Drenagem extraída de Geobases (2002), imagem ASTER GDEM (Advance Space Borne Thermal Emission and Reflection Radiomete-Global Digital Elevation Model Shuttle Radar Topography Mission) de ERSDAC (2013). Os polígonos representam o buffer de $40 \mathrm{Km}$ (vermelho) e o buffer de $3 \mathrm{Km}$ (roxo).

A análise de subsuperfície foi realizada pela interpretação estrutural de 31 linhas sísmicas 2D (3.051,544 Km) e 13 poços de exploração e produção de petróleo, fornecidos pela Agência Nacional do Petróleo (ANP; Fig. 1.3, Apêndice A), pela política de gratuidade de dados para pesquisa em universidades públicas brasileiras. As informações lito e cronoestratigráficas obtidas a partir dos poços, tais como discordâncias e limites entre formações (marcadores estratigráficos; Fig. 1.4), juntamente com os perfis geofísicos dos poços (raios gama, sônico e densidade), foram utilizados para definição das idades dos refletores sísmicos e da correlação lateral entre as linhas. Os poços (em profundidade) foram amarrados com as linhas sísmicas (em tempo), utilizando-se a velocidade intervalar registrada nos perfis sônicos em microssegundo por pé (ms/feet) para cada poço. Dessa forma, o topo do Embasamento foi calibrado com o topo dos basaltos da Formação Cabiúnas; o topo da Sequência Rifte, com a Formação Coqueiros; o topo da Sequência Pós-Rifte, com a discordância pré-evaporítica; o topo do Sal, com a Formação Retiro; o topo do Albiano, com a Formação Outeiro; o topo da Sequência Cenomaniano-Maastrichtiano, com o Membro 
Tamoios da Formação Ubatuba; o topo da Sequência Paleoceno-Oligoceno, com o Membro Siri da Formação Emborê; e o topo da Sequência Mioceno-Pleistoceno, com o Fundo do Mar (Fig. 1.4).

Os horizontes sísmicos foram interpretados em todas as 31 linhas sísmicas 2D em tempo duplo (TWT), obtendo-se uma malha de pontos para cada horizonte interpretado. Foram geradas superfícies 3D para cada horizonte a partir da interpolação dos dados pontuais delimitados por um polígono (Fig. 1.3) pelo método de interpolação de mínima curvatura. A delimitação do polígono baseou-se na delimitação da área onde houve o maior adensamento de linhas sísmicas, buscando-se a maior confiabilidade dos dados. Dessa forma, foram obtidas superfícies em tempo duplo para o topo: (i) do Embasamento; (ii) da Sequência Rifte; (iii) da Sequência Pós-Rifte; (iv) do Sal; (v) da Sequência Albiana; (vi) da Sequência CenomanianaMaastrichtiana; (vii) da Sequência do Paleoceno-Oligoceno; e (viii) da Sequência do MiocenoPleistoceno. 


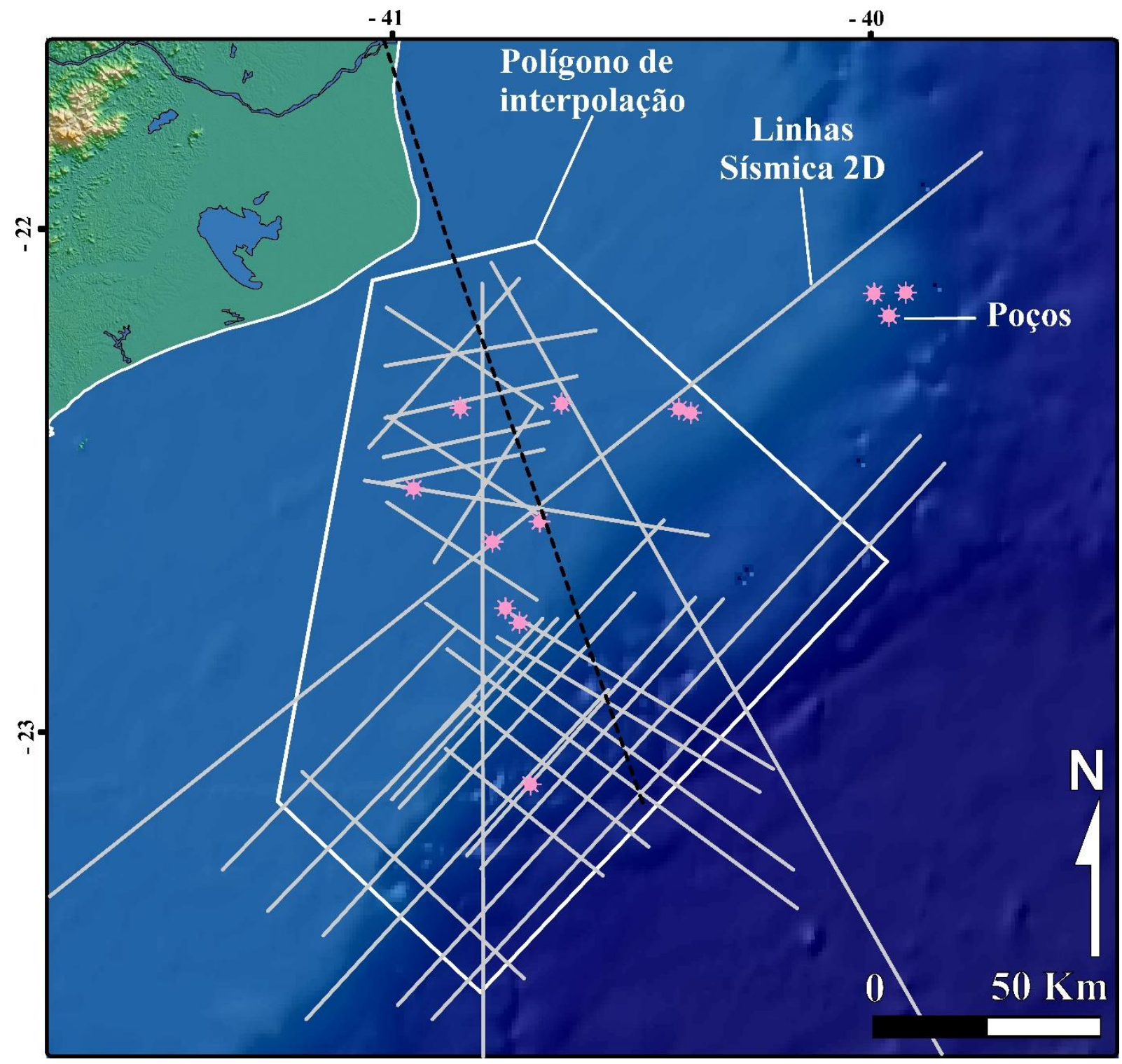

Fig. 1. 3: Mapa de localização dos dados utilizados em subsuperfície. Drenagem extraída de Geobases (2002), batimetria extraída de GEBCO (2013), imagem ASTER GDEM (Advance Space Borne Thermal Emission and Reflection Radiomete-Global Digital Elevation Model Shuttle Radar Topography Mission) de ERSDAC (2013). As linhas representam o polígono de interpolação (branco) e as linhas sísmicas (cinza). Os pontos em rosa representam os poços. 


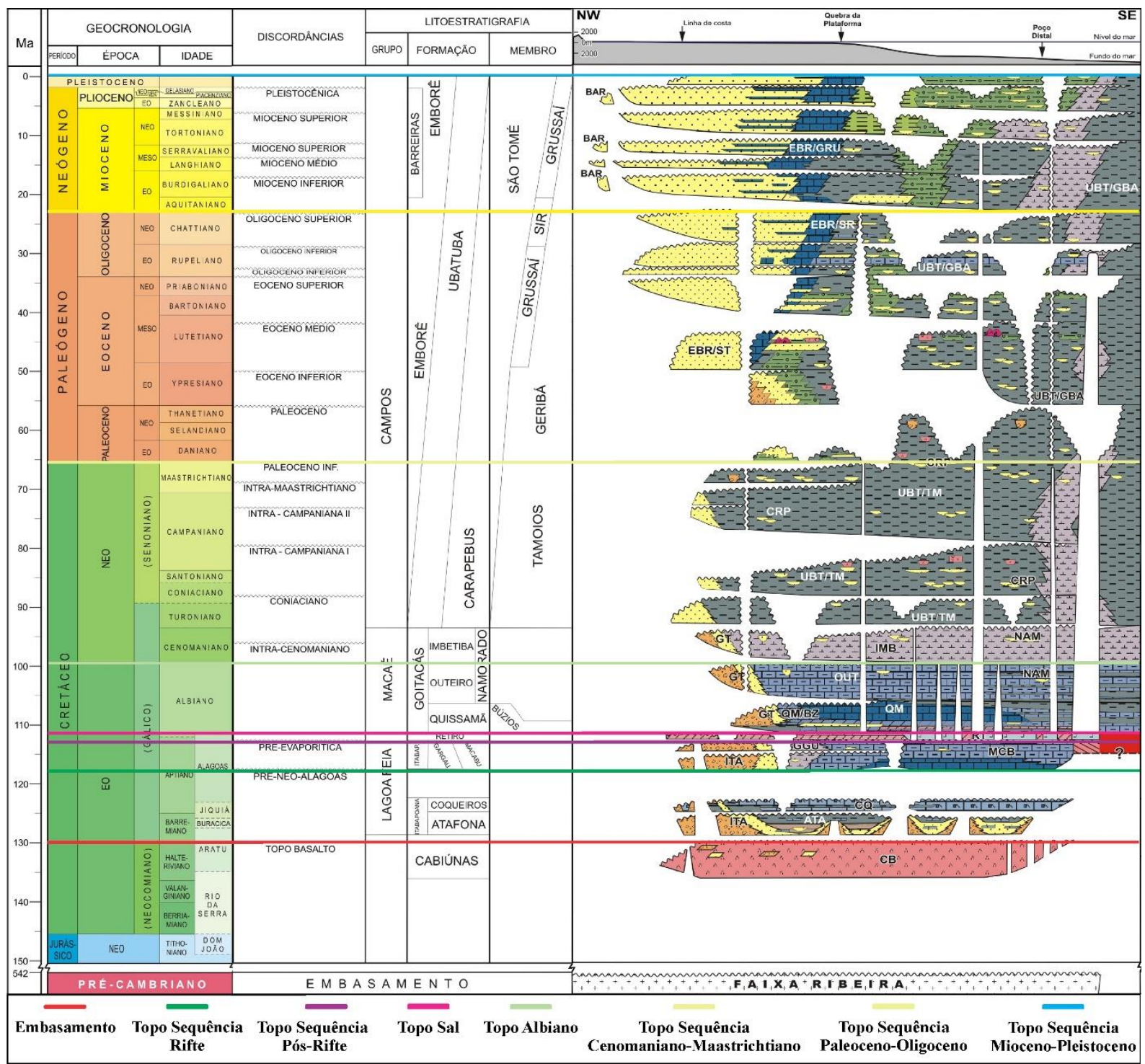

Fig. 1. 4: Coluna cronoestratigráfica da Bacia de Campos e horizontes interpretados (simplificado de Winter et al. 2007). 


\title{
CAPÍTULO II
}

\section{SIGNIFICADO E INFLUÊNCIA DO LINEAMENTO ALEGRE NA EVOLUÇÃO TECTÔNICA DA BACIA DE CAMPOS E MARGEM CONTINENTAL ADJACENTE, SUDESTE DO BRASIL}

\author{
Salomão Silva Calegari a , Mirna Aparecida Neves ${ }^{\text {b }}$, Felipe Guadagnin ${ }^{\text {c }}$, George Sand \\ França $^{\mathrm{d}}$, Maria Gabriela Castillo Vincentelli ${ }^{\mathrm{e}}$
}

\footnotetext{
a Programa de Pós-Graduação em Geologia, Universidade de Brasília, Brasília, Brasil

${ }^{\mathrm{b}}$ Departamento de Geologia, Universidade Federal do Espírito Santo, Alegre, Brasil

${ }^{c}$ Campus Caçapava do Sul, Universidade Federal do Pampa, Caçapava do Sul, Brasil

${ }^{\mathrm{d}}$ Observatório Sismológico, Universidade de Brasília, Brasília, Brasil

e Laboratório de Integração de Dados Sísmicos e Geológicos, Universidade Estadual Paulista, Rio Claro, Brasil
}

\section{Resumo}

O desenvolvimento e o arcabouço estrutural das bacias da margem leste do continente SulAmericano estão intimamente associados ao arcabouço tectônico e às heterogeneidades crustais herdadas do Embasamento Pré-cambriano. Contudo, o papel de estruturas de direções NW-SE e NNW-SSE presentes no Embasamento aflorante e sua influência na evolução dessas bacias ainda não receberam atenção necessária. Na região continental adjacente à Bacia de Campos, observa-se uma feição geológica de direção NNW-SSE denominada, no presente trabalho, de Lineamento Alegre. O objetivo principal deste trabalho é o estudo da constituição deste Lineamento e de sua influência na evolução tectônica da porção central da Bacia de Campos e na área continental adjacente, abrangendo o Sul do Estado do Espírito Santo e o extremo Norte do Estado do Rio de Janeiro. A investigação da área continental foi realizada com dados de sensoriamento remoto e observações de campo e, em subsuperfície, por meio da interpretação de seções sísmicas 2D e correlação com perfis geofísicos de poços. A integração dos dados revelou que, tanto em área continental quanto em área oceânica, o Lineamento Alegre constitui um conjunto de fraturas originadas no Cambriano, que foram reativadas no Cretáceo Inferior e 
entre o Paleoceno e Oligoceno sob a forma de falhas normais de direção NNW-SSE. Na bacia de Campos, essas estruturas atuaram na compartimentação do Baixo Corvina-Parati durante a fase rifte, com reativações no início do Paleoceno até o final do Oligoceno, resultando em um complexo sistema junto às falhas de transferência NW-SE e às falhas NE-SW.

Palavras-chave: estruturas rúpteis, reativação, Lineamento Alegre.

\subsection{Introdução}

Durante a evolução geológica e estrutural de bacias sedimentares do sistema rifte-drifte, as heterogeneidades geológicas e estruturais do Embasamento exerceram influência na estruturação da bacia, controlando a localização dos principais depocentros, as taxas de subsidência e a evolução tectono-sedimentar (Michon \& Sokoutis, 2005; Wilson, 2005).

O desenvolvimento e o arcabouço estrutural das bacias da margem leste do continente Sul-Americano estão intimamente associados à trama estrutural e às heterogeneidades crustais herdadas do Embasamento cristalino (e.g., Schaller, 1973; Ponte \& Asmus, 1978, Dias et al., 1987; Guardado et al., 1989; Davison, 1997, Fetter, 2009). Na região Nordeste do Brasil, os trabalhos de Bezerra \& Vita-Finzi (2000) e Bezerra et al. (2014) mostraram a importância da reativação das zonas de cisalhamento dúctil do Embasamento Pré-cambriano no padrão e localização da sedimentação e na topografia da margem continental até o Quaternário.

Nas bacias da margem Sul e Sudeste do Brasil, o controle estrutural exercido pelo Embasamento é feito principalmente por estruturas de direção geral NE-SW a NNE-SSW, paralelas a subparalelas à foliação regional e às zonas de cisalhamento neoproterozóicas (Ojeda, 1982; Chang et al., 1992). Porém, a presença de estruturas de direções NW-SE e NNW-SSE no Embasamento aflorante e sua influência na evolução estrutural das bacias marginais são pouco entendidas. Os autores que estudaram essas feições na região Sudeste do Brasil (e.g., Novais et al., 2004; Fetter, 2009) relatam o controle dos depocentros da fase rifte nas bacias do Espírito Santo e de Campos por estruturas NNW-SSE do Lineamento Colatina, aflorantes no Norte do Estado do Espírito Santo. Cobbold et al. (2001) e Meisling et al. (2001) atribuem às estruturas de direção NW-SE o papel de zonas de transferência que controlam a variação da vergência do mergulho dos blocos da fase rifte na Bacia de Campos. As falhas de transferência podem ser controladas por anisotropias pré-existentes, assumindo um papel importante na arquitetura dos riftes e das bacias extensionais (Gibbs, 1984). 
$\mathrm{Na}$ área continental emersa adjacente à Bacia de Campos são comumente observadas estruturas geológicas de direções NW-SE e NNW-SSE, visualizadas tanto em imagens de sensores remotos e aerogeofísicas quanto em campo. Essas estruturas ocorrem ora sob a forma de conjuntos de lineamentos subparalelos, ora como feições singulares. Na região sul do Estado do Espírito Santo há um lineamento contínuo e bem marcado de direção NNW-SSE, denominado neste trabalho de Lineamento Alegre. Essa feição atravessa toda a região sul do estado e sua projeção para a área oceânica atinge importantes campos petrolíferos, como os de Enchova e Bonito (Fig. 2.1). Dessa forma, o objetivo desta pesquisa foi identificar a influência do Lineamento Alegre na porção central da Bacia de Campos e na área continental adjacente, buscando elucidar o possível controle estrutural que essa feição possa ter exercido durante a evolução geológica regional.

\subsection{Contexto Geológico-Estrutural}

2.2.1 Características gerais da Bacia de Campos e do Embasamento Cristalino adjacente

O Embasamento Cristalino da área estudada é constituído principalmente por rochas pré-cambrianas (Fig. 2.1), incluindo ortognaisses e paragnaisses altamente deformados, alguns do Paleoproterozoico, mas a maioria do Neoproterozoico, e granitoides do Neoproterozoico (Silva et al., 2004). As rochas cambrianas são granitoides oriundos de magmatismo calcioalcalino tipo I, pós-colisional (Pedrosa-Soares et al., 2007; Silva et al., 2004). Na faixa litorânea, ocorrem sedimentos de idade mio-pliocênica do Grupo Barreiras (Arai, 2006) ou Formação Barreiras (Morais et al., 2006), além de depósitos aluvio-coluvionares, fluviais e litorâneos do Quaternário (Silva et al., 2004).

Na porção oceânica, o Embasamento é recoberto pelas sequências sedimentares da Bacia de Campos, a principal produtora de petróleo do Brasil (ANP, 2014). Ela cobre uma área de cerca de $100.000 \mathrm{~km}^{2}$, dos quais apenas $500 \mathrm{~km}^{2}$ estão emersos. O Alto de Vitória limita a Bacia de Campos ao Norte, separando-a da bacia do Espírito Santo, e o Alto de Cabo Frio a limita ao Sul, separando-a da Bacia de Santos (Schaller, 1973; Milani et al., 2000). O registro geológico da bacia de Campos registra três ambientes deposicionais principais, com uma sequência clástica não marinha, uma sequência evaporítica e uma sequência clástica parálica e marinha franca (Ponte \& Asmus, 1978).

A evolução tectonoestrutural das áreas onshore e offshore é detalhada nos itens $2.2 .2 \mathrm{e}$ 2.2.3. 


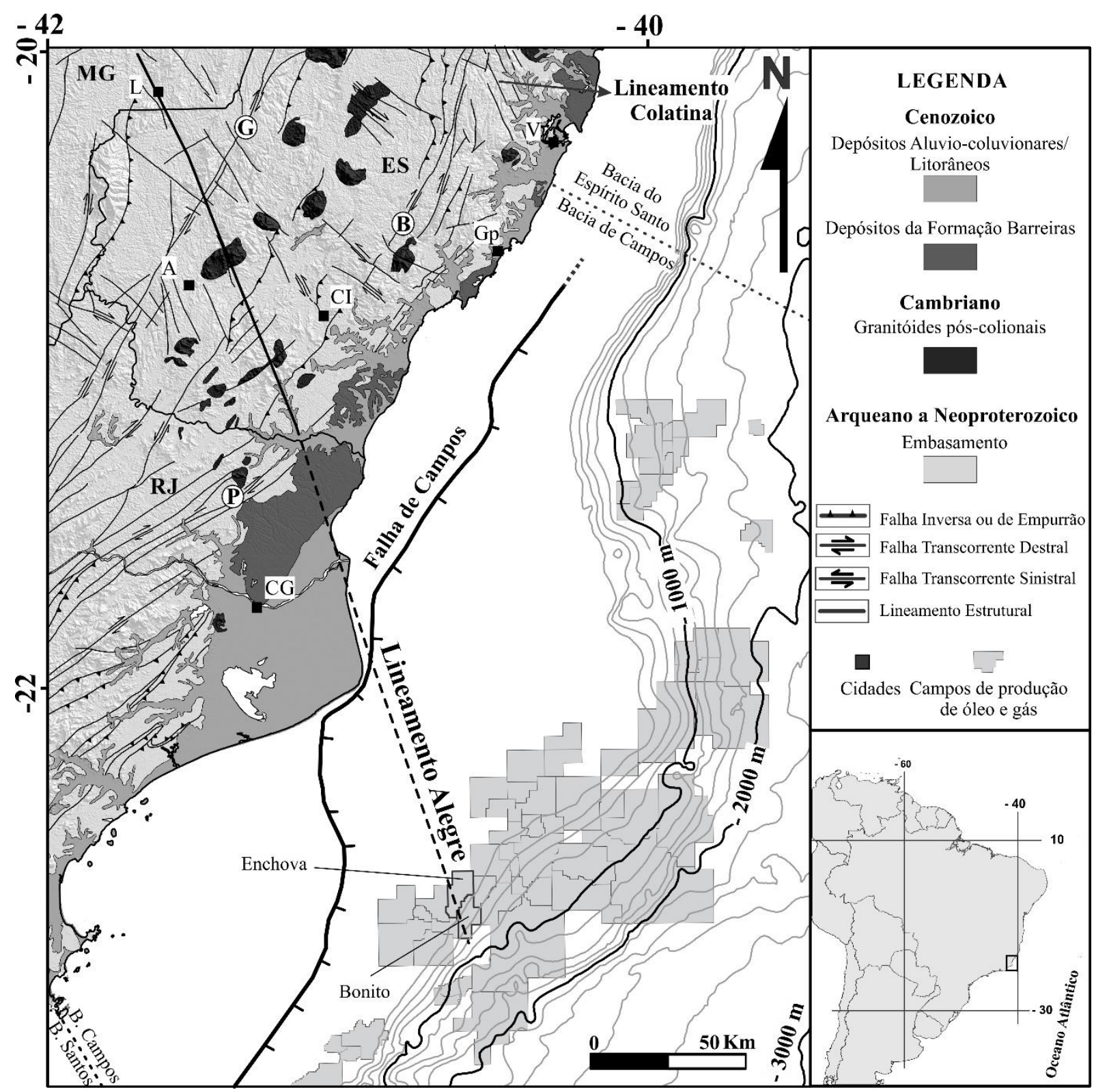

Fig. 2. 1: Arcabouço geológico da área de ocorrência do Lineamento Alegre na porção continental e sua projeção para a região oceânica, onde se localizam os principais campos petrolíferos brasileiros. Geologia simplificada de Silva et al. (2004), batimetria extraída de GEBCO (2013), imagem ASTER GDEM (Advance Space Borne Thermal Emission and Reflection Radiometer-Global Digital Elevation Model Shuttle Radar Topography Mission) de ERSDAC (2013), Falha de Campos de Guardado et al. (2000), campos de produção de óleo e gás de BDEP (2013), zonas de cisalhamento de Alkmim et al. (2006). Principais zonas de cisalhamento: $\mathrm{G}=$ Guaçuí, $\mathrm{B}=\mathrm{Batatal}, \mathrm{P}=$ Além Paraíba. Cidades: $\mathrm{A}=$ Alegre, $\mathrm{CI}=$ Cachoeiro de Itapemirim, $\mathrm{CG}=$ Campos dos Goytacazes, GP = Guarapari, L = Lajinha, V = Vitória. Estados: ES = Espírito Santo, RJ = Rio de Janeiro, MG = Minas Gerais.

\subsubsection{Evolução tectonoestrutural da área onshore}

O Lineamento Alegre ocorre na porção leste do Brasil, na transição entre as Faixas Móveis Araçuaí e Ribeira (sensu Heilbron et al., 2004; Pedrosa-Soares \& WiedemannLeonardos, 2000). O limite entre as Faixas Ribeira e Araçuaí ocorre próximo ao paralelo $21^{\circ} \mathrm{S}$ (Pedrosa-Soares \& Wiedemann-Leonardos, 2000), divisão relacionada principalmente a uma 
mudança significativa na direção das foliações, que infletem de NE-SW (Faixa Ribeira) para NNE-SSW a N-S (Faixa Araçuaí) (Pedrosa-Soares et al., 2001; Heilbron et al., 2004).

A origem dessa província tectônica relaciona-se com a colisão continental do ciclo orogênico Brasiliano/Pan-Africano, entre o Neoproterozóico e o Paleozóico Inferior (entre ca. 670 Ma a 490 Ma; e.g., Almeida et al., 1981). Os processos orogênicos do ciclo Brasilino/PanAfricano tiveram clímax entre $670 \mathrm{Ma}$ e $550 \mathrm{Ma}$, associados à subducção da litosfera oceânica e ao fechamento de uma bacia oceânica, com intenso tectonismo, metamorfismo de alto grau e magmatismo granítico (e.g., Trompette et al., 1993; Pedrosa-Soares et al., 1999, 2001, 2007, 2011; Pedrosa-Soares \& Wiedemann-Leonardos, 2000; Wiedemann et al., 2002; De Campos et al., 2004; Heilbron et al., 2004; Alkmim et al., 2006, 2007; Karniol \& Machado, 2010). Em ambas as faixas móveis ocorrem zonas de cisalhamento tardias, como as Zonas de Cisalhamento Guaçuí, Batatal e Além Paraíba, que se formaram em estágio posterior à propagação das frentes de empurrão, provavelmente no intervalo entre 560 e 535 Ma (Fig. 2.1; Alkmim et al., 2006). As últimas manifestações magmáticas e deformacionais deste ciclo ocorreram entre $510 \mathrm{Ma}$ e $490 \mathrm{Ma}$, com o estabelecimento do Supercontinente Gondwana Ocidental.

Após a aglutinação do Supercontinente Gondwana, processos de acresção crustal ao longo do Paleozoico e parte do Mesozoico levaram à formação do Supercontinente Pangea. Contudo, no Mesozoico, iniciou-se a fragmentação do Pangea, cuja evolução define a configuração dos continentes e oceanos atuais (e.g., Brito Neves, 2002; Veevers, 2004; Stampfli et al., 2013; Torsvik \& Coock, 2013).

Os eventos extensionais ligados à ruptura do Gondwana definiram os traços gerais da margem continental do Sudeste do Brasil. Tais eventos foram precedidos por uma fase de anomalia termal durante o Jurássico, que evoluiu para a fase rifte no Cretáceo Inferior, quando atuou um eixo distensivo de direção NW-SE (Chang et al., 1992) a WNW-ESE, entre 137 e $122 \mathrm{Ma}$ (Stanton et al., 2010).

De acordo com Riccomini et al. (1989), entre o final do Paleoceno e final do Oligoceno, o esforço distensivo atuou na região Sudeste do Brasil com direção NW-SE a NNW-SSE, dando origem ao Rifte Continental do Sudeste do Brasil (RCSB). Ao longo dessa feição ocorrem bacias sedimentares continentais alinhadas na direção NE-SW como, por exemplo, as bacias de São Paulo, Taubaté e Resende, nos Estados de São Paulo e Rio de Janeiro (e.g., Riccomini et al., 1989; Almeida \& Carneiro, 1998; Zalán \& Oliveira, 2005).

Vários pesquisadores consideram que, a partir do Mioceno Médio, houve a mudança do tensor distensivo para outro transcorrente, o que seria o principal evento neotectônico da região Sudeste do Brasil (Hasui, 1990). O tensor principal, de cinemática transcorrente destral, seria 
consequência da imposição de um binário de direção E-W imposto pela rotação da Placa SulAmericana para Oeste. Muitas discussões ainda existem sobre a existência de um ou mais eventos neotectônicos no Brasil e suas idades, mas a transcorrência destral E-W é identificada em muitos locais da região Sudeste (e.g. Silva e Mello, 2011; Riccomini, 1997).

Como consequência da evolução estrutural, a área é bem marcada pelas zonas de cisalhamento tardias do Ciclo Brasiliano, transcorrentes a transpressivas predominantemente destrais, de direção geral NE-SW com inflexão para N-S (Alkmim et al., 2006; Cunningham et al. 1998). No entanto, a origem e constituição da estruturação NW-SE e NNW-SSE ainda não está estabelecida para a região. Silva et al. (2004) e Vieira et al. (2014) relacionam as estruturas de direção NW-SE a zonas de cisalhamento sinistrais e falhas ou fraturas. Um exemplo é o Lineamento Colatina (Fig. 2.1), interpretado como um feixe de fraturas de direção NNW-SSE (Vieira et al., 2014). Valente (2009) e Novais et al. (2004) discutem a relação entre os diques que ocorrem na região do Lineamento Colatina com os basaltos da Fm. Cabiúnas na Bacia de Campos, de idade Cretácea. Embora não existam trabalhos que detalhem especificamente o Lineamento Alegre, segmentos dessa feição foram representados em alguns mapas geológicos, como em Silva (1993) e Vieira (1997), que descrevem o segmento que atravessa o Complexo Intrusivo Santa Angélica (CISA) como fraturas. Já Vieira et al. (2014) reconhecem a presença de algumas partes do lineamento e interpretam um segmento NNW-SSE ao sul do CISA como uma falha transpressional de cinemática sinistral.

\subsubsection{Evolução tectonoestrutural da área offshore - Bacia de Campos}

A origem da Bacia de Campos é vinculada a mecanismos de distensão litosférica que conduziram à ruptura do paleocontinente Gondwana e à formação do Oceano Atlântico Sul (Milani et al., 2000). Sua evolução tectono-estratigráfica é semelhante à das bacias da margem continental do Sudeste Brasileiro, podendo ser dividida em quatro estágios principais: pré-rifte, rifte, transicional e drifte (e.g., Cainelli \& Mohriak, 1999; Ojeda, 1982).

A fase pré-rifte representa o estágio intracratônico do Supercontinente Pangea, precedendo a abertura do Oceano Atlântico Sul, marcado por elevadas taxas de soerguimento crustal e formação de grandes depressões periféricas (Cainelli \& Mohriak, 1999; Ojeda, 1982). Nessa fase ocorreram os primeiros derrames de lavas correspondentes aos basaltos toleíticos da Fm. Cabiúnas (Mohriak, 2012).

A fase rifte está associada à intensa atividade tectônica resultante de esforços distensivos no Cretáceo Inferior, que produziu um sistema de vales rifte alongados na direção NE-SW, 
subparalelos às principais estruturas do Embasamento pré-cambriano adjacente, desenvolvendo horstes, grábens e meios-grábens limitados principalmente por falhas sintéticas de mesma direção (Dias et al., 1987, 1990). Os falhamentos nas direções NNW-SSE e E-W possuem menor expressão, controlando, por vezes, depocentros localizados na bacia (Dias et al., 1990). A Falha de Campos ou linha charneira cretácea se destaca como uma importante estrutura dessa fase: constitui uma falha normal sintética (com mergulho na direção dos principais depocentros da bacia) que, orientada paralelamente à linha de costa, separa a área de ocorrência de sedimentos cretáceos da área do Embasamento raso (Fig. 2.1; Dias et al., 1990; Guardado et al., 1989). Fetter (2009) sugere que a estruturação do Embasamento Proterozóico, definida na bacia por altos de direções NE-SW e NNW-SSE, controla os depocentros principais da fase rifte. Cobbold et al. (2001) e Meisling et al. (2001) destacam o papel das zonas de transferência de direção NW-SE que segmentam obliquamente a margem passiva no Cretáceo Inferior. Essas estruturas controlam a variação da vergência no mergulho dos blocos da fase rifte e as mais importantes zonas de acumulação de sedimentos lacustres barremianos, as principais rochas geradoras de hidrocarbonetos na Bacia de Campos (Guardado et al., 2000). Falhas de transferência são estruturas de alto ângulo que transferem o deslocamento entre duas falhas normais, atuando como um sistema de balanceamento mecânico durante o rifteamento, uma vez que a distensão crustal ao longo de um rifte geralmente apresenta diferentes taxas de extensão crustal (Gibbs, 1984; Milani, 1990). Harding \& Lowell (1979) sugerem que essas falhas são parte integrante do sistema extensional.

Ainda na fase rifte, é importante citar a ocorrência do vulcanismo neocomiano, entre 122 Ma e 134 Ma (Mizusaki et al., 1989 apud Rangel et al., 1994), representado pelo clímax de extrusão de lavas basálticas da Fm. Cabiúnas (Winter et al., 2007). Sobre os basaltos da Fm. Cabiúnas, depositaram-se os sedimentos barremianos, compostos por conglomerados e arenitos proximais (Fm. Itabapoana), pelitos flúvio-lacustres (Fm. Atafona), folhelhos e coquinas (Fm. Coqueiros), correspondentes à parte inferior do Grupo Lagoa Feia (Winter et al., 2007; Rangel et al., 1994).

O estágio transicional representa o início da fase de subsidência termal, marcada pela suspensão do estiramento litosférico e do rifteamento da crosta continental (Cainelli \& Mohriak, 1999). Os sedimentos são compostos essencialmente por conglomerados e arenitos de borda de bacia (Fm. Itabapoana) e carbonatos, margas e arenitos de plataforma rasa (Fm. Gargaú e Fm. Macabu) recobertos por evaporitos (Fm. Retiro) da parte superior do Grupo Lagoa Feia (Winter et al., 2007). 
A fase drifte é marcada por pequenas discordâncias regionais e aumento da subsidência térmica offshore (Ojeda, 1982). Esse estágio é dividido em duas sequências: marinha transgressiva e marinha regressiva. A fase marinha transgressiva (Albiano-Cretáceo Superior) é caracterizada por carbonatos de água rasa do Grupo Macaé, com fácies arenosa (Fm. Goitacás) e calcarenítica (Fm. Quissamã), que gradam para uma sequência de margas e folhelhos (Fm. Outeiro; Dias et al., 1990; Mohriak, 2003; Winter et al., 2007). O Membro Tamoios (Fm. Ubatuba) corresponde a folhelhos bacinais que marcam o final da transgressão marinha (Rangel et al., 1994). Do Cretáceo Superior ao Neógeno, acontece a fase marinha regressiva, com a deposição de sedimentos siliciclásticos do Grupo Campos, composto por arenitos plataformais do Membro São Tomé, carbonatos plataformais do Membro Grussaí e calcirruditos e calcarenitos do Membro Siri, que compõem a Fm. Emborê (Mohriak, 2003; Winter et al., 2007). Pelitos bacinais da Fm. Ubatuba (Membro Geribá) e depósitos arenosos turbidíticos (Fm. Caraepebus) completam a sequência marinha do Grupo Campos (Winter et al., 2007).

O primeiro registro da tectônica de sal ocorre na transição Eo/Mesoalbiano, causada pela sobrecarga de sedimentos e basculamento da bacia, resultando na formação de almofadas de sal e falhas lístricas (Dias et al., 1990; Mohriak et al., 1990). No Neoalbiano ocorre nova fase de movimentação halocinética, que evoluiu formando falhas de crescimento (Dias et al., 1990). O intervalo entre o Cretáceo Superior e o Paleoceno corresponde ao período de margem passiva com processos de subsidência contínua e eventuais movimentos residuais de sal (Dias et al., 1990; Mohriak et al., 1990; Cainelli \& Mohriak, 1999). Boa parte das falhas normais da Bacia de Campos relacionadas à tectônica de sal apresenta geometria sintética (Mohriak, 2003). Guardado et al., (1989) pontuam que essas falhas foram reativadas do Albiano ao Holoceno, desempenhando importante papel no controle da sedimentação e formação de armadilhas nas principais acumulações de hidrocarbonetos da Bacia de Campos.

\subsection{Material e Métodos}

A área de estudo é delimitada por um polígono traçado no entorno do Lineamento Alegre que abrange, em sua porção continental, uma pequena área no extremo sudeste do Estado de Minas Gerais, todo o sul do Estado do Espírito Santo e parte da região norte do Estado do Rio de Janeiro, prolongando-se para a área oceânica até a porção central da Bacia de Campos (Fig. 2.2). A análise estrutural consistiu em observações realizadas em superfície, por meio da análise dos dados de sensoriamento remoto e aquisição de dados estruturais em campo e, em 
subsuperfície, por meio da análise de perfis sísmicos de reflexão e correlação com perfis geofísicos de poços.

A análise por sensoriamento remoto consistiu na integração do Modelo Digital de Elevação (MDE) e fotografias aéreas em ambiente SIG (Sistema de Informações Geográficas), com o auxílio do software ArcGis 10.2, e identificação das principais feições estruturais próximas ao Lineamento Alegre, segundo os critérios definidos por O'Leary et al. (1976). O levantamento de campo englobou a análise geométrica e cinemática das feições estruturais planares e lineares, como juntas, falhas, estrias e foliações, buscando a correlação estrutural das estruturas de campo com as observadas em sensoriamento remoto, assim como as relações de corte entre as estruturas. O banco de dados estruturais de campo contempla 385 afloramentos, agrupados em dois conjuntos. O primeiro conjunto inclui todos os afloramentos que se encontram em uma distância de 0 a $40 \mathrm{~km}$ do traçado do lineamento (buffer $40 \mathrm{~km}$ ), enquanto o segundo conjunto inclui os afloramentos que ocorrem a uma distância de 0 a $3 \mathrm{~km}$ (buffer 3 km; Fig. 2.2). Essa divisão possui a finalidade de evidenciar o controle das estruturas atuantes na região de influência do Lineamento Alegre em relação à estruturação regional. Foram gerados estereogramas em projeção de hemisfério inferior em rede de igual área utilizando-se o software Open Stereo (Grohmann et al., 2011). A análise do stress tectônico relacionado à evolução do Lineamento Alegre foi realizada pela inversão de dados cinemáticos de falhas e juntas pelo método dos diedros retos (Angelier \& Mechler, 1977) no software WinTensor v. 5.05 (Delvaux \& Sperner, 2003). 




Fig. 2. 2: Localização dos afloramentos estudados na área continental e, na Bacia de Campos, a localização da área de interpolação com as seções sísmicas e os poços utilizados. ES = Espírito Santo, RJ = Rio de Janeiro, MG = Minas Gerais.

A análise de subsuperfície foi realizada pela interpretação estrutural de 31 linhas sísmicas 2D (3.051,544 Km) e 13 poços de exploração e produção de petróleo, cujos dados foram fornecidos pela Agência Nacional do Petróleo (ANP; Fig. 2.2). As informações lito e cronoestratigráficas obtidas a partir dos poços, tais como discordâncias e limites entre formações (marcadores estratigráficos; Fig. 2.3), juntamente com os perfis geofísicos dos poços (raios gama, sônico e densidade), foram utilizados para definição das idades dos refletores sísmicos e a correlação lateral entre as linhas. Os poços (em profundidade) foram amarrados com as linhas sísmicas (em tempo) utilizando-se a velocidade intervalar registrada nos perfis sônicos em microssegundo por pé ( $m s / f e e t)$ para cada poço. Dessa forma, o topo do Embasamento foi calibrado com o topo dos basaltos (TB) da Fm. Cabiúnas; o topo da Sequência Rifte, com a Fm. Coqueiros; o topo da Sequência Pós-Rifte, com a discordância pré-evaporítica (DPE); o topo do Sal, com a Fm. Retiro; o topo do Albiano, com a Fm. Outeiro; o topo da Sequência Cenomaniano-Maastrichtiano, com o Membro Tamoios (Fm. Ubatuba); o topo da 
Sequência Paleoceno-Oligoceno, com o Membro Siri (Fm. Emborê) e o topo da Sequência Mioceno- Pleistoceno, com o Fundo do Mar (Fig. 2.3).

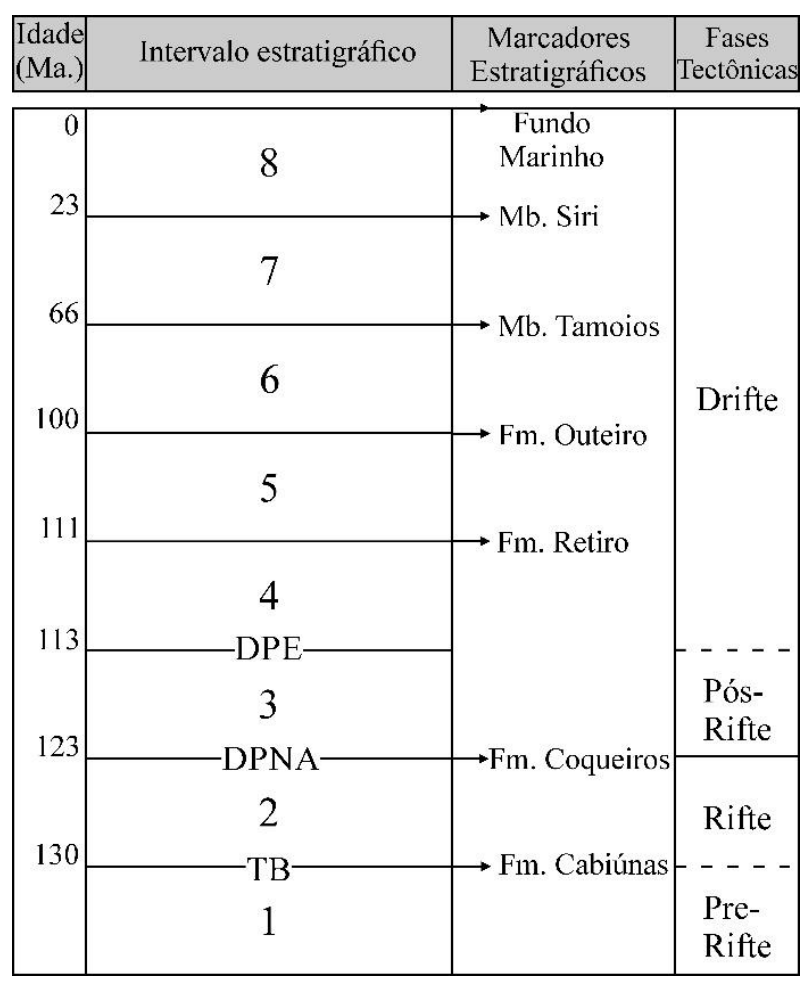

Fig. 2. 3: Ilustração dos marcadores estratigráficos identificados nos poços utilizados para definir a idades dos horizontes sísmicos (simplificado de Winter et al., 2007). Intervalos estratigráficos: $1=$ Embasamento, $2=$ Sequência Rifte, 3 = Sequência Pós-Rifte, 4 = Sal, 5 = Albiano, $6=$ Cenomaniano-Maastrichtiano, $7=$ PaleocenoOligoceno, 8 = Mioceno-Pleistoceno, TB = Topo dos basaltos, DNPA = Discordância Pré-Neo-Alagoas, DPE = Discordância Pré-Evaporítica.

Os horizontes sísmicos foram interpretados em todas as 31 linhas sísmicas 2D em tempo duplo (TWT), obtendo-se uma malha de pontos para cada horizonte interpretado. Foram geradas superfícies 3D para cada horizonte a partir da interpolação dos dados pontuais delimitados por um polígono (Fig. 2.2) pelo método de interpolação de mínima curvatura. A delimitação do polígono baseou-se na delimitação da área onde houve o maior adensamento de linhas sísmicas. Foram obtidas, então, superfícies em tempo duplo para o topo: (i) do Embasamento; (ii) da Sequência Rifte; (iii) da Sequência Pós-Rifte; (iv) do Sal; (v) da Sequência Albiana; (vi) da Sequência Cenomaniana-Maastrichtiana; (vii) da Sequência do Paleoceno-Oligoceno e (viii) da Sequência do Mioceno-Pleistoceno. A interpolação dos horizontes estratigráficos interpretados nas seções sísmicas gerou superfícies tridimensionais que, quando projetadas em mapa, permitiram evidenciar a estruturação dos pacotes.

\subsection{Resultados e Discussão}


Os dados obtidos por meio da análise estrutural em superfície e em subsuperfície são apresentados abaixo, assim como é discutida a implicação das informações para a evolução estrutural da região.

\subsubsection{Análise estrutural em superfície}

A análise de superfície por sensoriamento remoto permitiu identificar o traçado do Lineamento Alegre, bem marcado no relevo, definido por vales encaixados com direção predominante N25W, subparalelo ao Lineamento Colatina (Fig. 2.1). O Lineamento Alegre é identificado desde a região leste de Minas Gerais até o extremo sul do Espírito Santo, onde perde definição. Nessa região, assume-se que seu traçado sofre um deslocamento (Fig. 2.4a), sendo inferido pelo controle que exerce na deposição de coberturas cenozoicas. A linha de costa no extremo nordeste do Estado do Rio de Janeiro é paralela a essa direção e, a partir daí, o traço foi inferido até a porção central da Bacia de Campos (Fig. 2.1). No assoalho oceânico, o traço NNW-SSE não é marcado no local da projeção do lineamento, mas é notável seu paralelismo com uma inflexão para NNW-SSE do talude oceânico ao Nordeste, junto à projeção do Lineamento Colatina para a área oceânica (Figs. 2.1 e 2.2).

A análise de lineamentos revelou, na área continental, o predomínio dos trends estruturais nas direções NNE-SSW a NE-SW e, subordinadamente, WNW-ESE a NW-SE (Fig. 2.4a). De forma menos marcante, pode-se individualizar um conjunto de lineamentos NNWSSE, paralelos ao Lineamento Alegre, e o seu traço principal, que atravessa toda a área de forma individualizada e relativamente contínua (Figs. 2.4a e 2.4c).

$\mathrm{Na}$ porção setentrional da área continental, o Lineamento Alegre corta a Zona de Cisalhamento Guaçuí e o Complexo Intrusivo Santa Angélica (CISA; ca. 520-480 Ma; Söllner et al., 2000), definindo neste último dois núcleos gabroicos, um ao Nordeste e outro ao Sudoeste do Lineamento (Fig. 2.4b). O traçado do Lineamento Alegre coincide com o contato entre unidades do Embasamento Neoproterozóico e dos Granitóides Neoproterozóicos, conforme o mapa geológico de Vieira (1997; Fig. 2.4b). Na sua porção central, o Lineamento ocorre como um feixe de lineamentos responsável pelo controle das formas de relevo e de depósitos colúvioaluvionares (Fig. 2.4b). 

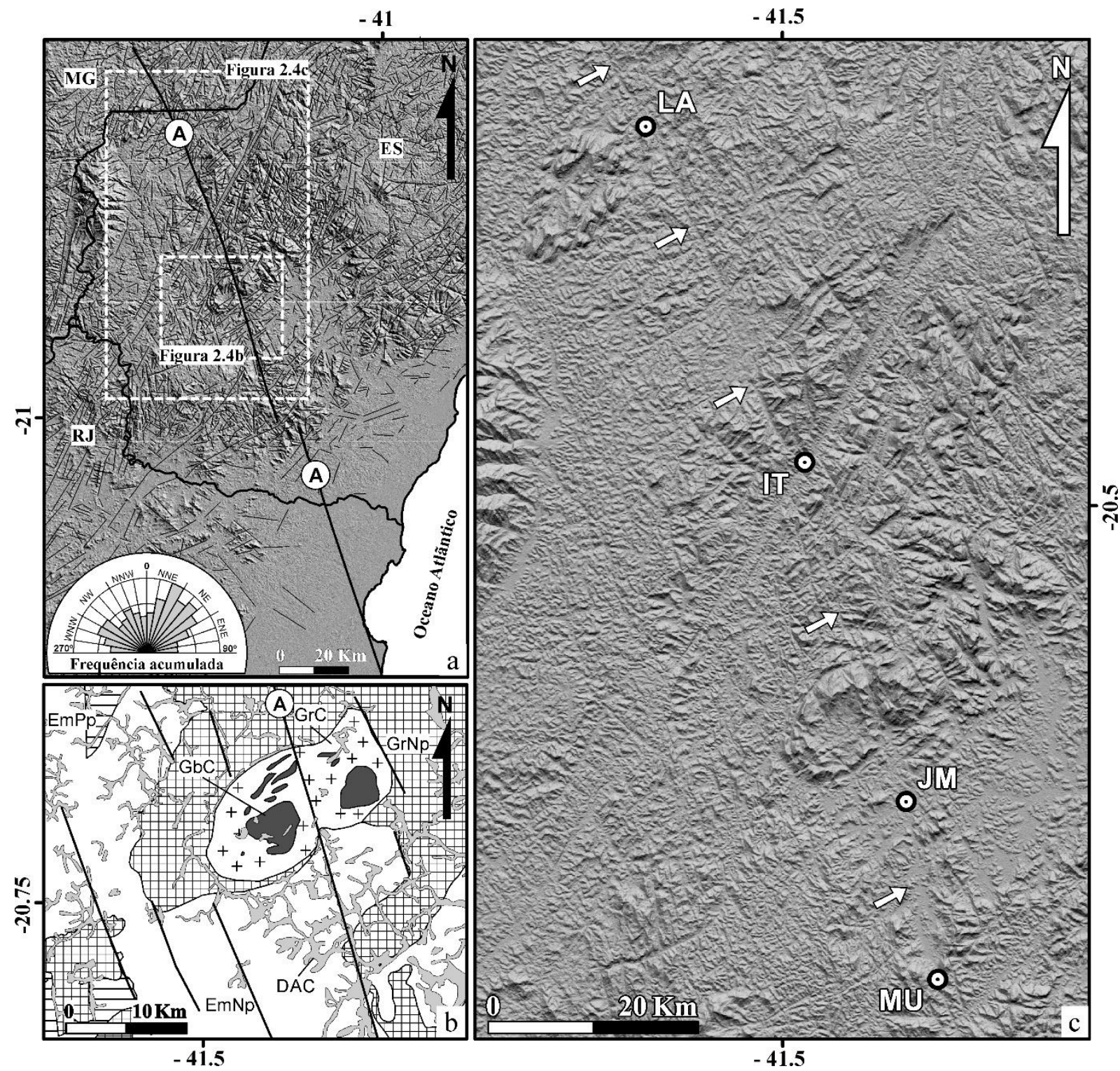

Fig. 2. 4: Contexto regional da área de influência do Lineamento Alegre na porção continental da área de estudo. (a) Mapa de lineamentos em imagem de relevo sombreado (iluminação de NE), mostrando o traçado do Lineamento Alegre e o diagrama de rosetas, (b) Mapa geológico da região do Maciço Santa Angélica (modificado de Vieira, 1997 e Wiedemann-Leonardos et al., 2000); e (c) Imagem de relevo sombreado (iluminação de NE e NW sobrepostas), mostrando a localização dos diques máficos (círculos em preto) no traçado do Lineamento Alegre (indicado pelas setas brancas). Litologias: $\mathrm{EmPp}=$ Embasamento Paleoproterozóico, $\mathrm{EmNp}=$ Embasamento Neoproterozóico, $\mathrm{GrNp}=$ Granitóides Neoproterozóicos, $\mathrm{GrC}=$ Granitóides pós-colisionais Cambrianos, $\mathrm{GbC}=$ Gabros Cambrianos, $\mathrm{DAC}=$ Depósitos aluvio-coluvionares Cenozoicos. Diques: LA = Lajinha, IT = Itaici, JM = Jerônimo Monteiro, MU = Muqui.

Em campo foram identificados, ao longo do Lineamento Alegre, quatro diques de composição gabroica, compostos basicamente por plagioclásio e augita, com afinidade alcalina e toleítica (Mendes et al., 2014; Fig. 2.4c). O significado da ocorrência de diques similares na região Norte do Estado do Espírito Santo, ao longo do Lineamento Colatina, tem sido alvo de discussões por parte de alguns pesquisadores. A um desses corpos foi atribuída idade jurássica (Silva et al., 1987), e sua formação foi associada ao derrame basáltico da Fm. Cabiúnas na Bacia 
de Campos (Valente et al., 2009 e Novais et al., 2004). Porém, análises isotópicas de U-Pb realizadas em diques básicos subparalelos ao Lineamento Colatina atribuíram idade cambriana para essas intrusões (Belém et al., 2014). Os diques do sul do Espírito Santo estão em fase de datação pela equipe de um dos autores deste trabalho. Até o momento, o que se pode afirmar é que a presença desses diques junto ao traço do Lineamento Alegre indica tratar-se de uma faixa que foi submetida a esforços distensivos atuantes em mais de um pulso tectônico.

As estruturas planares identificadas em campo foram agrupadas em foliações dúcteis (bandamento e foliação milonítica) e rúpteis (juntas e falhas) e as estruturas lineares são estrias de falha (Fig. 2.5).

As foliações têm direção principal NE-SW, mergulhando para SE (Fig. 2.5a). O bandamento possui médio ângulo de mergulho, enquanto a foliação milonítica ocorre predominantemente com alto ângulo e compõem as zonas de cisalhamento como a Guaçuí e Batatal. Quando analisadas no buffer de $3 \mathrm{~km}$, as foliações mostram o mesmo padrão, com estruturas predominantemente de direção NE-SW mergulhando para SE com médio a alto ângulo (Fig. 2.5b). Considera-se, portanto, que o Lineamento Alegre compõe uma estrutura geológica que corta as estruturas dúcteis, sendo, assim, mais jovem que a estruturação formada no ciclo orogênico Brasiliano/Pan-Africano ou, pelo menos, originada em fase tardia.

As famílias de juntas de direções WNW-ESE e NW-SE são as mais frequentes na área de estudo (buffer de $40 \mathrm{~km}$ ) e, subordinadamente, ocorrem outras com direção NE-SW e NNESSW (Fig. 2.5c). No conjunto de medidas realizadas no buffer de $3 \mathrm{~km}$, as juntas do quadrante NE-SW perdem representatividade e permanece a família NW-SE de alto ângulo, destacandose também um grupo de direção WNW-ESE com médio ângulo de mergulho para NNE (Fig. $2.5 d)$. 


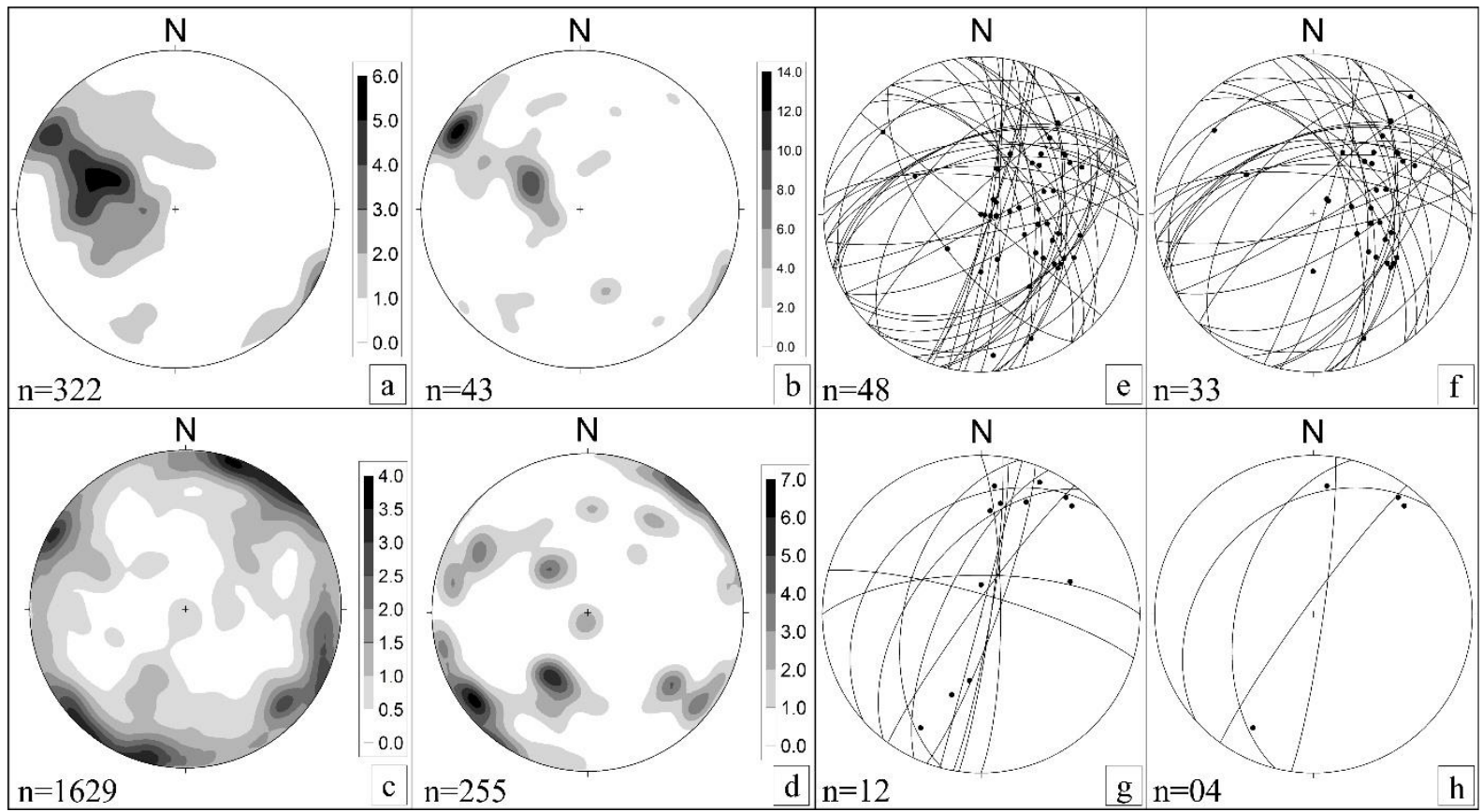

Fig. 2. 5: Projeções estereográficas (projeção de hemisfério inferior em rede de igual área) das estruturas planares (foliações, juntas e falhas) adquiridas em campo mostradas em buffers de 40 e $3 \mathrm{Km}$ do Lineamento Alegre. (a) Foliações das rochas ígneas e metamórficas (buffer de $40 \mathrm{Km}$ ), (b) foliações das rochas ígneas e metamórficas (buffer de $3 \mathrm{Km}$ ), (c) juntas (buffer de $40 \mathrm{Km}$ ), (d) juntas (buffer de $3 \mathrm{Km}$ ), (e) falhas normais (buffer de $40 \mathrm{Km}$ ), (f) falhas normais (buffer de $3 \mathrm{Km}$ ), (g) falhas transcorrentes destrais (buffer de $40 \mathrm{Km}$ ), (h) falhas transcorrentes destrais (buffer de $3 \mathrm{Km}) . \mathrm{n}=$ número de medidas.

A ausência de marcador temporal para essas descontinuidades dificulta a interpretação quanto à sua gênese, mas algumas possibilidades podem ser aventadas. As juntas do quadrante NE-SW são compatíveis com juntas de partição que poderiam ter se formado no evento distensivo de direção geral NW-SE atuante na região Sudeste do Brasil desde a fase rifte (Chang et al., 1992; Stanton et al., 2010) até o Paleógeno (Riccomini et al., 1989) e que também foi identificado neste estudo, conforme descrito adiante. A família de juntas NW-SE, bem marcada na área de estudos, pode ter se originado pela atuação de um binário transcorrente destral referido por muitos autores como o evento neotectônico mais importante da região Sudeste do Brasil (e.g., Hasui, 1990). Já a família de juntas mais frequente, de direção WNW-ESE, poderia ser oriunda do evento compressivo E-W, que alguns autores colocam como ativo no Holoceno (Salvador \& Riccomini, 1995; Mello, 1997) e que poderia formar juntas de tensão.

Outra possibilidade a ser aventada é que essas juntas do quadrante NW-SE sejam a continuidade ou terminação das zonas de transferência que se projetariam das bacias costeiras rumo à área continental. De acordo com Stanton et al. (2010), durante a fase rifte da Bacia de Campos, estruturas rúpteis formadas na direção WNW-ESE seriam rotacionadas até adquirirem a orientação NW-SE. Assim, o conjunto NW-SE poderia representar juntas relacionadas às falhas de transferência adentrando ao continente, formadas inicialmente na direção WNW-ESE 
e posteriormente rotacionadas para NW-SE. Ainda, Cobbold et al. (2001) coloca a última reativação das zonas de transferência em um regime transpressional (transcorrência destral) no início do Neógeno, que seria compatível com a formação dessas descontinuidades que marcam de forma profusa a área continental estudada.

As falhas medidas em campo muitas vezes afetam rochas alteradas do Embasamento cristalino e algumas delas possuem estrias impressas sobre material de preenchimento composto por óxi-hidróxidos de Fe e Mn e argilo-minerais (Fig. 2.6).

As falhas normais medidas no buffer de $40 \mathrm{Km}$ mostram dois conjuntos principais, um de direção NNE-SSW com alto ângulo de mergulho para ESE e outro de direção NE-SW com médio ângulo de mergulho para SE. Também ocorrem falhas de direção ENE-WSW com médio ângulo de mergulho tanto para NNW quanto para SSE, e falhas NW-SE com médio ângulo de mergulho para NE (Fig. 2.5e). Na região mais próxima do lineamento (buffer de $3 \mathrm{~km}$ ), destacam-se dois conjuntos de falhas: um com direção ENE-WSW mergulhando predominantemente para NNW a médio ângulo, e outro de direção entre NNW-SSE e NNESSW mergulhando predominantemente para E com médio ângulo (Fig. 2.5f). É importante destacar que as falhas normais são relativamente mais abundantes na proximidade do lineamento do que no restante da área, e que muitas delas são paralelas ou subparalelas à direção do Lineamento Alegre. As falhas transcorrentes possuem cinemática destral e não revelam grande variação de atitude quando observadas nos buffers de $40 \mathrm{~km}$ e de $3 \mathrm{~km}$ (Fig. $2.5 \mathrm{~g}$ e $5 \mathrm{~h}$ ). A principal família encontrada possuiu direção NNE-SSW com alto ângulo de mergulho para ESE e, subordinadamente, médio ângulo para WNW.

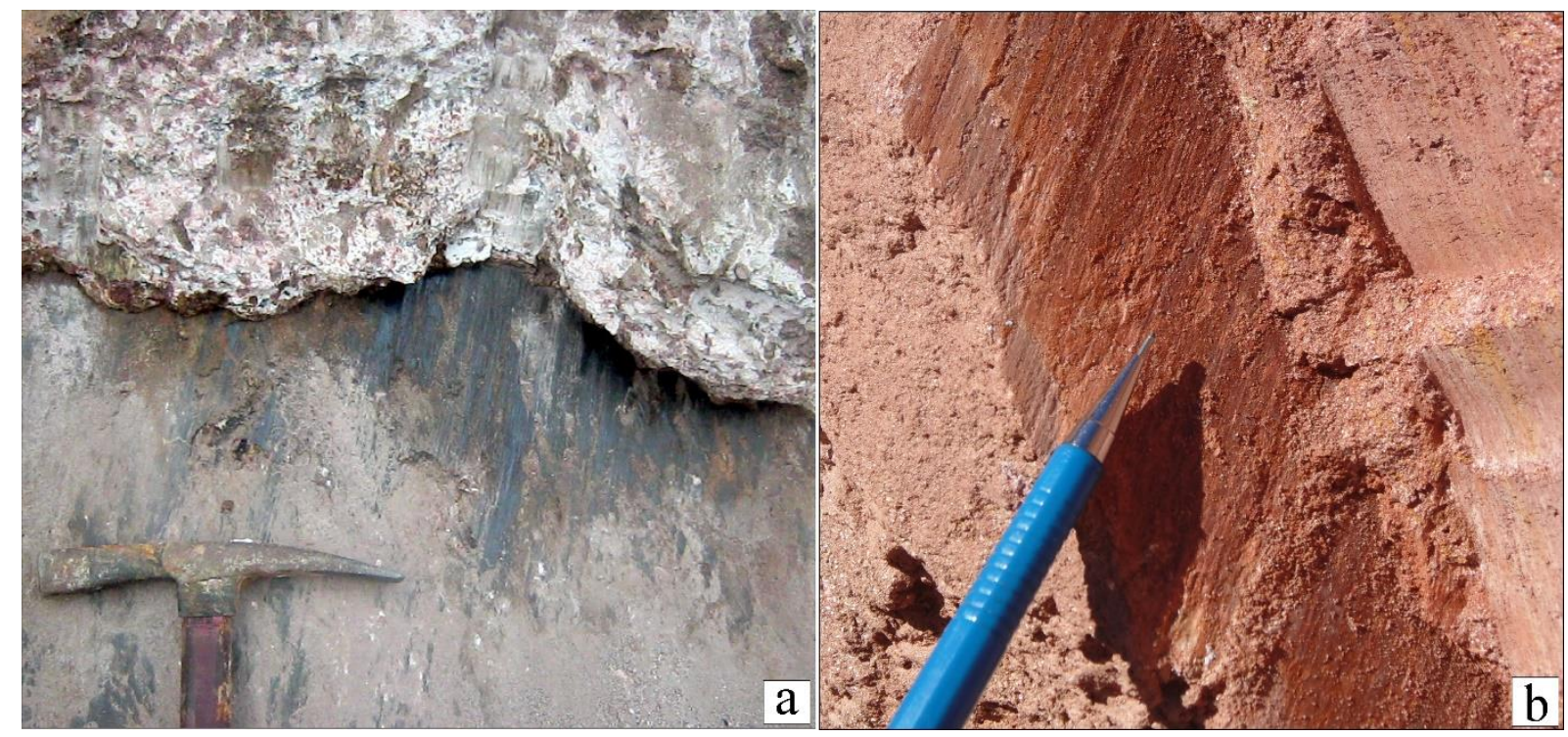

Fig. 2. 6: Estrias de falhas marcadas em planos de falhas preenchidos por (a) óxido de Mn (N05W/45NE) e (b) argilo-minerais e/ou óxi-hidróxidos de Fe (N80E/55NW). 
A separação das falhas em subconjuntos para a análise cinemática foi realizada de maneira automática com a utilização do software WinTensor. A separação baseou-se na maior compatibilidade entre as medidas, que resultou em dois conjuntos de falhas: um conjunto de 50 falhas compatíveis (aproximadamente 74\%) e um conjunto de 18 falhas incompatíveis (aproximadamente 26\%). A inversão dos dados de cinemática de falhas do conjunto compatível indicou um campo de tensão distensivo com eixo de tensão mínima posicionado na direção NW-SE (Fig. 2.7). Com relação ao conjunto de medidas incompatíveis com esse tensor, não é possível até o momento atribuí-lo a outro evento tectônico, já que não foram observadas relações de corte entre as estruturas e não há marcadores estratigráficos para datação relativa. Também é possível que essas falhas consideradas incompatíveis tenham sido formadas sob o mesmo regime de tensões, por movimentações locais relacionadas a rearranjos de blocos tectônicos.

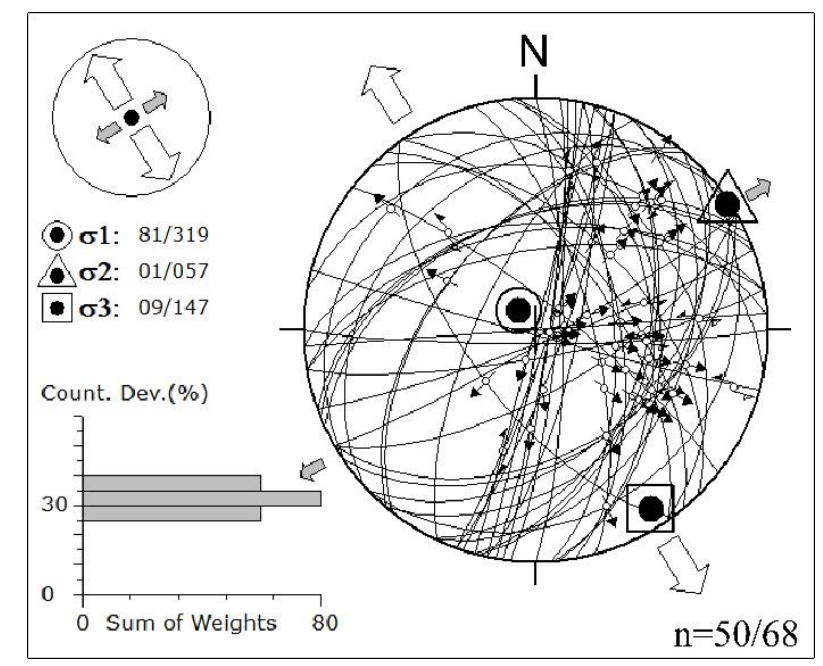

Fig. 2. 7: Campo de paleotensores obtido a partir da inversão dos dados de falhas no WinTensor por meio do método dos diedros retos mostrando distensão no quadrante NW-SE. $\mathrm{n}=$ número de dados representados/dados totais, $\sigma 1=$ eixo de tensão máxima, $\sigma 2=$ eixo de tensão intermediária, $\sigma 3=$ eixo de tensão mínima.

Essa distensão NW-SE, vinculada aos principais falhamentos normais e oblíquos nas direções NE-SW e NNE-SSW, pode ser correlacionada àquela atuante durante a fase rifte, já descrita por Chang et al. (1992) e Stanton et al. (2010), dentre outros. Aqui, mais uma vez, a ausência de marcador temporal permite também colocar esse evento como atuante entre o Paleoceno e o final do Oligoceno, conforme observado por Riccomini et al. (1989) no RCSB, dentre outros autores (Salvador \& Riccomini, 1995; Ferrari, 2001). É importante observar que a atitude predominante das falhas normais geradas por essa distensão é concordante com a da foliação regional e das zonas de cisalhamento, atestando o controle da deformação pelas 
anisotropias pré-cambrianas. De fato, nos trabalhos de campo foram observadas muitas estrias de falha marcadas sobre planos da foliação. As falhas normais na direção do Lineamento Alegre, variando de NNW-SSE a NW-SE, também podem ser relacionadas a esse evento distensivo, que teria atuado de forma a reativar fraturas de mesma direção existentes desde o Cambriano. A existência de descontinuidades de direção NNW-SSE (lineamento) poderia servir, agora, como zonas de alívio de tensão para o esforço distensivo, reativando os planos de fratura como falhas normais.

\subsubsection{Análise estrutural em subsuperfície}

Foram identificadas 798 falhas nas 31 seções sísmicas 2D (strike e dip) analisadas. Para cada falha identificada, foi possível determinar a direção aparente do mergulho e o mergulho aparente, além do horizonte afetado. Verificou-se a presença de dois estilos estruturais dominantes: (i) falhas normais que afetam o Embasamento e a Sequência Rifte (thick-skinned deformation); e (ii) estruturas extensionais geradas principalmente por sobrecarga e tectônica do sal que afetam as sequências superiores (thin-skinned deformation).

Na figura 2.8, é mostrada a interpretação de três seções sísmicas perpendiculares ao Lineamento Alegre (strike sections; direção aproximada NE-SW), posicionadas desde a porção mais próxima à linha de costa até a porção mais distal, próxima ao talude oceânico. Na Fig. 2.8a aparecem falhas que delimitam um alto estrutural correspondente ao Alto de Badejo, identificado antes por Guardado et al. (2000). Dados aeromagnéticos de Stanton et al. (2010) e Lourenço et al. (2014) mostram o alinhamento de uma anomalia magnética negativa de trend NNW-SSE separando o Alto de Badejo do Alto Magnético de Campos. Na Fig. 2.8b, observamse falhas com rejeito normal aparente e alto ângulo de mergulho no trecho do prolongamento do Lineamento Alegre para a área offshore. Essas falhas compõem um feixe ao longo de um trecho de $40 \mathrm{~km}$, controlando um baixo estrutural na porção NE da bacia, que corresponde ao Baixo Corvina-Parati (Guardado et al., 2000; Fig. 2.8c). É importante destacar que, em determinados locais da área continental, o Lineamento Alegre também se manifesta sob a forma de um feixe de lineamentos (Fig. 2.4b).

A ocorrência de falhas que parecem ser vinculadas ao Lineamento Alegre se restringe às porções proximal e central da bacia. Nas seções distais, como a ilustrada na Fig. 2.8c, não é possível fazer tal correlação. Por outro lado, nessa seção distal, um baixo estrutural aparece no lado NE, indicando a atuação de estruturas de direção NW-SE que pode ser interpretada como uma falha de transferência. A identificação de falhas de transferência em seções sísmicas é 
baseada em elementos que indicam transcorrência, principalmente pela presença de estruturas em flor (Zalán, 1986). Buscaram-se indicativos de movimentação transcorrente na interpretação das seções sísmicas, mas, dentre as 31 seções disponíveis, apenas 3 apresentaram indícios de movimentação transcorrente. Na figura 2.8b é possível observar uma estrutura em flor negativa associada a falhas no Embasamento, que ocorre na mesma posição das falhas de transferência citadas na literatura (Cobbold et al., 2001; Meisling et al., 2001; Lourenço et al., 2014).



Fig. 2. 8: Seções sísmicas strike selecionadas dentre as 31 seções interpretadas no presente trabalho. Em (a) é mostrada a interpretação da linha 0231-1233_A; em (b), a interpretação da linha SPP992323; e em (c), a interpretação da linha 0221-6960. 1 = Embasamento, 2 = Sequência Rifte, 3 = Sequência Pós-Rifte, $4=$ Sal, $5=$ Albiano, 6 = Cenomaniano-Maastrichtiano, 7 = Paleoceno-Oligoceno, 8 = Mioceno-Pleistoceno.

No Embasamento e na Sequência Rifte, tanto as falhas sintéticas quanto as antitéticas possuem rejeito normal aparente, com médio a alto ângulo de mergulho. Essas estruturas definem blocos sob a forma de altos e baixos estruturais. Entre as 218 falhas que deformam o 
Embasamento e a Sequência Rifte, 20\% deformam também pacotes mais jovens (Fig. 2.9a). Em 14 das 31 seções interpretadas, foram identificadas falhas que afetam a Sequência Rifte com rejeito normal aparente de cerca de $40 \mathrm{~ms}$ até $300 \mathrm{~ms}$ (milissegundos; tempo duplo) e que também afetam a Sequência Pós-Rifte, mas com rejeito de $10 \mathrm{~ms}$ até $200 \mathrm{~ms}$ (Fig. 2.9b). As falhas que afetam os pacotes mais jovens e as falhas que afetam as Sequências Rifte e Pós Rifte com rejeito diferencial indicam reativações de estruturas formadas na fase rifte. A maior população de falhas que afetam o Embasamento e a Sequência Rifte, associadas à deformação thick-skinned, são observadas em seções strike com mergulho aparente de médio a alto ângulo para NE, e em seções dip com mergulho aparente de médio a alto ângulo para SE.

As falhas associadas ao sistema halocinético foram identificadas em 13 das 31 seções sísmicas interpretadas. Elas iniciam na base do sal e terminam no pacote do MiocenoPleistoceno, sendo predominantemente sintéticas (Fig. 2.9c). Essas falhas relacionadas à deformação thin-skinned são observadas em sua maioria nas seções strike com mergulho aparente de médio ângulo para NE. Em seções dip, elas ocorrem com mergulho aparente para SE. Embora o strike dessas falhas possua a mesma direção das falhas da fase rifte, os processos formadores delas estão relacionados ao basculamento da bacia para leste e à compactação diferencial de sedimentos após o período de quiescência tectônica (Guardado et al., 1989). Contudo, movimentações relacionadas à reativação de estruturas da fase rifte podem ocorrer associadas às falhas halocinéticas.

Foram observadas também falhas que afetam apenas as sequências superiores, com rejeito de até $120 \mathrm{~ms}$ (Fig. 2.9a). Essas falhas podem ser correlacionadas às falhas gravitacionais (Vincentelli, 2013) formadas em resposta ao peso da cobertura sedimentar sobre níveis basais móveis, como forma de compensação do pacote sedimentar. 

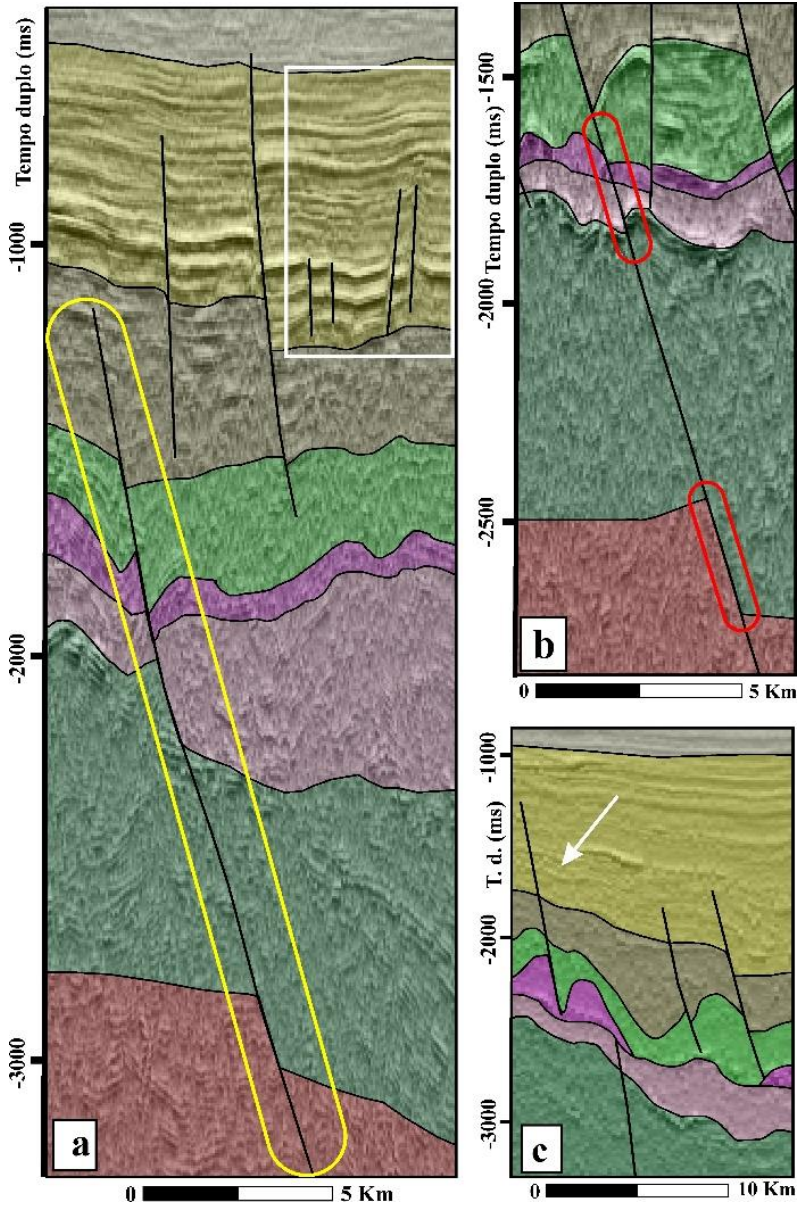

Fig. 2. 9: Detalhes da interpretação estratigráfica e estrutural das linhas sísmicas mostradas na figuras $2.8 \mathrm{a}$ e $2.8 \mathrm{~b}$. Em (a) é possível observar uma falha normal com mergulho aparente no sentido NE afetando o Embasamento até a Sequência do Cenomaniano-Maastrichtiano, com rejeito diferencial (polígono amarelo), além de falhas normais com mergulho aparente para NE afetando somente a Sequência do Paleoceno-Oligoceno (polígono branco). Em (b), uma falha normal com mergulho aparente no sentido NE afeta o Embasamento com rejeito de $260 \mathrm{~ms}$ e as Sequências Rifte, Pós-Rifte e Sal com rejeito de até 30 ms (polígonos em vermelho). Em (c) ocorre uma falha normal com mergulho aparente no sentido NE afetando a Sequência do Sal (seta branca).

A variação de espessura dos pacotes sedimentares indica a presença de depocentros possivelmente controlados por estruturas correlatas ao Lineamento Alegre, delineando altos e baixos estruturais formados na fase rifte. Na região localizada a NE do Lineamento, o Baixo Corvina-Parati, evidenciado desde a Sequência rifte até o Paleoceno-Oligoceno, propiciou um maior espaço para a acumulação de sedimentos nessa área. A Sequência do PaleocenoOligoceno se destaca nesse contexto, apresentando maior acúmulo de sedimentos nessa região. Esse aumento de espessura pode ser explicado pelo evento distensivo NW-SE/WNW-ESE, associado ao soerguimento da Serra do Mar (Riccomini et al., 1989), que culminou em intensa erosão na área continental e significativo aumento do aporte de sedimentos para a bacia (Figueiredo et al., 1983 apud Dias et al., 1990). Dados termocronológicos da região SE e NE do Brasil indicam uma maior taxa de denudação no intervalo entre 40 Ma e 0 Ma (Jelinek et al., 2014). Na Sequência Mioceno-Pleistoceno, a depressão é completamente preenchida, dando 
forma ao fundo marinho. Nessa sequência, é possível observar que a atuação do Baixo CorvinaParati na acumulação de sedimentos é quase nula. A movimentação tectônica dessa fase é marcada pela presença das falhas gravitacionais e movimentos residuais halocinéticos na porção central da bacia.

Nas superfícies tridimensionais geradas por interpolação dos horizontes interpretados (Fig. 2.10), a estruturação NE-SW se manifesta em todas as sequências, com controle mais pronunciado na região do talude oceânico. Nos mapas do topo do Embasamento até o topo do Cenomaniano-Maastrichtiano (Figs. 2.10a a 2.10f), observam-se altos estruturais na porção WNW da área de interpolação e baixos no lado ENE. As porções altas e baixas são delineadas por isolinhas alinhadas na direção NNW-SE, paralela à projeção do Lineamento Alegre para a bacia (linha pontilhada). É visível também a presença de inflexões na direção NW-SE, sugerindo a ação de estruturas de mesma direção na geometria dos pacotes.

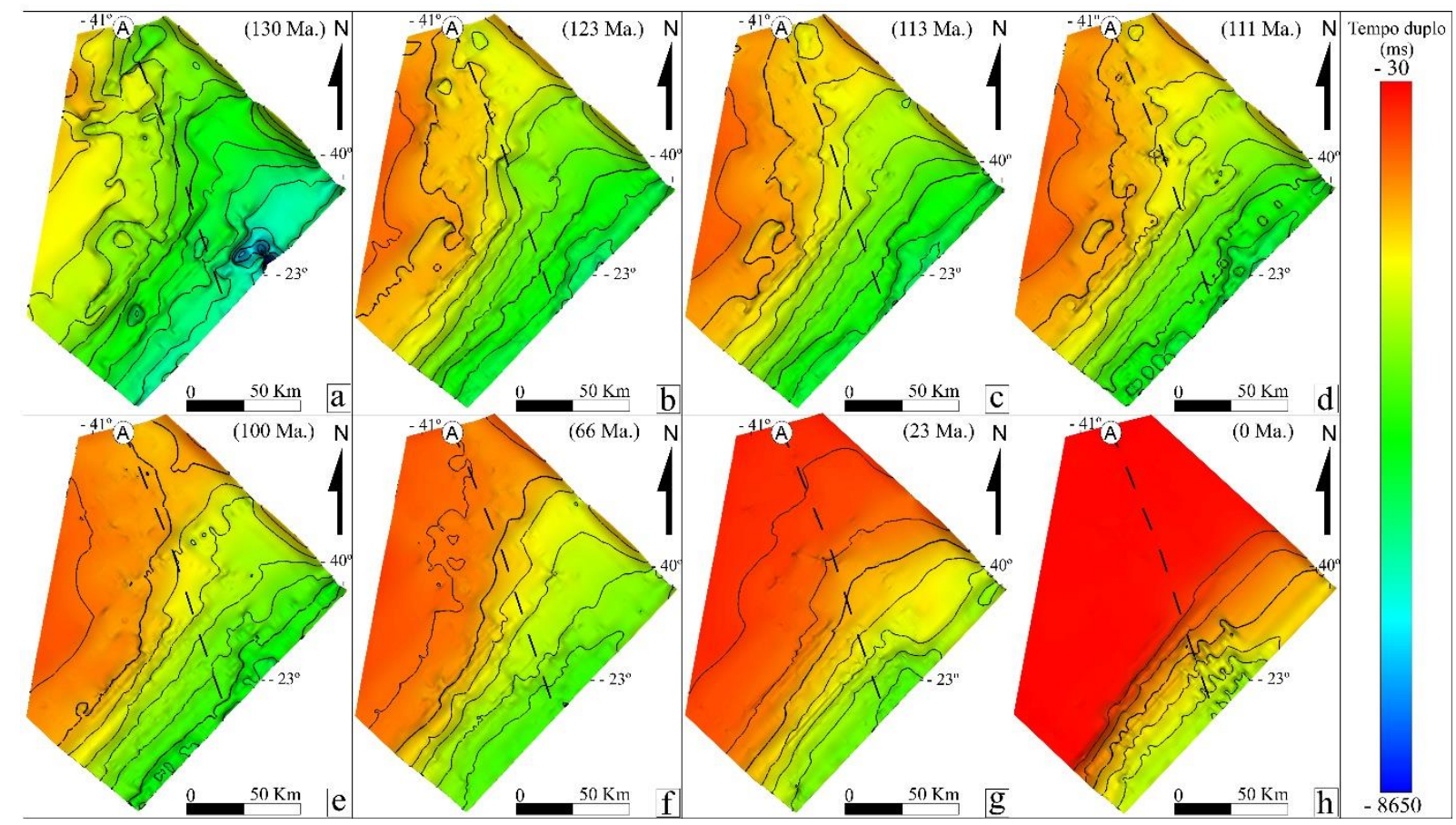

Fig. 2. 10: Mapas estruturais em tempo duplo para o topo: (a) do Embasamento; (b) da Sequência Rifte; (c) da Sequência Pós-Rifte; (d) do Sal; (e) da Sequência do Albiano; (f) da Sequência do Cenomaniano-Maastrichtiano; (g) da Sequência do Paleoceno-Oligoceno e (h) da Sequência do Mioceno-Pleistoceno.

A integração entre a interpretação sísmica e os mapas estruturais gerou um quadro esquemático interpretativo dos principais elementos estruturais da região central da Bacia de Campos, que é ilustrado na Figura 2.11. 


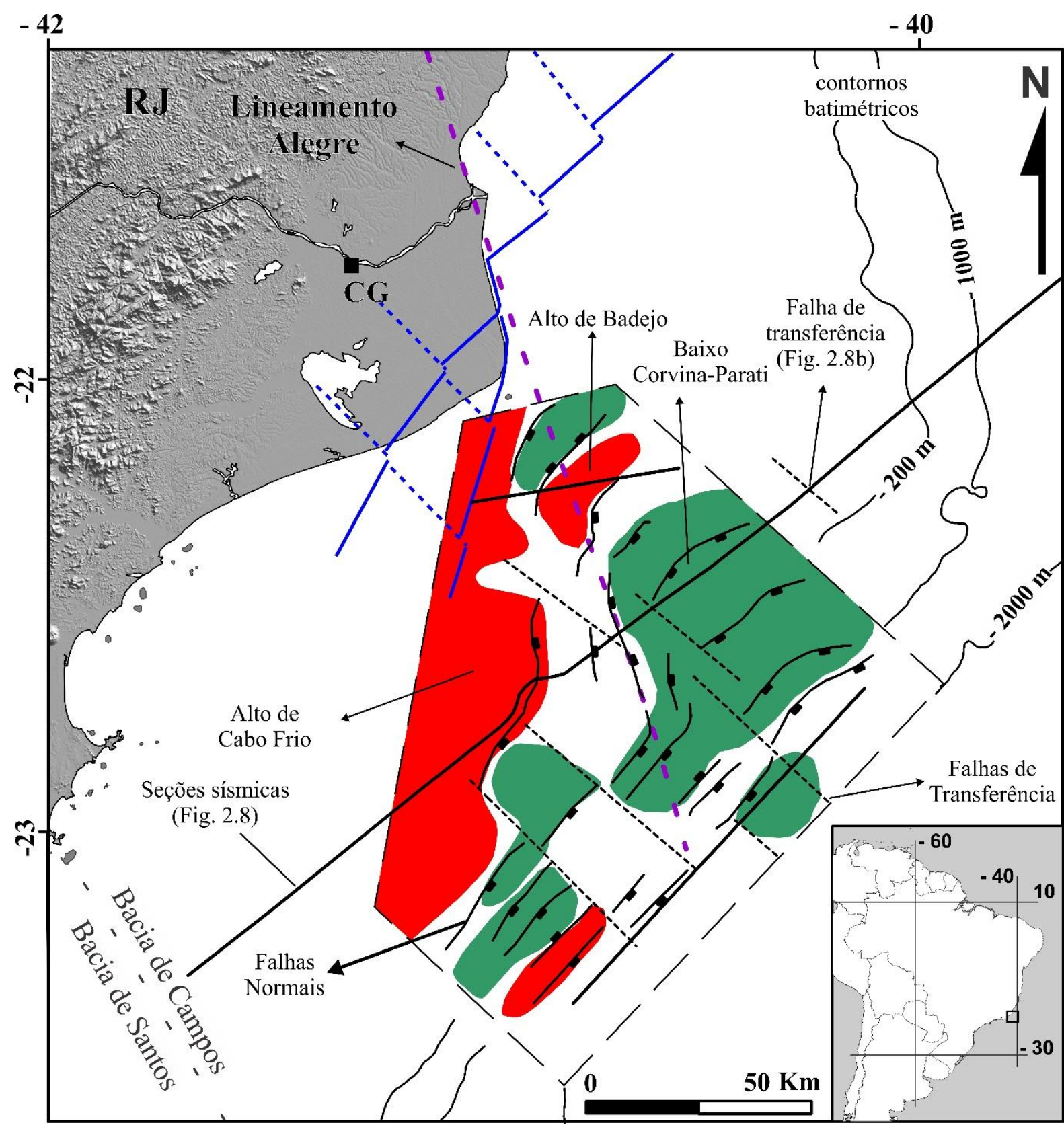

Fig. 2. 11: Mapa dos principais elementos estruturais da região central da Bacia de Campos (áreas em vermelho são altos estruturais e áreas verdes são baixos estruturais). As linhas azuis representam as escarpas da Falha de Campos (linha azul contínua), que sofre escalonamento ao longo de fraturas de direção NW-SE (linhas pontilhadas em azul; dados compilados de Oliveira, 2015). Batimetria extraída de GEBCO (2013), imagem ASTER GDEM de ERSDAC (2013).

A maior parte das falhas normais mapeadas possui direção preferencial NE-SW com mergulho para SE, segmentando altos e baixos estruturais (Fig. 2.11). Essa configuração é resultado dos esforços distensivos que atuaram a partir do Cretáceo Inferior e levaram à formação do Oceano Atlântico, produzindo um sistema de vales rifte alongados na direção NESW, subparalelos às principais estruturas do Embasamento pré-cambriano e controlados por elas (e.g., Dias et al., 1987, 1990; Guardado et al., 1989). Outro aspecto importante do controle NE-SW é destacado por Schaller (1973), que aponta a ação de falhas normais NE-SW 
delimitando os depósitos do Formação Barreiras dos sedimentos quaternários na porção emersa da Bacia de Campos, onde são segmentadas obliquamente por estruturas NW-SE.

As falhas de direção NW-SE (linhas tracejadas em preto; Fig. 2.11) são associadas às falhas de transferência de Cobbold et al. (2001), Meisling et al. (2001), Stanton et al. (2010) e Lourenço et al. (2014), com continuidade para as falhas que escalonam as escarpas da Falha de Campos na direção NW-SE (linhas tracejadas em azul; Fig. 2.11; Oliveira, 2015). Essas falhas, ativas no Cretáceo Inferior, segmentam obliquamente a margem passiva, controlando os blocos formados na fase rifte e os principais depocentros dos sedimentos barremianos, responsáveis pela maioria das reservas petrolíferas da Bacia de Campos (Meisling et al., 2001; Guardado et al., 1989).

A estruturação atribuída ao Lineamento Alegre é marcada por falhamentos normais NNW-SSE, controlando os principais elementos estruturais da bacia. Na região central da área de estudo, as falhas normais associadas à projeção do Lineamento Alegre na bacia delimitam o Baixo Corvina-Parati a ENE, de blocos altos que dão origem ao Alto de Cabo Frio (Fig. 2.11). O Baixo Corvina-Parati coincide, em parte, com o Depocentro Interno da Bacia de Campos identificado por Fetter (2009). O depocentro definido por Fetter (2009) possui origem vinculada à fase rifte e é controlado por falhas de direção NNW-SSE e NE-SW. Próximo à linha de costa, o escalonamento nos planos das escarpas da Falha de Campos ocorre ao longo de fraturas de direção NW-SE e NNW-SSE (Oliveira, 2015). O escalonamento na direção NNW-SSE coincide com o traçado do Lineamento Alegre na Bacia de Campos (Fig. 2.11). Destaca-se ainda que a disposição espacial dos reservatórios do Campo de Namorado (Arienti et al., 1995) se restringe à porção NE da área de atuação do Lineamento Alegre.

\subsection{Integração dos Dados de Superfície e Subsuperfície}

A integração dos dados obtidos em superfície e em subsuperfície revela a influência do Lineamento Alegre na evolução estrutural da porção exposta do Embasamento e na Bacia de Campos.

Os dados de campo coletados na área continental mostram que a atitude da foliação não muda nas proximidades do Lineamento Alegre, mas o traço desta feição delimita os núcleos gabroicos de um granitoide pós-colisional. Sendo assim, a origem dessa estrutura está relacionada ao final do ciclo orogênico Brasiliano-Panafricano (ca. 530-490 Ma; PedrosaSoares et al., 2007). A intrusão de diques básicos alinhados com o traçado do Lineamento 
Alegre indica que esta feição constitui uma zona de fraqueza na crosta submetida a esforços distensivos.

No início da abertura do Oceano Atlântico, no Cretáceo Inferior, o controle do Embasamento na estruturação da bacia costeira e da área continental adjacente foi exercido por descontinuidades pré-existentes que se manifestaram principalmente como falhas normais de direção NE-SW. Essas falhas estão associadas a processos distensivos de direção geral NW-SE que controlaram a geometria dos blocos formados na fase rifte da Bacia de Campos, conforme descrito por vários autores (e.g., Schaller, 1973; Dias et al., 1987, 1990; Guardado et al., 1989; Chang et al., 1992; Stanton et al., 2010). Nesta fase, a estruturação do Lineamento Alegre se manifesta principalmente sob a forma de falhas normais de direção NNW-SSE no continente e na Bacia de Campos. Na área da bacia, essas estruturas controlaram a instalação do Baixo Corvina-Parati, compondo um sistema complexo junto às falhas NE-SW e às zonas de transferência NW-SE, formadas em resposta ao rifteamento durante o Cretáceo Inferior.

No início do Cenozoico, as descontinuidades do Embasamento e aquelas formadas na fase rifte (Cretáceo Inferior), tanto do continente quanto da bacia, foram reativadas por falhas normais de direção geral NE-SW. Essa reativação está associada à movimentação vertical de blocos crustais que resultaram na formação do RCSB (distensão NW-SE a NNW-SSE; Riccomini et al., 1989). Tal evento provocou também nova reativação das descontinuidades preexistentes do Lineamento Alegre sob a forma de falhas normais NNW-SSE. De acordo com as informações obtidas a partir da interpretação sísmica, esses esforços atuaram de forma mais marcante até o final do Paleógeno. No início do Neógeno, ocorreu uma mudança do regime tectônico para um regime transcorrente destral (Hasui, 1990), o que pode ter causado a reativação das falhas de transferência NW-SE na Bacia de Campos (Cobbold et al., 2001).

\subsection{Conclusões}

A análise estrutural realizada no presente trabalho, juntamente com as informações disponíveis na literatura, permitiram concluir que:

a. O Lineamento Alegre atuou, tanto em área continental como em área oceânica, como um conjunto de fraturas de direção NNW-SSE que foram reativadas ao longo do tempo geológico como falhas normais de mesma direção.

b. Na região continental, o Lineamento Alegre é identificado como uma zona de fraturas de direção NNW-SSE formadas no início do Cambriano, que foram reativadas como falhas normais principalmente durante o Cretáceo Inferior e entre o Paleoceno e Oligoceno. 
c. Na área oceânica, o sistema de falhas NNW-SSE associado ao Lineamento Alegre atuou na compartimentação do Baixo Corvina-Parati na fase rifte da bacia, com possibilidades de reativações no início do Paleoceno até o final do Oligoceno, compondo um sistema complexo junto às falhas de transferência NW-SE e às falhas NE-SW.

d. As falhas de transferência identificadas neste estudo possuem direção NW-SE e evidenciam atuação durante a fase rifte da bacia, segmentando blocos altos e baixos delimitados por falhas normais NE-SW. O Lineamento Alegre não se enquadra nos termos conceituais de uma falha de transferência, mas em um conjunto de fraturas de direção NNW-SSE. 


\section{CAPÍTULO III - CONSIDERAÇÕES FINAIS}

\subsection{Conclusões}

A integração dos dados obtidos em superfície (dados de sensoriamento remoto e observações de campo) e em subsuperfície (seções sísmicas 2D e dados de poços) revelou a influência do Lineamento Alegre na evolução estrutural da porção exposta do Embasamento e na Bacia de Campos.

Na região continental, a atitude da foliação não apresenta variação nas proximidades do Lineamento Alegre, mas o traço desta feição delimita os núcleos gabroicos de um granitoide pós-colisional. Tal fato sugere que a origem dessa estrutura se relaciona ao final do ciclo orogênico Brasiliano-Panafricano (ca. 530-490 Ma; Pedrosa-Soares et al., 2007). A intrusão de diques básicos alinhados com o traçado do Lineamento Alegre indica que esta feição constitui uma zona de fraqueza na crosta submetida a esforços distensivos. Embora o posicionamento geocronológico desses diques básicos ainda não esteja bem definido, sua origem pode estar associada aos diques alinhados ao Lineamento Colatina, no norte do Estado do Espírito Santo.

No início da abertura do Oceano Atlântico, Cretáceo Inferior, o controle do Embasamento na estruturação da bacia costeira e da área continental adjacente foi exercido por descontinuidades pré-existentes que se manifestaram principalmente como falhas normais de direção NE-SW. Essas falhas estão associadas a processos distensivos de direção geral NW-SE que controlaram a geometria dos blocos formados na fase rifte da Bacia de Campos, conforme descrito por vários autores (e.g., Schaller, 1973; Dias et al., 1987, 1990; Guardado et al., 1989; Chang et al., 1992; Stanton et al., 2010). Nessa fase, a estruturação do Lineamento Alegre se manifesta principalmente sob a forma de falhas normais de direção NNW-SSE no continente e na Bacia de Campos. Na área da bacia, essas estruturas controlaram a instalação do Baixo Corvina-Parati, compondo um sistema complexo junto às falhas NE-SW e às falhas de transferência NW-SE, formadas em resposta ao rifteamento durante o Cretáceo Inferior. Nesse contexto, é importante ressaltar que o Lineamento Alegre constitui uma descontinuidade préexistente que atuou como uma zona de alívio e, com isso, assume-se que essa feição não se enquadra nos termos conceituais de uma falha de transferência.

No início do Cenozoico, as descontinuidades do Embasamento e aquelas formadas na fase rifte (Cretáceo Inferior), tanto do continente quanto da bacia, foram reativadas por falhas 
normais de direção geral NE-SW. Essa reativação está associada à movimentação vertical de blocos crustais que resultaram na formação do RCSB (distensão NW-SE a NNW-SSE; Riccomini et al., 1989). Tal evento provocou também nova reativação das descontinuidades preexistentes do Lineamento Alegre sob a forma de falhas normais NNW-SSE. De acordo com as informações obtidas a partir da interpretação sísmica, esses esforços atuaram de forma mais marcante até o final do Paleógeno. No início do Neógeno, ocorreu uma mudança do regime tectônico para um regime transcorrente destral (Hasui, 1990), o que pode ter originado juntas NW-SE na região continental e reativação das falhas de transferência NW-SE na Bacia de Campos (Cobbold et al., 2001).

\subsection{Sugestões para Trabalhos Futuros}

A análise estrutural em superfície revelou o importante papel que a trama estrutural e as heterogeneidades presentes no embasamento exercem sobre a evolução geológica regional. Os resultados apresentados possuem implicações importantes para a evolução geológica da região Sudeste do Brasil e na exploração de petróleo na Bacia de Campos. Porém, algumas questões permanecem e existem pontos que carecem de estudos mais específicos. Estão indicados a seguir possíveis temas a serem abordados no futuro, visando ao melhor entendimento da evolução geológica regional:

- Datação dos diques básicos que ocorrem alinhados ao traçado do Lineamento Alegre: as idades dos diques podem indicar com maior precisão o limite inferior da formação do Lineamento Alegre e sua possível relação com os diques encontrados ao longo do traçado do Lineamento Colatina e com os basaltos da Fm. Cabiúnas;

- Datação do material de preenchimento marcado por estrias nos espelhos de falhas: as idades desses materiais podem indicar o limite inferior das reativações das estruturas herdadas do Embasamento pré-cambriano;

- Estudo utilizando dados sísmicos 3D em escala de detalhe na área de atuação do Lineamento Alegre na Bacia de Campos, no limite $\mathrm{W}$ do Baixo Corvina-Parati: o estudo por sísmica 3D pode proporcionar um melhor entendimento das relações entre os processos tectônicos atuantes e a disposição dos reservatórios. O modelo gerado pode indicar com maior precisão a atitude das falhas e o controle tectônico do Embasamento, bem como as reativações associadas. 


\section{REFERÊNCIAS}

Alkmim, F.F., Marshak, S., Pedrosa-Soares, A.C., Peres, G.G., Cruz, S.C.P., Whittington, A., 2006. Kinematic Evolution of the Araçuaí-West Congo orogen in Brazil and Africa: Nutcracker tectonics during the Neoproterozoic assembly of Gondwana. Precambrian Research, 149, 4364.

Alkmim, F.F., Pedrosa-Soares, A.C., Noce, C.M., Cruz, S.C.P., 2007. Sobre a evolução tectônica do Orógeno Araçuaí-Congo Ocidental. Geonomos, 15(1), 25-43.

Almeida, F.F.M. \& Carneiro, C.D.R., 1998. Origem e evolução da Serra do Mar. Revista Brasileira de Geociências, 28(2), 135-150.

Almeida, F.F.M., Brito Neves, B.B., Fuck, R., 1981. Brazilian structural provinces: an introduction. Earth-Science Reviews, 17, 1-29.

Angelier, J. \& Mechler, P., 1977. Sur une méthode graphique de recherche des contraintes principales egalement utilisable en tectonique et en seismologie: la méthode des diédres droits. Bulletin de la Societe Geologique de France, 7, 1309-1318.

ANP, 2014. Agência Nacional do Petróleo - Anuário Estatístico. Disponível em: http://www.anp.gov.br. Acesso em 15 jun. 2015.

Arai, M., 2006. A Grande elevação eustática do Mioceno e sua influência na origem do Grupo Barreiras. Geologia USP, Série Científica, 6(2), 1-6.

Arienti, L.M., Backheuser, Y., Abreu, C.J., Cândido, A., 1995. Estratigrafia e modelo deposicional do Arenito Namorado do Campo de Albacora, Bacia de Campos. Boletim de Geociências da Petrobras, 9(2/4), 249-263.

BDEP, 2013 Banco de Dados de Exploração e Produção. Disponível em http://www.bdep.gov.br. Acesso em 05 abr. 2013.

Belém, J., 2014. Geoquímica, geocronologia e contexto geotectônico do magmatismo máfico associado ao Feixe de Fraturas Colatina, Estado do Espírito Santo. PhD Thesis, Instituto de Geociências, Universidade de Federal de Minas Gerais, 134 p.

Bezerra, F.H.R. \& Vita-Finzi, C., 2000. How active is a passive margin? Paleoseismicity in Northeastern Brasil. Geology, 28, 591-594.

Bezerra, F.H.R., Rossetti, D.F., Oliveira, R.G., Medeiros, W.E, Brito Neves, B.B., Balsamo, F., Nogueira, F.C.C., Dantas, E.L., Andrades Filho, C., Góes, A.M., 2014. Neotectonic reactivation of shear zones and implications for faulting style and geometry in the continental margin of NE Brazil. Tectonophysics, 614, 78-90.

Brito Neves, B.B., 2002. Main Stages of the Development of the Sedimentary Basins of South America and their Relationship with the Tectonics of Supercontinents. Gondwana Research, 5, $175-196$ 
Cainelli, C. \& Mohriak, W. U., 1999. Some remarks on the evolution of sedimentary basins along the Eastern Brazilian continental margin. Episodes, 22, 206-216.

Chang, H.K., Kowsmann, R.O., Figueiredo, A.M.F., Bender, A., 1992. Tectonics and stratigraphy of the East Brazil Rift system: an overview. Tectonophysics, 213, 97-138.

Cobbold, P.R., Meisling, K.R., Mount, V.S., 2001. Reactivation of an obliquely-rifted margin, Campos and Santos basins, Southeastern Brazil. American Association of Petroleum Geologists Bulletin, 85, 1925-1944.

Cunningham, D., Alkmim, F.F., Marshak, S., 1998. A structural transect across the coastal mobile belt in the Brazilian Highlands (latitude 20॰S): the roots of a Precambrian transpressional orogen. Precambrian Research, 92, 251-275.

Davison, I., 1997. Wide and narrow margins of the Brazilian South Atlantic. Journal of the Geological Society of London, 154, 471-476.

De Campos, C.M., Mendes, J.C., Ludka, I.P., Medeiros, S.R., Moura, J.C., Wallfass, C., 2004. A review of the Brasiliano magmatism in southern Espírito Santo, Brazil, with emphasis on post-collisional magmatism. Journal of the Virtual Explorer, 17, 1-35.

Delvaux, D. \& Sperner, B., 2003. Stress tensor inversion from fault kinematic indicators and focal mechanism data: the TENSOR program In: Nieuwland, D.A., (ed.) New Insights into Structural Interpretation and Modelling. Special Publication of the Geological Society of London, 212, 75-100.

Dias, J.F., Guazelli, W., Catto, A.J., Vieira, J.C., 1987. Integração do arcabouço estrutural da Bacia de Campos com o embasamento Pré-Cambriano adjacente. In: I Simpósio de Geologia Regional RJ-ES. Rio de Janeiro, Anais, 189-197.

Dias, J., Scarton, J., Esteves, F., Carminatti, M., Guardado, L., Lincoln, R., 1990. Aspectos da evolução tectono-sedimentar e a ocorrência de hidrocarbonetos na Bacia de Campos In: Gabaglia, G.P.R. \& Milani, E.J., (eds.) Origem e Evolução de Bacias Sedimentares, Petrobras, 333-360.

Dumbar, J.A. \& Sawyer, D S., 1989. How pre-existing weaknesses control the style of continental break-up. Journal of Geophysical Research 94, 7278-7292.

ERSDAC, 2013. Earth Remote Sensing Data Analysis Center (ASTER GDEM). Disponível em: http://gdem.ersdac.jspacesystems.or.jp. Acesso em 10 set. 2013.

Ferrari, A.L., 2001. Evolução Tectônica do Gráben da Guanabara. PhD Thesis, Instituto de Geociências, Universidade de São Paulo, 412 p.

Fetter, M., 2009. The role of basement tectonic reactivation on the structural evolution of Campos Basin, offshore Brazil: Evidence from 3D seismic analysis and section restoration. Marine and Petroleum Geology, 26, 873-886.

GEBCO, 2013. General Bathymetric Chart of the Oceans. Disponível em: http://www.gebco.net/. Acesso em 15 ago. 2013. 
Geobases, 2002. Sistema Integrado de Bases Geoespaciais do Estado do Espírito Santo. INCAPER. Disponível em: http://www.geobases.es.gov.br/portal/. Acesso em: 12 ago 2011.

Gibbs, A.D., 1984. Structural evolution of extensional basin margins. Journal of the Geological Society of London, 141, 609-620.

Grohmann, C.H., Campanha, G.A.C., Soares Junior, A.V., 2011. OpenStereo: um programa Livre e multiplataforma para análise de dados estruturais. In: XIII Simpósio Nacional de Estudos Tectônicos.

Guardado, L.R., Gamboa, L.A.P., Luchesi, C.F., 1989. Petroleum geology of the Campos Basin, a model for a producing Atlantic-type basin. In: Edwards, J. D. \& Santogrossi, P.A., (eds.) Divergent/Passive Margin Basins. American Association of Petroleum Geologists Bulletin, 48, 3-79.

Guardado, L.R., Spadini, A.R., Brandão, J.S.L., Mello, M.R., 2000. Petroleum System of the Campos Basin, Brazil. In: Mello M.R. \& Katz B.J. (eds.) Petroleum systems of South Atlantic margins. American Association of Petroleum Geologists Memoir, 73, 317-324.

Harding, T.P. \& Lowell, J.D., 1979. Structural styles, their plate tectonic habitats, and hydrocarbon traps in petroleum provinces. Association of Petroleum Geologists Bulletin, 63(7), 1016-1058.

Hasui, Y., 1990. Neotectônica e aspectos fundamentais da tectônica ressurgente no Brasil. In: Workshop sobre neotectônica e sedimentação cenozoica continental no Sudeste brasileiro. Belo Horizonte, Anais, p.1-31

Heilbron, M., Pedrosa-Soares, A.C., Campos Neto, M., Silva, L.C., Trouw, R.A.J., Janasi, V.C., 2004. A Província Mantiqueira. In: Mantesso-Neto, V., Bartorelli, A., Carneiro, C.D.R., Brito Neves, B.B. (Eds.). O Desvendar de um Continente: A Moderna Geologia da América do Sul e o Legado da Obra de Fernando Flávio Marques de Almeida. São Paulo, Editora Beca, 13, 203-234.

IBGE, 2005. Instituto Brasileiro de Geografia e Estatística. Projeto Pontos Culminantes: IBGE calcula nova altitude do Monte Roraima. Nota de imprensa atualizada em 29/07/2005. Disponível em: http://www.ibge.gov.br/. Acesso em 20 fev. 2015.

IEMA, 2007. Instituto Estadual de Meio Ambiente e Recursos Hídricos. Levantamento Aerofotogramétrico na escala 1:35000. Disponível em: http://www.meioambiente.es.gov.br. Acesso em: 10 de ago de 2011.

Jelinek, A.R., Chemale, F.Jr., Van der Beek, P.A, Guadagnin, F, Cupertino, J.A, Viana, A., 2014. Denudation history and landscape evolution of the Northern East-Brazilian continental margin from apatite fission-track thermochronology. Journal of South American Earth Sciences, 54, 158-181.

Karniol, T. R. \& Machado, R., 2010. Fluxo tectônico subparalelo ao Cinturão Ribeira no sul do Espírito Santo: análise das estruturas na seção Marechal Floriano-Ibatiba. Revista Brasileira de Geociências, 40(4), 455-467.

Liu, C.C., 1987. A geologia estrutural do Estado do Rio de Janeiro vista através de imagens MSS de Landsat. In: I Simpósio de Geologia Regional RJ-ES. Rio de Janeiro, Anais, 164-188. 
Lourenço, J., Menezes, P.T.L.; Barbosa, V.C.F., 2014. Connecting onshore-offshore Campos basin structures: interpretation of high-resolution airborne magnetic data. Interpretation, 2(4), 181-191.

Meisling, K.E., Cobbold, P.R., Mount, V.S., 2001. Segmentation of an obliquely rifted margin, Campos and Santos basins, Southeastern Brazil. American Association of Petroleum Geologists Bulletin, 85, 1903-1924.

Mello, C.L., 1997. Sedimentação e Tectônica Cenozóicas no Médio Vale do Rio Doce (MG, Sudeste do Brasil) e suas implicações na evolução de um sistema de lagos. PhD Thesis, Instituto de Geociências, Universidade de São Paulo, 275 p.

Mendes, R.S., Neves, M.A., Medeiros Junior, E.B., Rangel, C.V.G.T., 2014. Ocorrências de diques máficos no sul do Estado do Espírito Santo. In: $47^{\circ}$ Congresso Brasileiro de Geologia. Salvador, anais.

Michon, L. \& Sokoutis, D., 2005. Interaction between structural inheritance and extension direction during graben and depocenter formation: an experimental approach. Tectonophysics, 409, 125-146.

Milani, E.J., 1990. Estilo Estruturais em Bacias Sedimentares - Revisão Conceitual. In: Gabalia, G.P.R \& Milani E.J., (eds.) Origem e Evolução de Bacias Sedimentares. Petrobrás, 75-96.

Milani, E.J., Brandão, J.A.S.L., Zalán, P.V., Gamboa, L.A.P., 2000. Petróleo na margem continental brasileira: geologia, exploração, resultados e perspectivas. Brazilian Journal of Geophysics, 18, 351-396.

Mohriak, W.U., Mello, M.R., Dewey, J.F., Maxwell, J.R., 1990. Petroleum geology of the Campos basin, offshore Brazil In: Brooks, J., (ed.) Classic Petroleum Provinces. Special Publication of the Geological Society of London, 50, 119-141.

Mohriak, W.U., 2003. Bacias Sedimentares da Margem Continental Brasileira In: Bizzi, L.A., Schobbenhaus, C., Vidotti, R.M., Gonçalves, J.H., (eds.) Geologia, Tectônica e Recursos Minerais do Brasil. CPRM, Brasília, 3, 87-165.

Mohriak, W.U., 2012. Bacias de Santos, Campos e Espírito Santo In: Hasui, Y., Carneiro, C.D.R., Almeida, F.F.M., Bartorelli, A., (eds.) Geologia do Brasil. São Paulo, Editora Beca, 19b, 481-496.

Morais, R.M.O., Mello, C.L.; Costa, F.O., Santos, P.F., 2006. Fácies sedimentares e ambientes deposicionais associados aos depósitos da formação Barreiras no Estado do Rio de Janeiro. Geologia USP: Série Científica, 6, 19-30.

Novais, L.C.C., Teixeira, L.B., Neves, M.T., Rodarte, J.B.M., Almeida, J.C.H., Valeriano, C.M., 2004. Novas ocorrências de diques de diabásio na faixa Colatina - ES: estruturas rúpteis associadas e implicações tectônicas para as bacias de Campos e do Espírito Santo. Boletim de Geociências da Petrobrás, 12, 191-194.

O’Leary, D.W., Friedman, J.D., Pohn, H.A., 1976. Lineament, linear, lineation: some proposed new standards for old terms. Geological Society of America Bulletin, 87, 1463-1469. 
Oliveira, J.P.M., 2015. Caracterização sismoestrutural do embasamento do Complexo Deltaico do Rio Paraíba do Sul. Ms Dissertation, Instituto de Geociências, Universidade Federal do Rio de Janeiro, 125 p.

Ojeda, H.A.O., 1982. Structural Framework, Stratigraphy, and Evolution of Brazilian Marginal Basins. American Association of Petroleum Geologists Bulletin, 66, 732-749.

Palma, J.J.C., 1984. Fisiografia da área oceânica. In: Schobbenhaus, C., Campos, D. de A., Derze, G.R., Asmus, H.E., (Org.). Geologia do Brasil. Brasília, DF: DNPM, 429-441.

Pedrosa-Soares, A.C., Wiedemann, C.M., Fernandes, M.L.S., De Faria, L.F., Ferreira, J.C.H., 1999. Geotectonic significance of the neoproterozoic granitic magmatism in the Araçuaí Belt, eastern Brazil: a model and pertinent questions. Revista Brasileira de Geociências, 29(1), 5966.

Pedrosa-Soares, A.C. \& Wiedemann-Leonardos, C.M., 2000. Evolution of the Araçuaí Belt and its connection to the Ribeira Belt, Eastern Brazil In: Cordani, U., Milani, E.J., Thomaz-Filho, A., Campos, D.A., (eds.) Tectonic Evolution of South America. São Paulo, Sociedade Brasileira de Geologia, 265-285.

Pedrosa-Soares, A.C., Noce, C.M., Wiedemann, C.M., Pinto, C.P., 2001. The Araçuaí WestCongo Orogen in Brazil: an overview of a confined orogen formed during Gondwana land assembly. Precambrian Research, 110, 307-323.

Pedrosa-Soares, A.C., Noce, C.M., Alkmim, F.F., Silva, L.C., Babinski, M., Cordani, U., Castañeda, C., 2007. Orógeno Araçuaí: síntese do conhecimento 30 anos após Almeida 1977. Geonomos, 15(1), 1-16.

Pedrosa-Soares, A.C., De Campos, C., Noce, C.M., Silva, L.C., Novo, T., Roncato, J., Medeiros, S., Castañeda, C., Queiroga, G., Dantas, E., Dussin, I., Alkmim, F.F., 2011. Late Neoproterozoic-Cambrian granitic magmatism in the Araçuaí orogen (Brazil), the Eastern Brazilian Pegmatite Province and related mineral resources. Special Publication of the Geological Society of London, 350, 25-51.

Ponte, F.C. \& Asmus, H.E., 1978. Geological framework of the Brazilian continental margin. Geologische Rundschau, 67, 201-235.

Rangel, H.D., Martins, F.A.L., Esteves, F.R., Feijó, F.J., 1994. Bacia de Campos. Boletim de Geociências de Petrobras, 8, 203-217.

Riccomini, C., 1997. Arcabouço estrutural e aspectos do tectonismo gerador e deformador da Bacia Bauru no Estado de São Paulo. Revista Brasileira de Geociências, 27, 153-162.

Riccomini, C., Peloggia, A., Saloni, J., Kohnke, M., Figueira, R., 1989. Neotectonic activity in the Serra do Mar rift system (southeastern Brazil). Journal of South American Earth Sciences, 2, 191-197.

Salvador, E.D. \& Riccomini, C., 1995. Neotectônica da região do Alto Estrutural de Queluz (SP-RJ, Brasil). Revista Brasileira de Geociências, 25, 151-164.

Schaller, H., 1973. Estratigrafia da Bacia de Campos in: $27^{\circ}$ Congresso Brasileiro de Geologia. Aracajú, Anais, 3, 247-258. 
Silva, J.N., 1993. Programa Levantamentos Geológicos Básicos do Brasil. Cachoeiro de Itapemirim. Folha SF.24-V-A-V. Estado do Espírito Santo. Escala 1:100.000. Brasília: DNPM/CPRM. 165 p.

Silva, J.M.R., Lima, M.I.C., Veronese, V.F., Ribeiro, Jr.R.N., Rocha, R.M., Siga, Jr.O., 1987. Geologia. In: Projeto RADAMBRASIL - Folha SE 24 Rio Doce: geologia, geomorfologia, pedologia, vegetação, uso potencial da terra. Rio de Janeiro. Departamento Nacional da Produção Mineral (DNPM), 34, 1v. + 6 mapas.

Silva, M.A., Camozzato, E., Paes, V.J.C., Junqueira, P.A., Ramgrab, G. E., 2004. Folha SF.24Vitoria. In: Schobbenhaus C., Gonçalves J.H., Santos J.O.S., Abram M.B., Leão Neto R., Matos G.M.M., Vidotti R.M., Ramos M.A.B., Jesus J.D.A. de. (eds.). Carta Geológica do Brasil ao Milionésimo, Sistema de Informações Geográficas. Programa Geologia do Brasil. CPRM, Brasília. CD-ROM.

Silva, T.P. da \& Mello, C.L., 2011. Reativações Neotectônicas na Zona de Cisalhamento do Rio Paraíba do Sul (Sudeste do Brasil). Geologia USP, Série Científica, 11(1), 95-111.

Söllner, F., Lammerer, B., Wiedemann, C.M., 2000. Dating the Ribeira Mobile Belt of Brazil. Sonderheft Zeitschrift für Angewandte Geologie, 245-255.

Souza, I.A., Ebert, H.D., Castro, J.C., Soares, Jr.A.V., Silva, G.H.T., Benvenutti, C.F., 2009. Caracterização das falhas de transferência na porção norte da Bacia de Santos a partir da integração de dados geológicos e geofísicos. Boletim de Geociências da Petrobrás, 17(1), 109132.

Stampfli, G.M., Hochard, C., Vérard, C., Wilhem, C., VonRaumer, J., 2013. The formation of Pangea. Tectonophysics, 593, 1-19.

Stanton, N., Schmitt, R.S., Galdeano, A., Maia, M., Mane, M., 2010. Crustal structure of the southeastern Brazilian Margin from aeromagnetic data: new kinematic constraints. Tectonophysics, 490, 15-27.

Torsvik, T.H. \& Cocks, L.R.M., 2013. Gondwana from top to base in space and time. Gondwana Research, 24, 999-1030.

Trompette, R., Egydio-Silva, M., Tommasi, A., Vauchez, A., Uhlein, A., 1993. Amalgamação do Gondwana Ocidental no Panafricano-Brasiliano e o papel da geometria do cráton do São Francisco na arquitetura da faixa Ribeira. Revista Brasileira de Geociências, 23, 187-193.

Valente, S.C., Dutra, T., Heilbron, M., Corval, A., Szatmari, P., 2009. Litogeoquímica de Diques de Diabásio da Faixa de Colatina, ES. Geochimica Brasiliensis, 23, 177-192.

Veevers, J.J., 2004. Gondwanaland from 650-500 Ma assembly through 320 Ma merger in Pangea to 185-100 Ma breakup: supercontinental tectonics via stratigraphy and radiometric dating. Earth-Science Reviews, 68, 1-132

Vieira, V.S., 1997. Programa Levantamentos Geológicos Básicos do Brasil - Folha Cachoeiro de Itapemirim. Folha SF.24-V-A. Estado do Espírito Santo. Escala 1:250.000. DNPM/CPRM. Brasília, 110p. 
Vieira, V.S., Silva, M.A., Corrêa, T. R., Lopes, M.H.B., 2014. Mapa Geológico do Espírito Santo - Escala 1:400.000. In: VI Simexmin - Simpósio Brasileiro de Exploração Mineral, Ouro Preto.

Vincentelli, M.G.C., 2013. Deformação tectônica do Cenozoico da Bacia de Campos, como formador de campos de hidrocarboneto. In: XIV Simpósio Nacional de Estudos Tectônicos e VII International Symposium on Tectonics, anais.

Wiedemann-Leonardos, C.M., Ludka, I.P., Medeiros, S.R., Mendes, J.C., Costa-de-Moura, J., 2000. Arquitetura de plútons zonados da faixa Araçuaí-Ribeira. Geonomos, 8, 25-38.

Wiedemann, C.M., Campos, C.M., Medeiros, S.R., Mendes, J.C., Ludka, I.P., Moura, J.C., 2002. Architecture of Late orogenic Plutons in the Araçuaí-Ribeira Folded Belt, Southeast Brazil. Gondwana Research, 19, 381-399.

Wilson, R.W., 2005. Basement control on faulting patterns, transtension and structural segmentation of the Lofoten Ridge, Norwegian Margin: using digital mapping to link onshore and offshore geology. Midland Valley Prize, 1-20.

Winter, W.R., Jahnert, R.J., França, A.B., 2007. Bacia de Campos. Boletim de Geociências da Petrobras, 15(2), 511-529.

Zalán, P.V., 1986. Identificação de falhas transcorrentes em seções sísmicas. Revista Brasileira de Geociências, 16(3), 258-265.

Zalán, P. V. \& Oliveira, J.A.B., 2005. Origem e evolução estrutural do Sistema de Riftes Cenozóicos do Sudeste do Brasil. Boletim de Geociências da Petrobras, 13(2), 269-300. 


\section{APÊNDICE A - SEÇÕES SÍSMICAS 2D INTERPRETADAS}

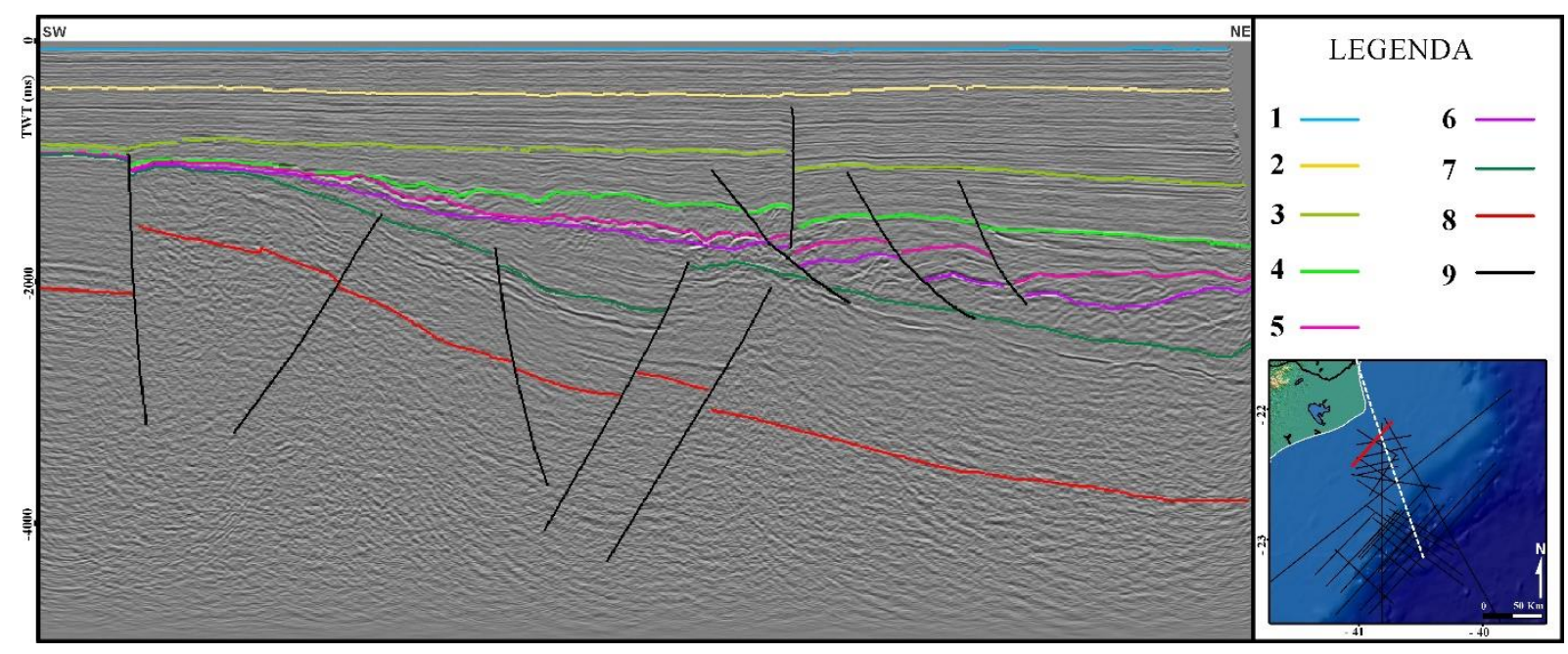

Apêndice A.1: Seção sísmica 2D interpretada, segmento 0038-0241. 1 = Topo da Sequência Mioceno-Pleistoceno, 2 = Topo da Sequência Paleoceno-Oligoceno, 3 = Topo da Sequência Cenomaniano-Maastrichtiano, $4=$ Topo do Albiano, 5 = Topo do Sal, 6 = Topo da Sequência Pós-Rifte, 7 = Topo da Sequência Rifte, $8=$ Embasamento, $9=$ Falhas.

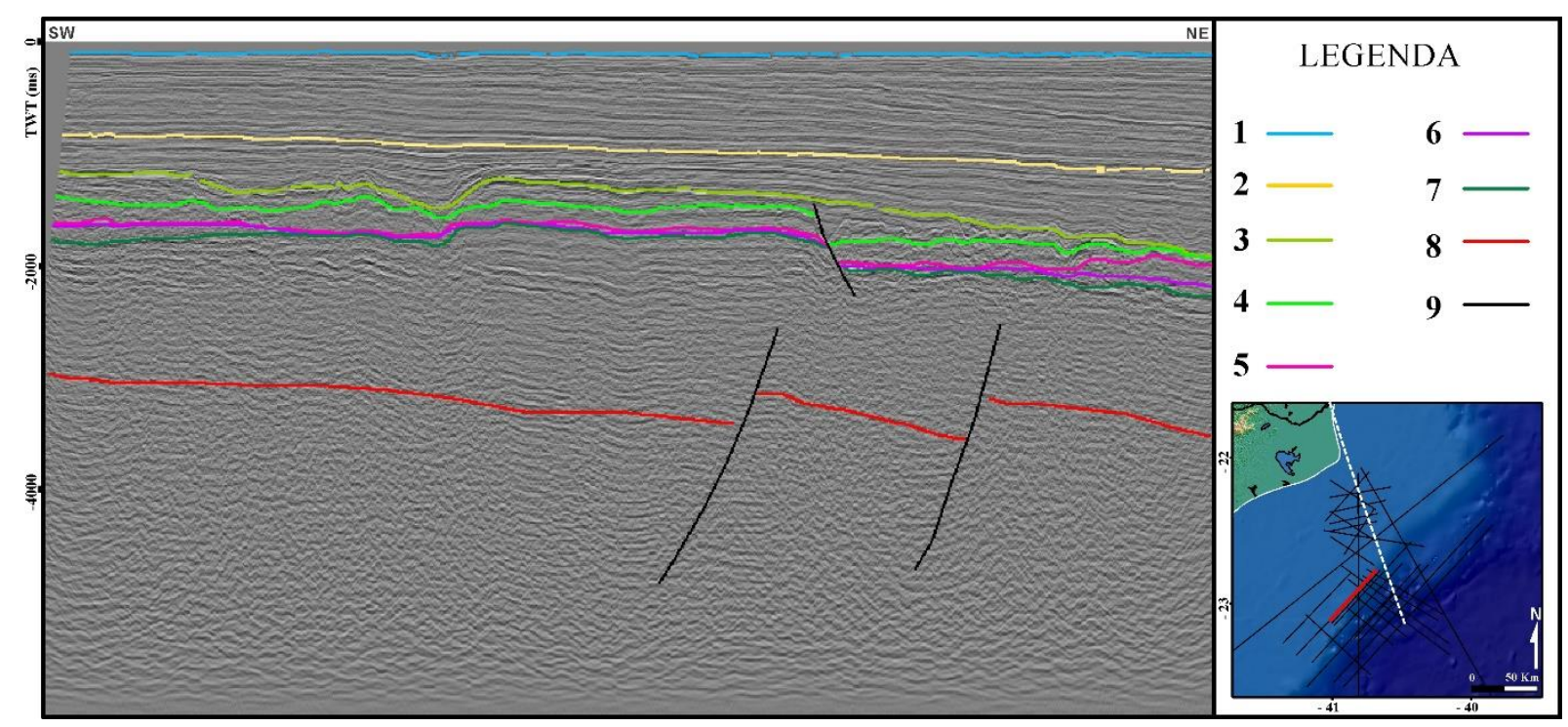

Apêndice A.2: Seção sísmica 2D interpretada, segmento 0046-0118. 1 = Topo da Sequência Mioceno-Pleistoceno, 2 = Topo da Sequência Paleoceno-Oligoceno, 3 = Topo da Sequência Cenomaniano-Maastrichtiano, $4=$ Topo do Albiano, 5 = Topo do Sal, 6 = Topo da Sequência Pós-Rifte, 7 = Topo da Sequência Rifte, $8=$ Embasamento, $9=$ Falhas. 


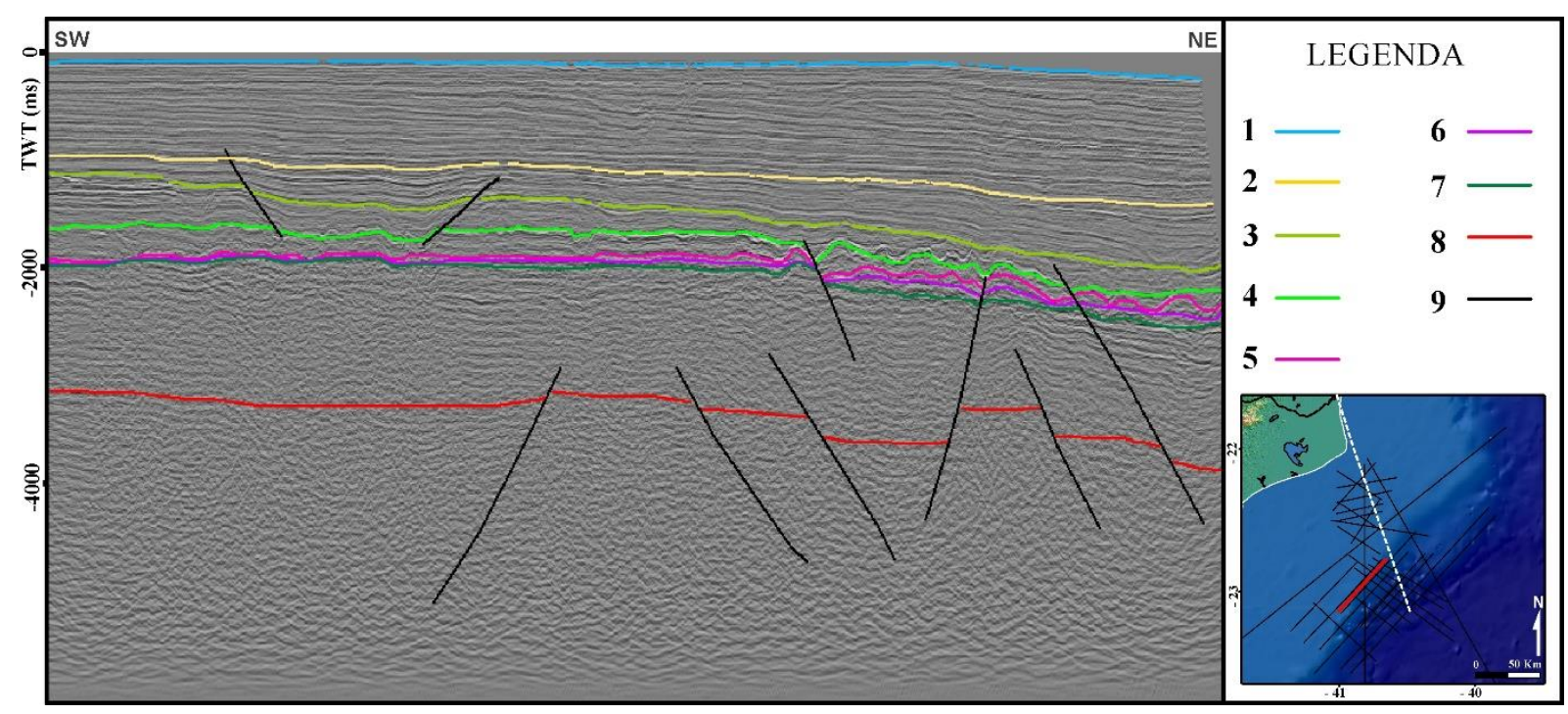

Apêndice A.3: Seção sísmica 2D interpretada, segmento 0046-0120. 1 = Topo da Sequência Mioceno-Pleistoceno, 2 = Topo da Sequência Paleoceno-Oligoceno, 3 = Topo da Sequência Cenomaniano-Maastrichtiano, $4=$ Topo do Albiano, 5 = Topo do Sal, 6 = Topo da Sequência Pós-Rifte, 7 = Topo da Sequência Rifte, $8=$ Embasamento, $9=$ Falhas.

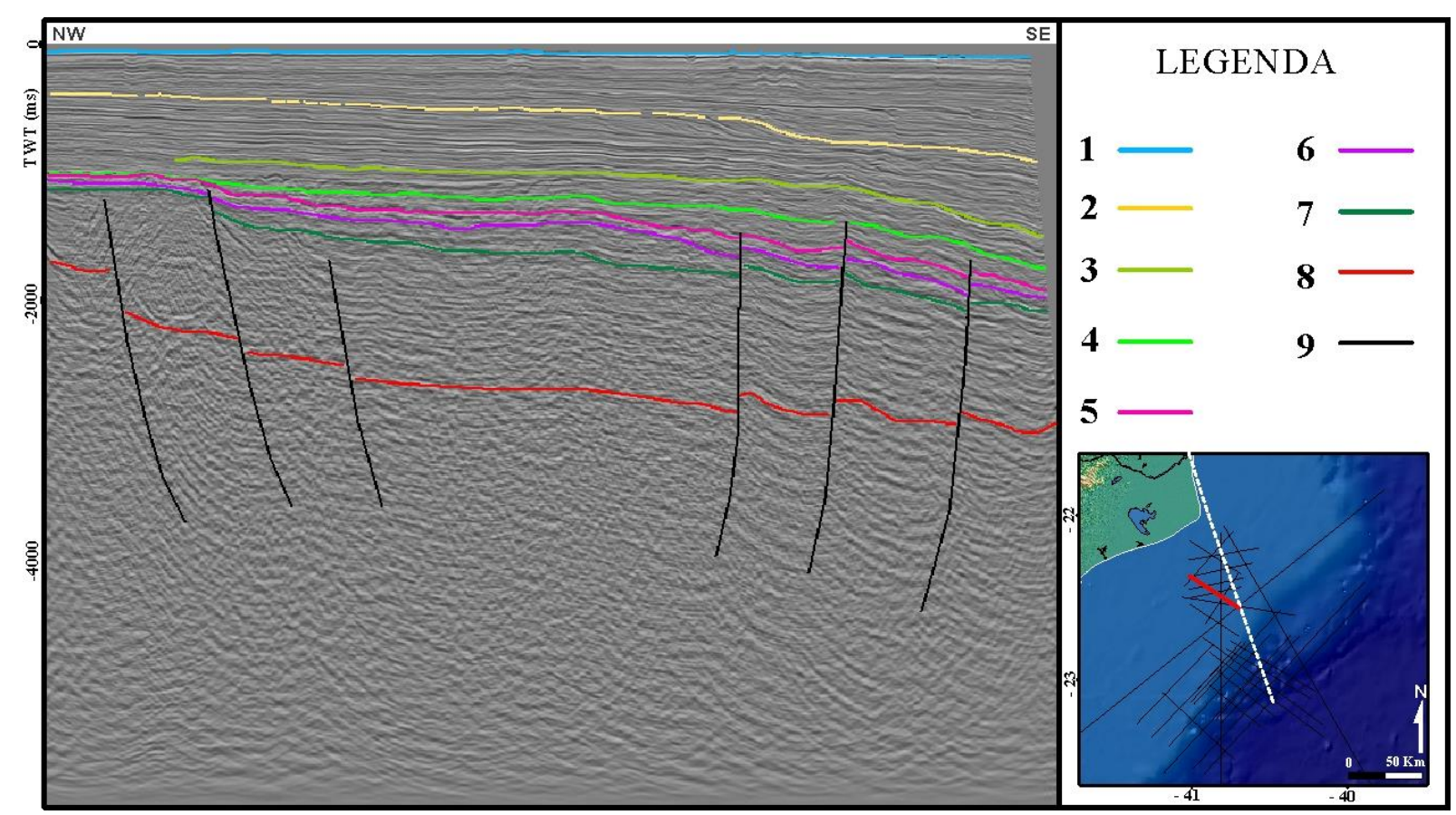

Apêndice A.4: Seção sísmica 2D interpretada, segmento 0067-0489. 1 = Topo da Sequência Mioceno-Pleistoceno, 2 = Topo da Sequência Paleoceno-Oligoceno, 3 = Topo da Sequência Cenomaniano-Maastrichtiano, $4=$ Topo do Albiano, 5 = Topo do Sal, 6 = Topo da Sequência Pós-Rifte, 7 = Topo da Sequência Rifte, $8=$ Embasamento, $9=$ Falhas. 


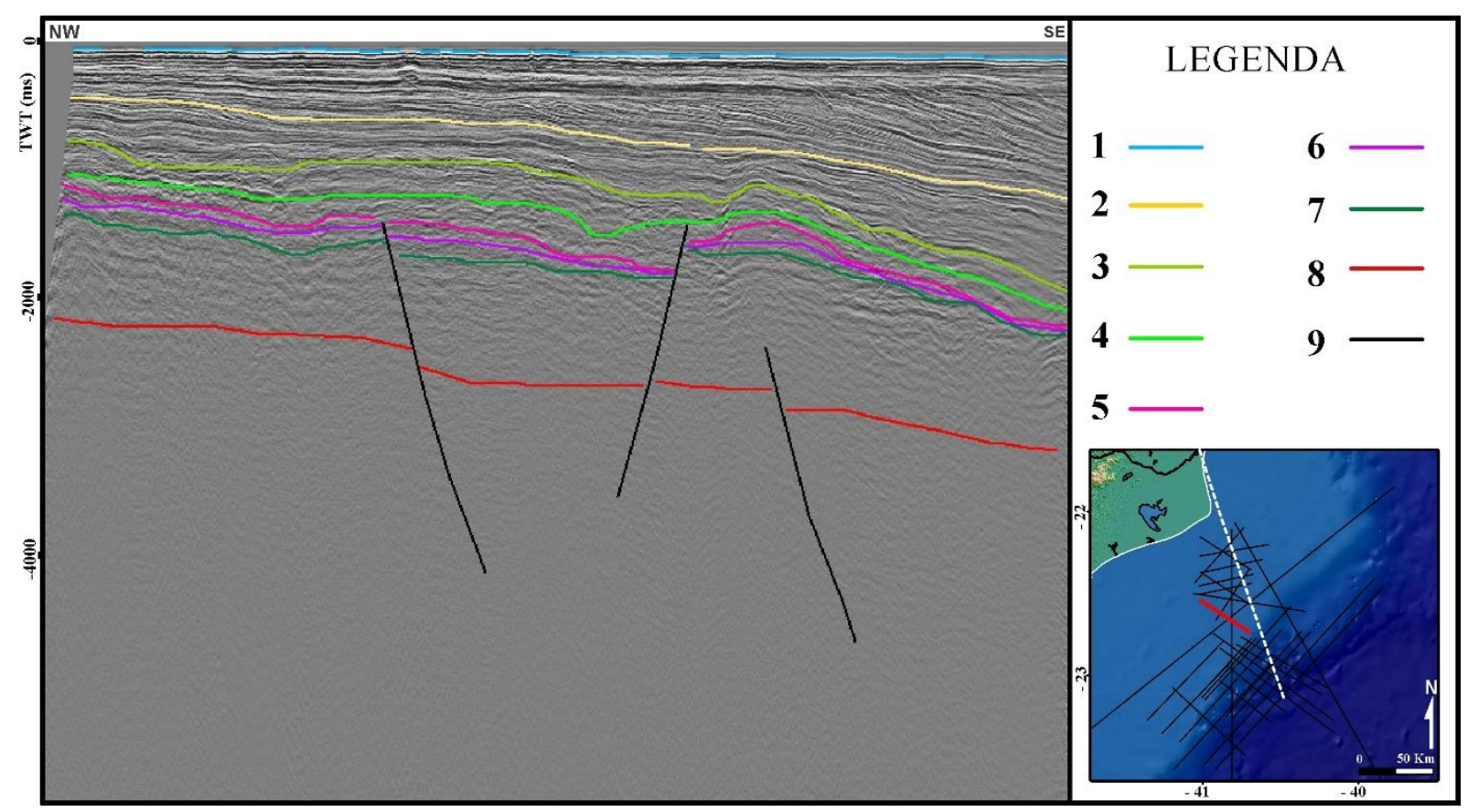

Apêndice A.5. Seção sísmica 2D interpretada, segmento 0067-0497. 1 = Topo da Sequência Mioceno-Pleistoceno, 2 = Topo da Sequência Paleoceno-Oligoceno, 3 = Topo da Sequência Cenomaniano-Maastrichtiano, $4=$ Topo do Albiano, 5 = Topo do Sal, 6 = Topo da Sequência Pós-Rifte, 7 = Topo da Sequência Rifte, $8=$ Embasamento, $9=$ Falhas.

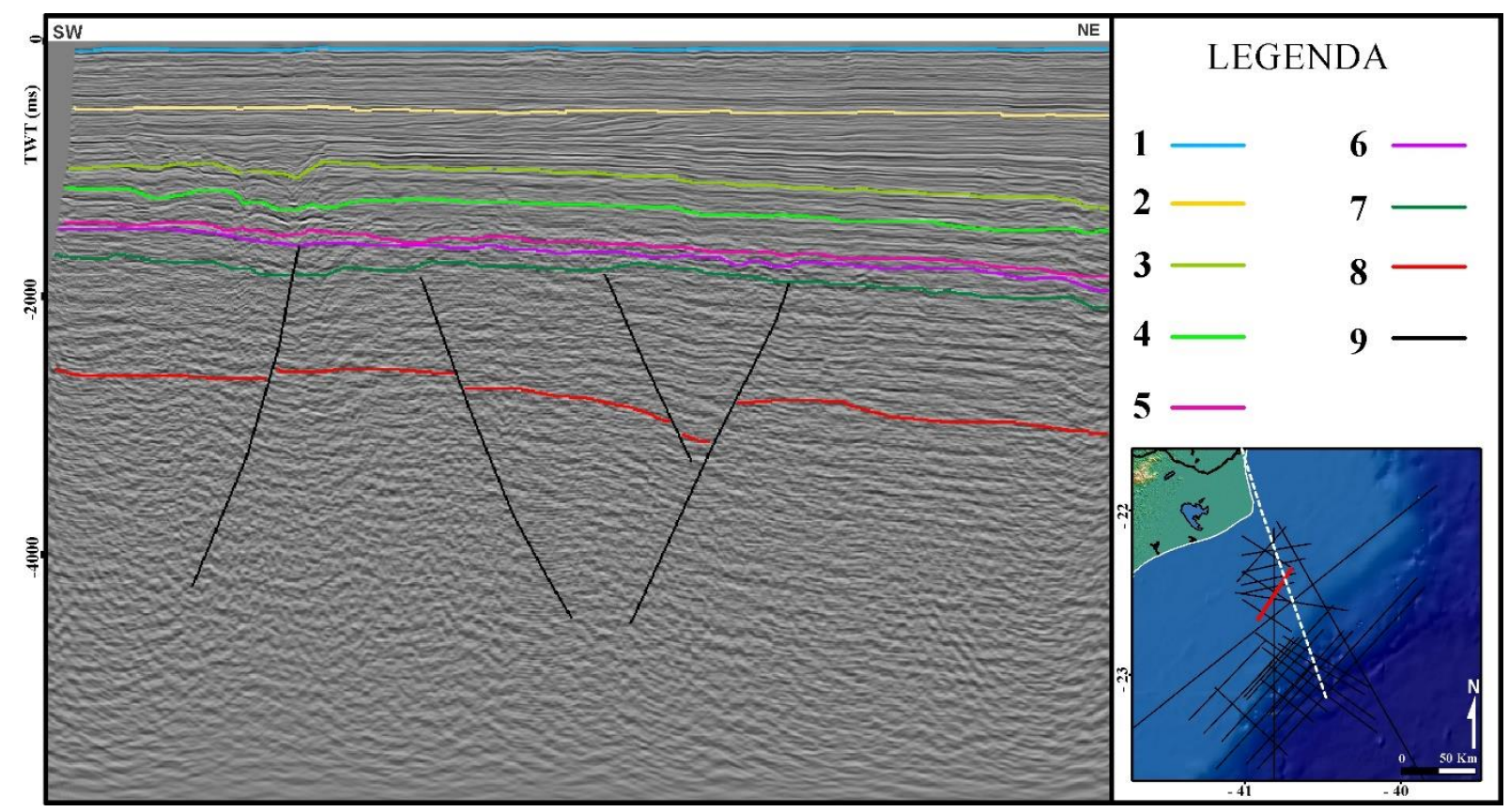

Apêndice A.6: Seção sísmica 2D interpretada, segmento 0067-0524. 1 = Topo da Sequência Mioceno-Pleistoceno, 2 = Topo da Sequência Paleoceno-Oligoceno, 3 = Topo da Sequência Cenomaniano-Maastrichtiano, $4=$ Topo do Albiano, 5 = Topo do Sal, 6 = Topo da Sequência Pós-Rifte, 7 = Topo da Sequência Rifte, $8=$ Embasamento, $9=$ Falhas. 


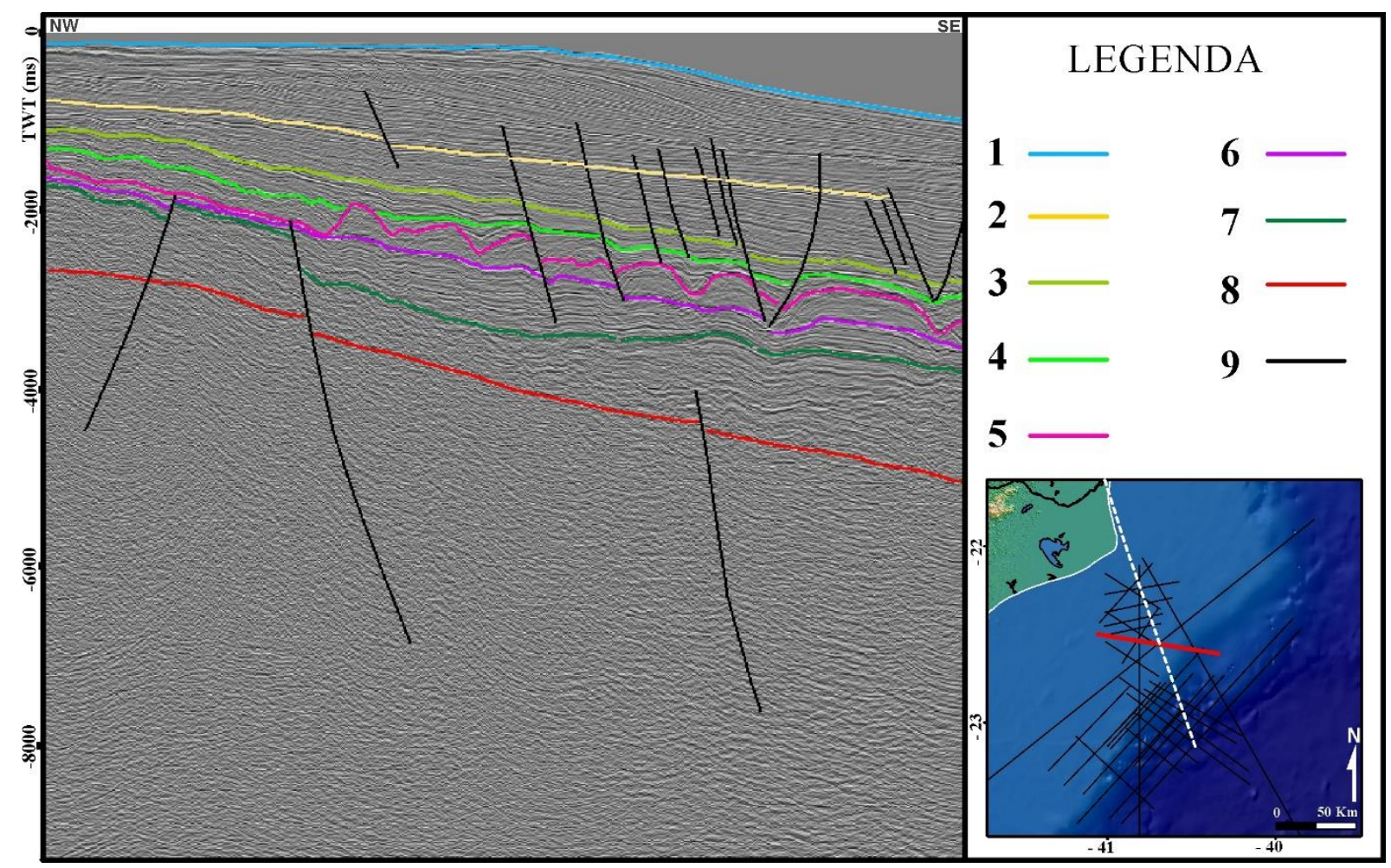

Apêndice A.7: Seção sísmica 2D interpretada, segmento 0203-0079. 1 = Topo da Sequência Mioceno-Pleistoceno, 2 = Topo da Sequência Paleoceno-Oligoceno, 3 = Topo da Sequência Cenomaniano-Maastrichtiano, $4=$ Topo do Albiano, 5 = Topo do Sal, 6 = Topo da Sequência Pós-Rifte, 7 = Topo da Sequência Rifte, $8=$ Embasamento, $9=$ Falhas.

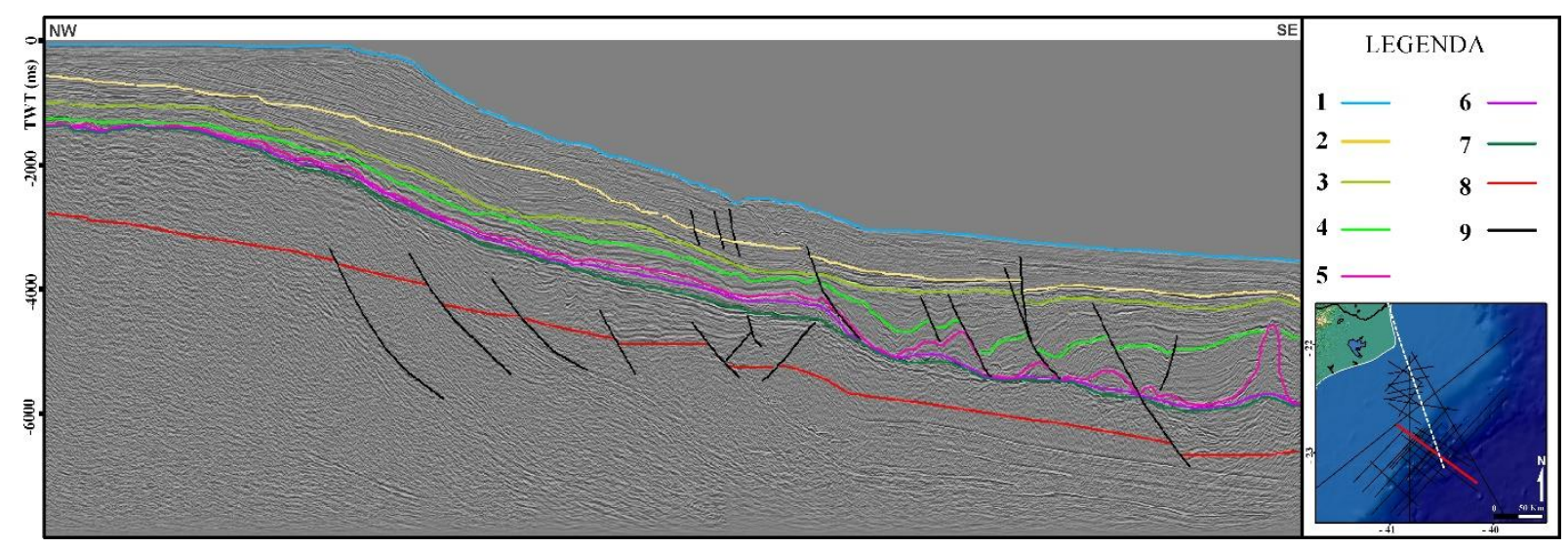

Apêndice A.8: Seção sísmica 2D interpretada, segmento 0214-0189. 1 = Topo da Sequência Mioceno-Pleistoceno, 2 = Topo da Sequência Paleoceno-Oligoceno, $3=$ Topo da Sequência Cenomaniano-Maastrichtiano, $4=$ Topo do Albiano, 5 = Topo do Sal, 6 = Topo da Sequência Pós-Rifte, 7 = Topo da Sequência Rifte, $8=$ Embasamento, $9=$ Falhas. 


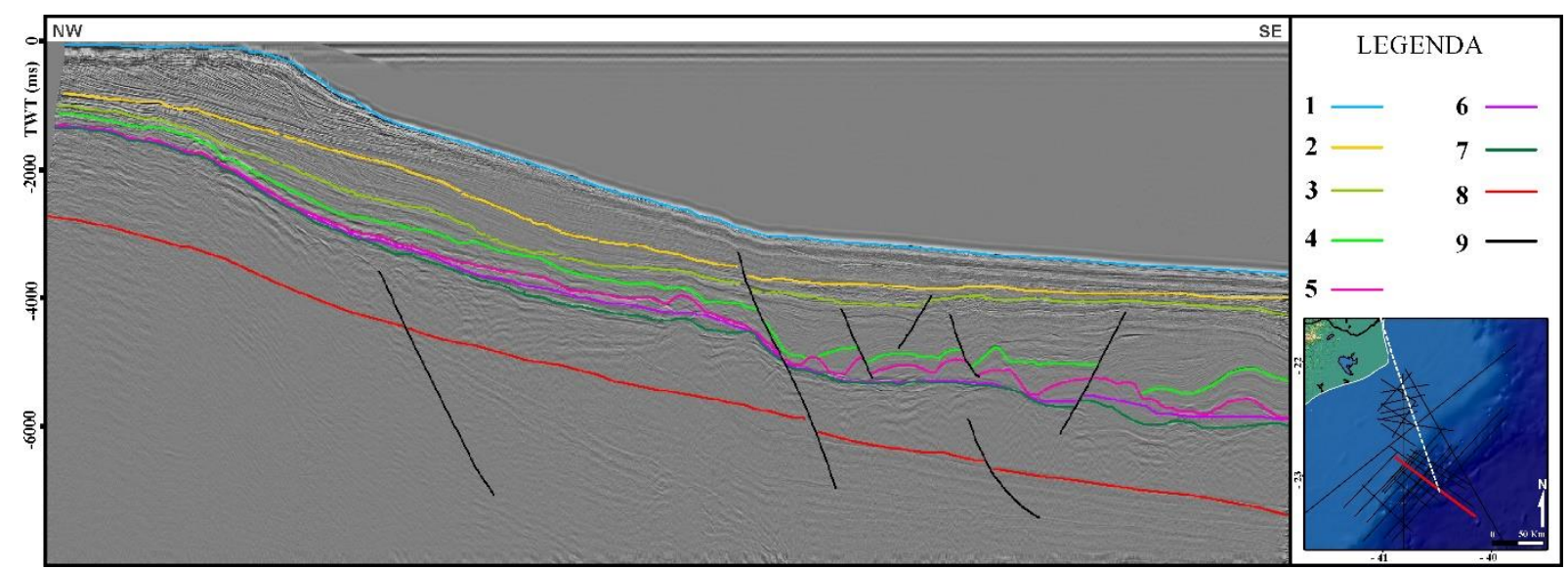

Apêndice A.9: Seção sísmica 2D interpretada, segmento 0214-0191. 1 = Topo da Sequência Mioceno-Pleistoceno, 2 = Topo da Sequência Paleoceno-Oligoceno, 3 = Topo da Sequência Cenomaniano-Maastrichtiano, 4 = Topo do Albiano, 5 = Topo do Sal, 6 = Topo da Sequência Pós-Rifte, 7 = Topo da Sequência Rifte, $8=$ Embasamento, $9=$ Falhas.

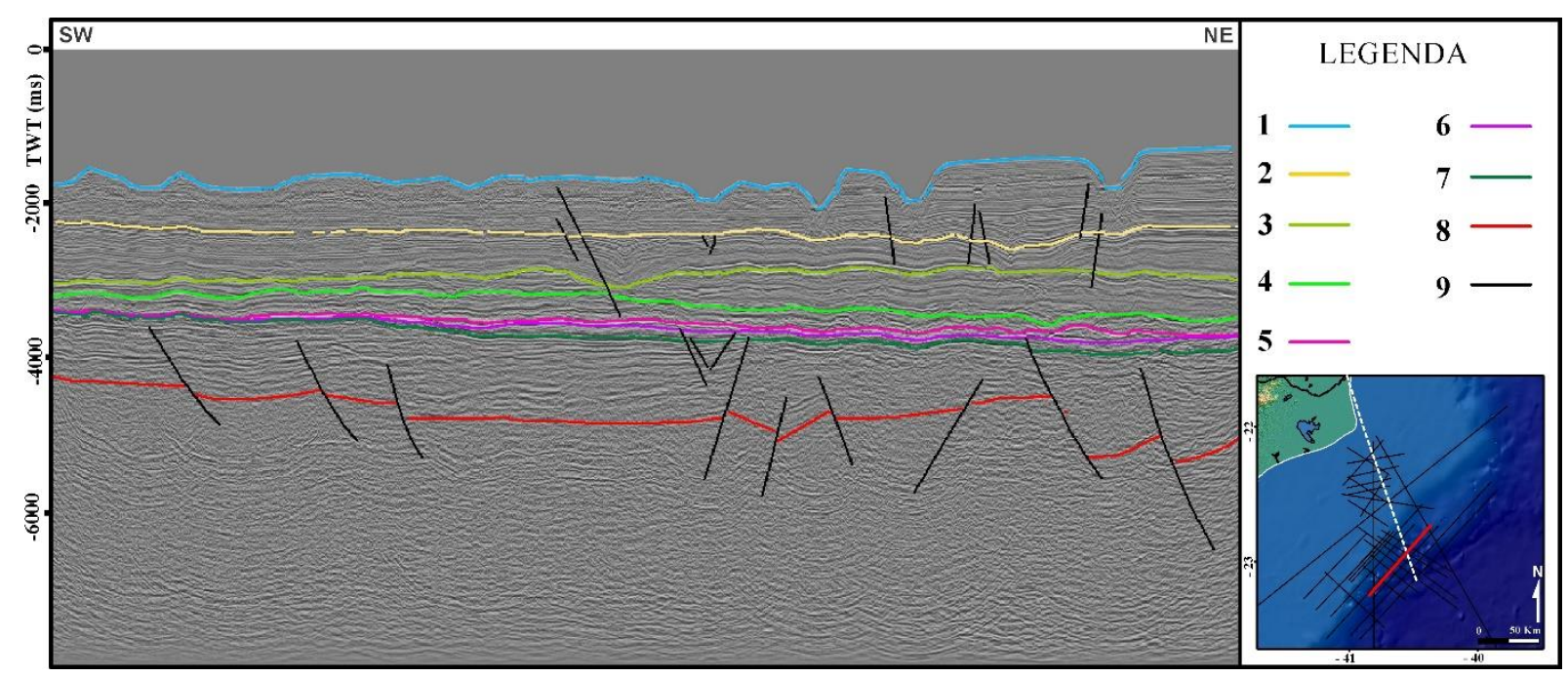

Apêndice A.10: Seção sísmica 2D interpretada, segmento 0214-0198. 1 = Topo da Sequência MiocenoPleistoceno, 2 = Topo da Sequência Paleoceno-Oligoceno, 3 = Topo da Sequência Cenomaniano-Maastrichtiano, 4 = Topo do Albiano, 5 = Topo do Sal, 6 = Topo da Sequência Pós-Rifte, 7 = Topo da Sequência Rifte, $8=$ Embasamento, 9 = Falhas. 


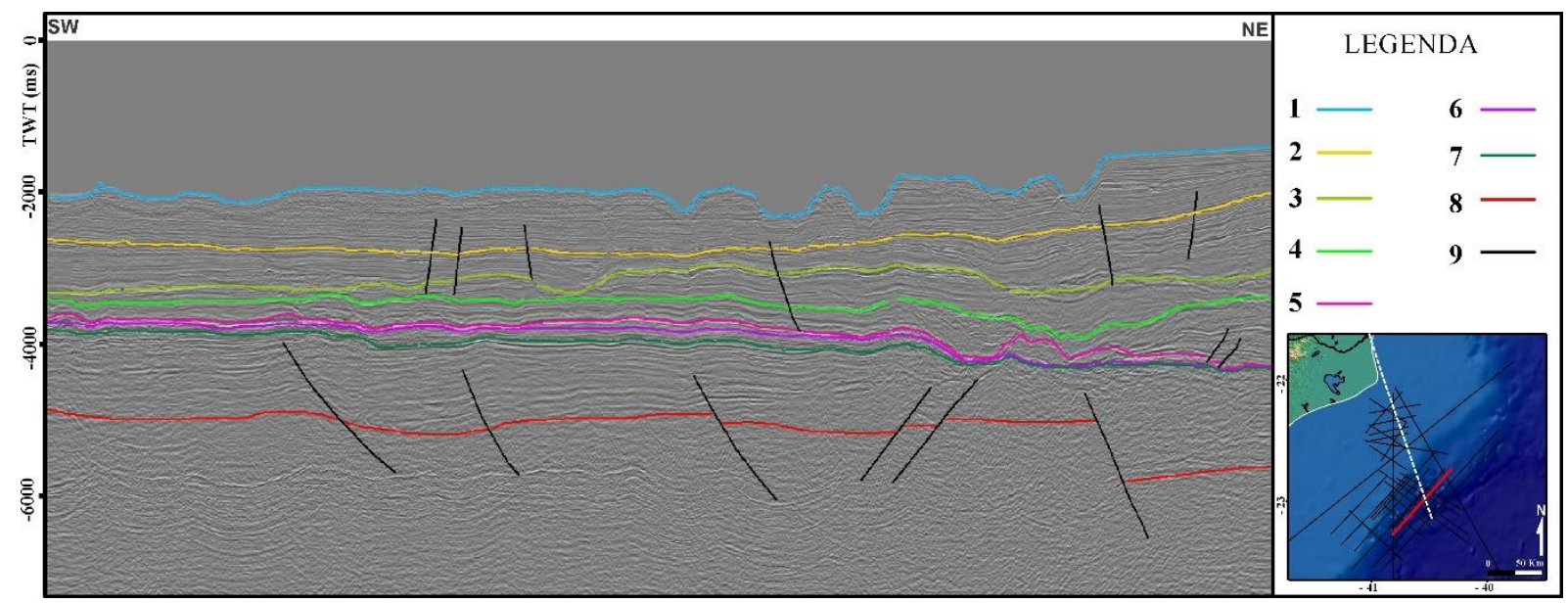

Apêndice A.11: Seção sísmica 2D interpretada, segmento 0214-0199. 1 = Topo da Sequência MiocenoPleistoceno, 2 = Topo da Sequência Paleoceno-Oligoceno, 3 = Topo da Sequência Cenomaniano-Maastrichtiano, 4 = Topo do Albiano, 5 = Topo do Sal, 6 = Topo da Sequência Pós-Rifte, 7 = Topo da Sequência Rifte, 8 = Embasamento, $9=$ Falhas.

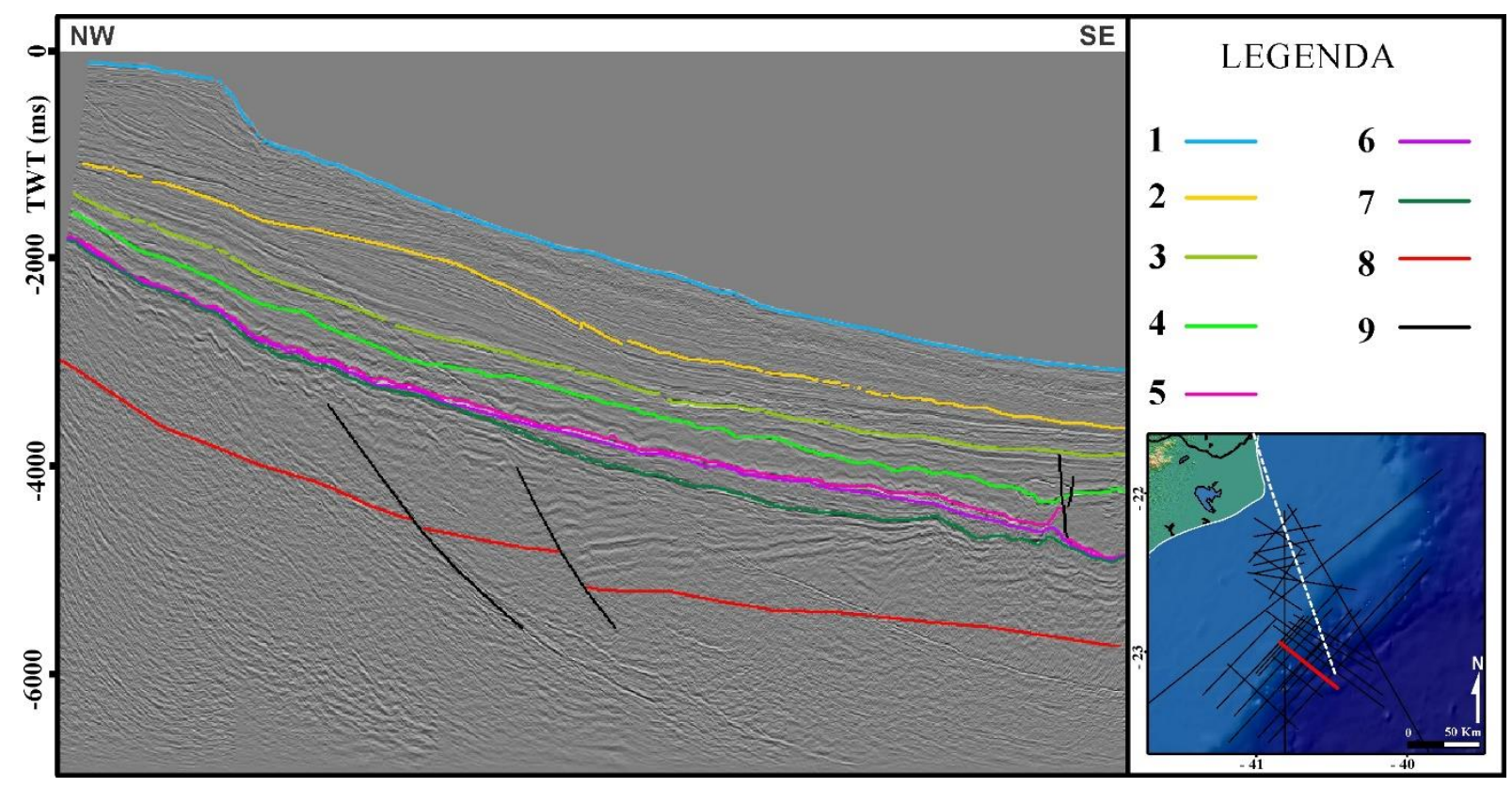

Apêndice A.12: Seção sísmica 2D interpretada, segmento 0221-6710. 1 = Topo da Sequência MiocenoPleistoceno, 2 = Topo da Sequência Paleoceno-Oligoceno, 3 = Topo da Sequência Cenomaniano-Maastrichtiano, 4 = Topo do Albiano, $5=$ Topo do Sal, 6 = Topo da Sequência Pós-Rifte, 7 = Topo da Sequência Rifte, $8=$ Embasamento, $9=$ Falhas. 


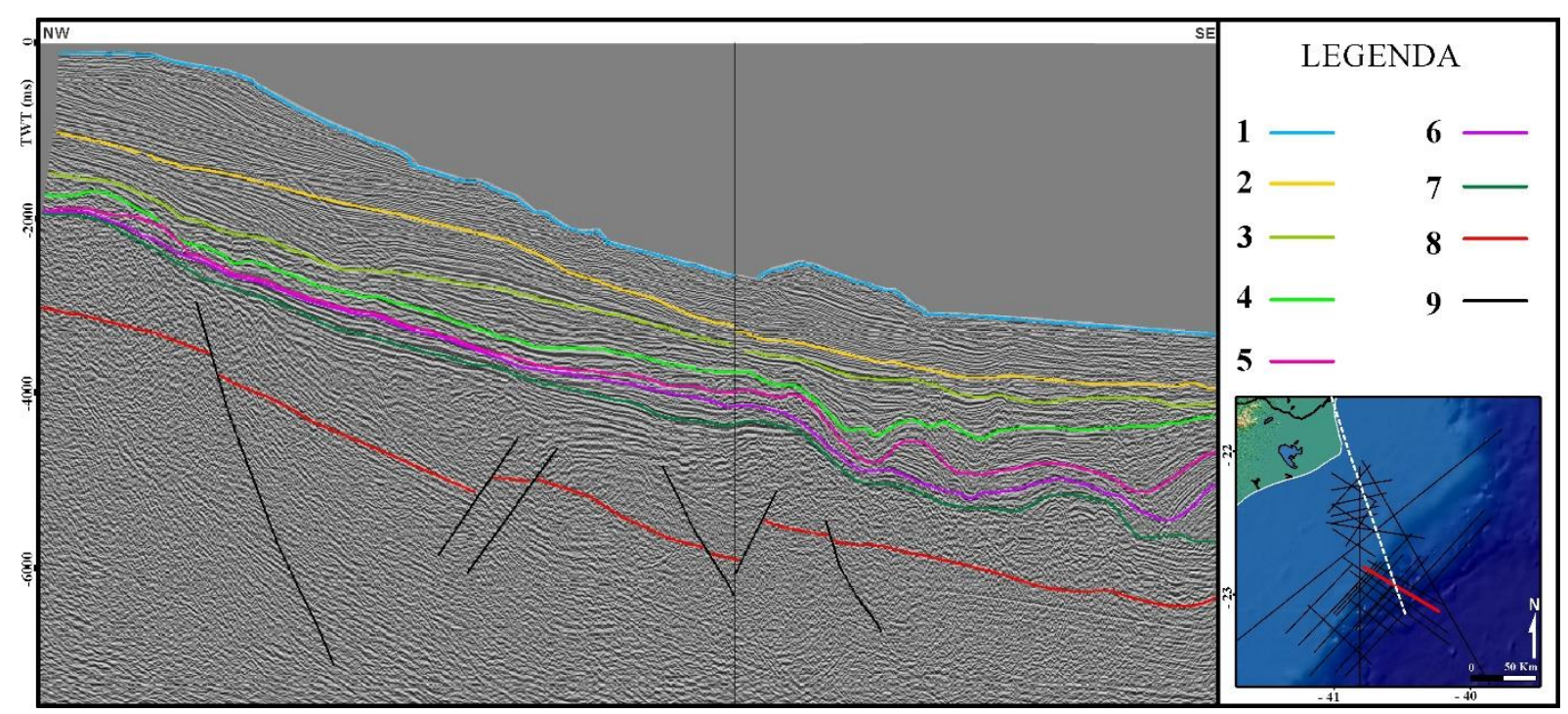

Apêndice A.13: Seção sísmica 2D interpretada, segmento 0228-0333. 1 = Topo da Sequência MiocenoPleistoceno, 2 = Topo da Sequência Paleoceno-Oligoceno, 3 = Topo da Sequência Cenomaniano-Maastrichtiano, 4 = Topo do Albiano, 5 = Topo do Sal, 6 = Topo da Sequência Pós-Rifte, 7 = Topo da Sequência Rifte, $8=$ Embasamento, 9 = Falhas.

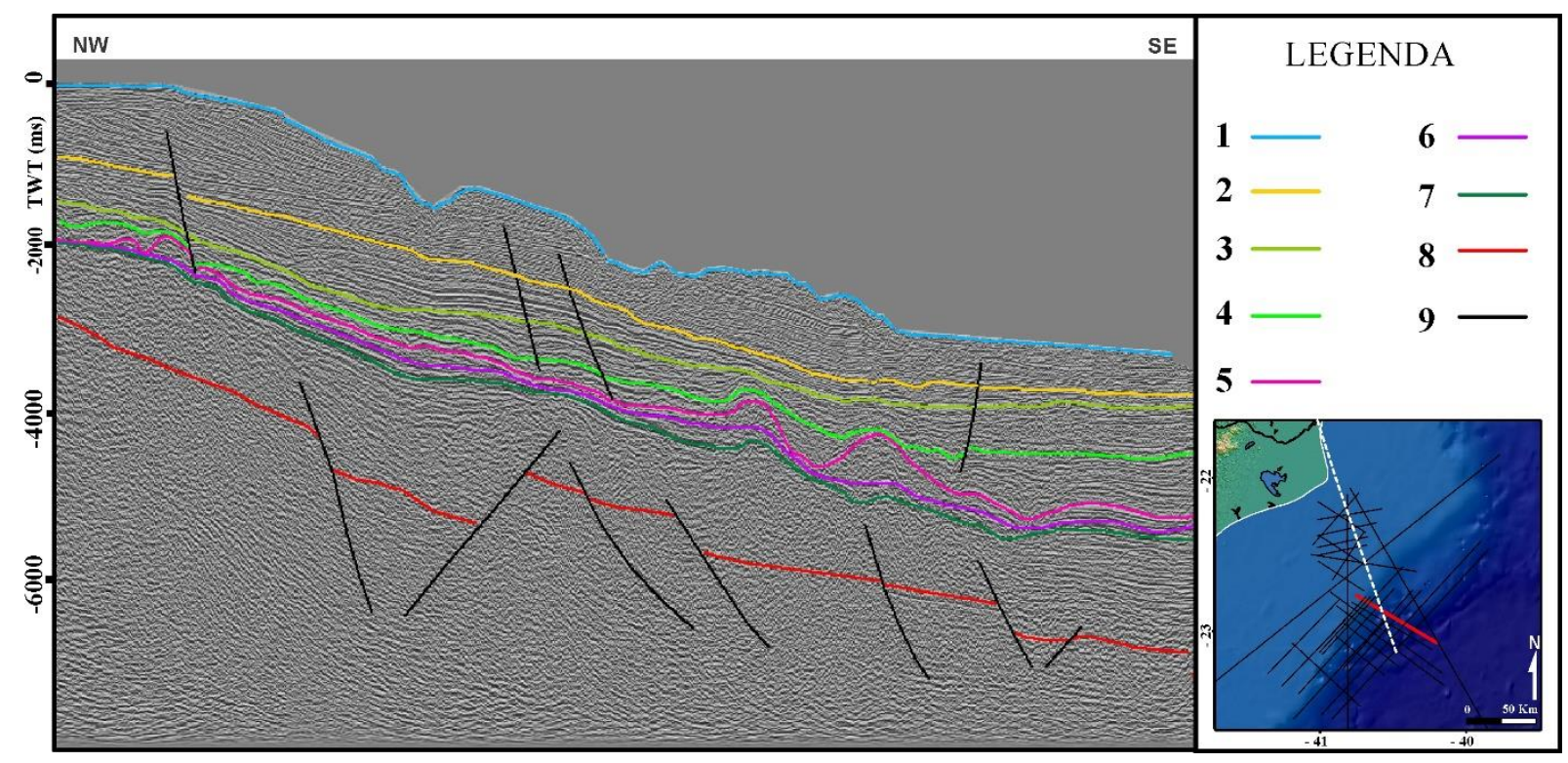

Apêndice A.14: Seção sísmica 2D interpretada, segmento 0228-0341. 1 = Topo da Sequência MiocenoPleistoceno, 2 = Topo da Sequência Paleoceno-Oligoceno, 3 = Topo da Sequência Cenomaniano-Maastrichtiano, 4 = Topo do Albiano, 5 = Topo do Sal, 6 = Topo da Sequência Pós-Rifte, 7 = Topo da Sequência Rifte, $8=$ Embasamento, $9=$ Falhas. 


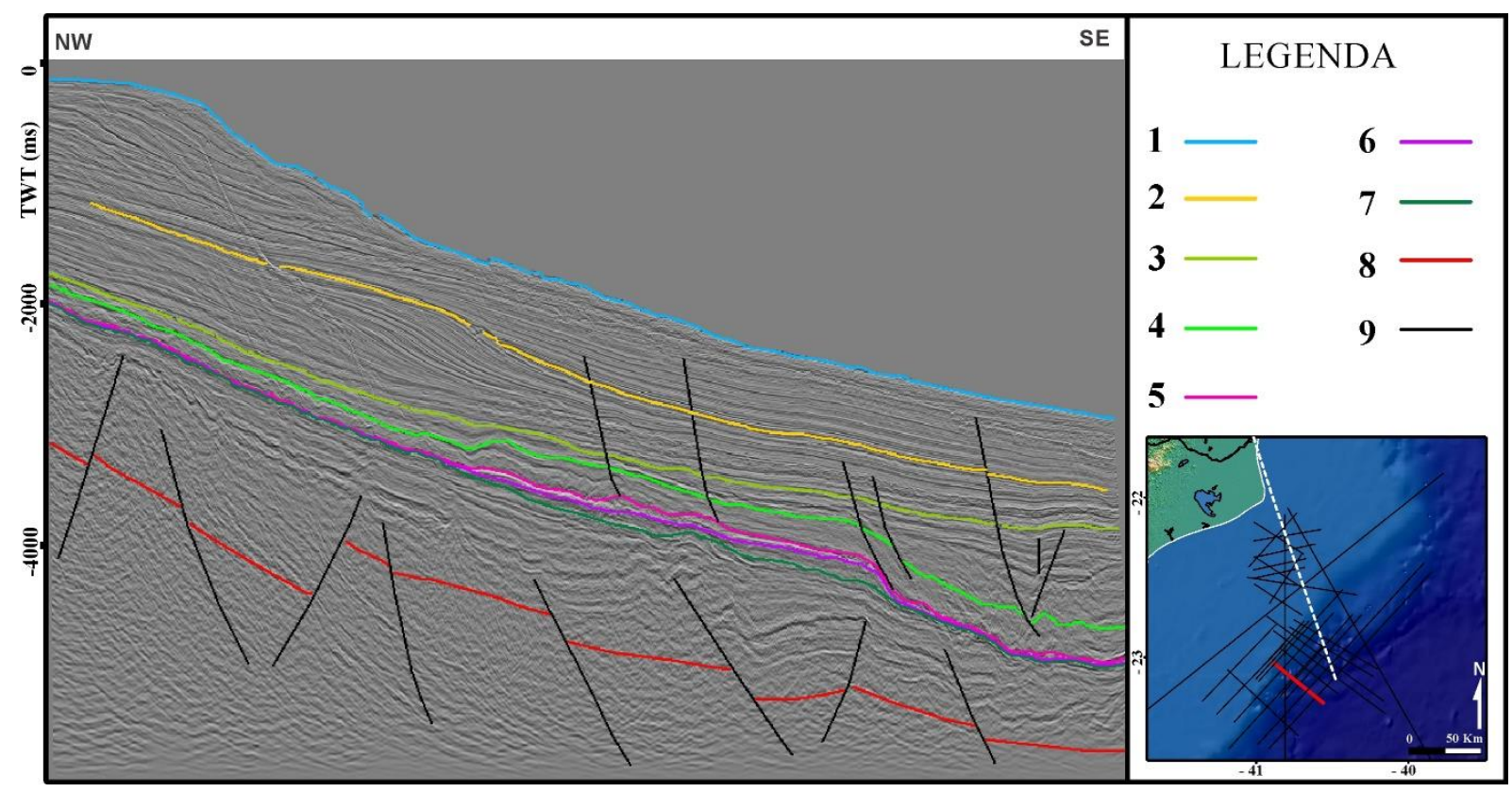

Apêndice A.15: Seção sísmica 2D interpretada, segmento 0228-3624. 1 = Topo da Sequência MiocenoPleistoceno, 2 = Topo da Sequência Paleoceno-Oligoceno, 3 = Topo da Sequência Cenomaniano-Maastrichtiano, 4 = Topo do Albiano, 5 = Topo do Sal, 6 = Topo da Sequência Pós-Rifte, 7 = Topo da Sequência Rifte, $8=$ Embasamento, 9 = Falhas.

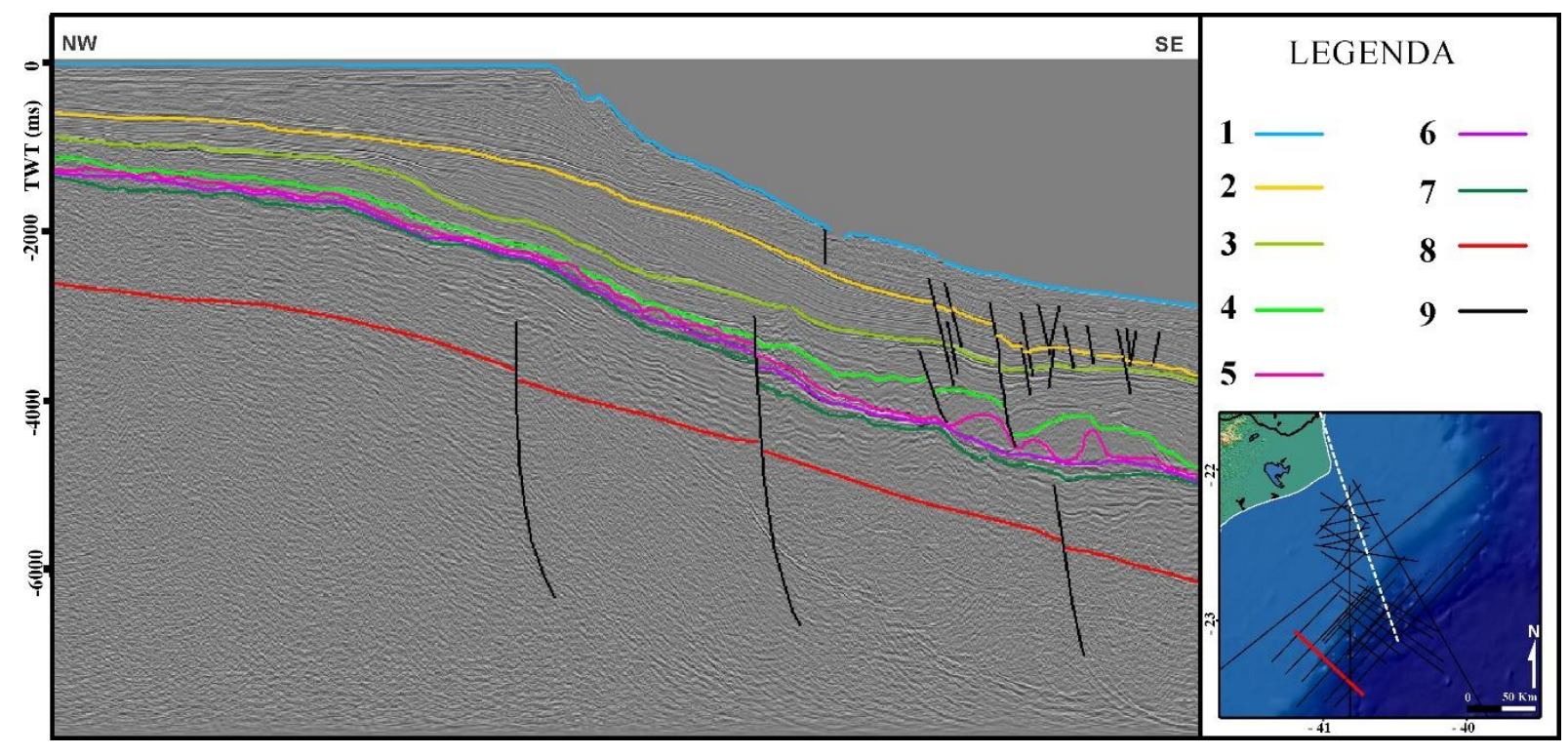

Apêndice A.16: Seção sísmica 2D interpretada, segmento 0228-3636. 1 = Topo da Sequência MiocenoPleistoceno, 2 = Topo da Sequência Paleoceno-Oligoceno, 3 = Topo da Sequência Cenomaniano-Maastrichtiano, 4 = Topo do Albiano, 5 = Topo do Sal, 6 = Topo da Sequência Pós-Rifte, 7 = Topo da Sequência Rifte, $8=$ Embasamento, 9 = Falhas. 


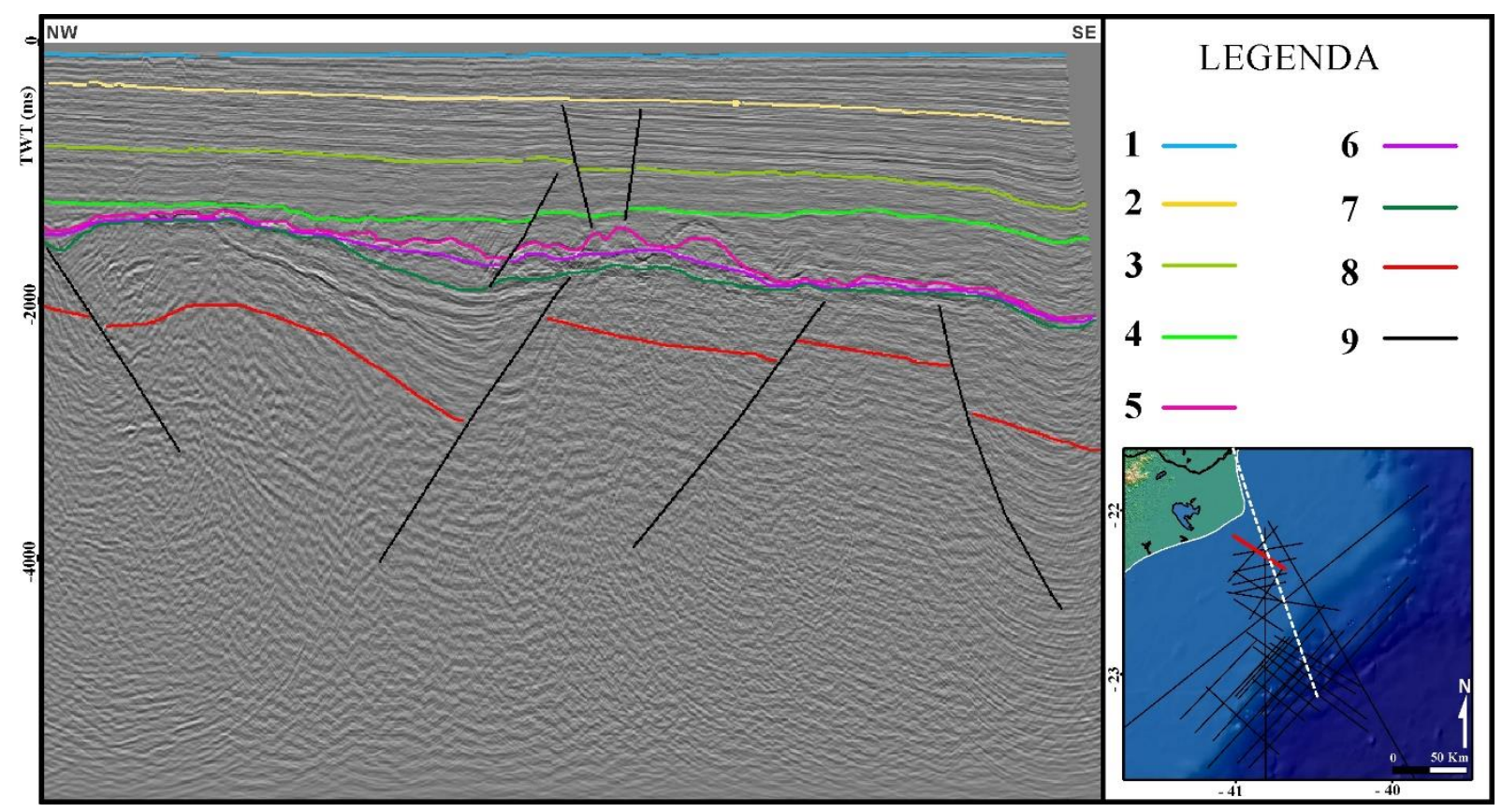

Apêndice A.17: Seção sísmica 2D interpretada, segmento 0231-1218. 1 = Topo da Sequência MiocenoPleistoceno, 2 = Topo da Sequência Paleoceno-Oligoceno, 3 = Topo da Sequência Cenomaniano-Maastrichtiano, 4 = Topo do Albiano, 5 = Topo do Sal, 6 = Topo da Sequência Pós-Rifte, 7 = Topo da Sequência Rifte, $8=$ Embasamento, 9 = Falhas.

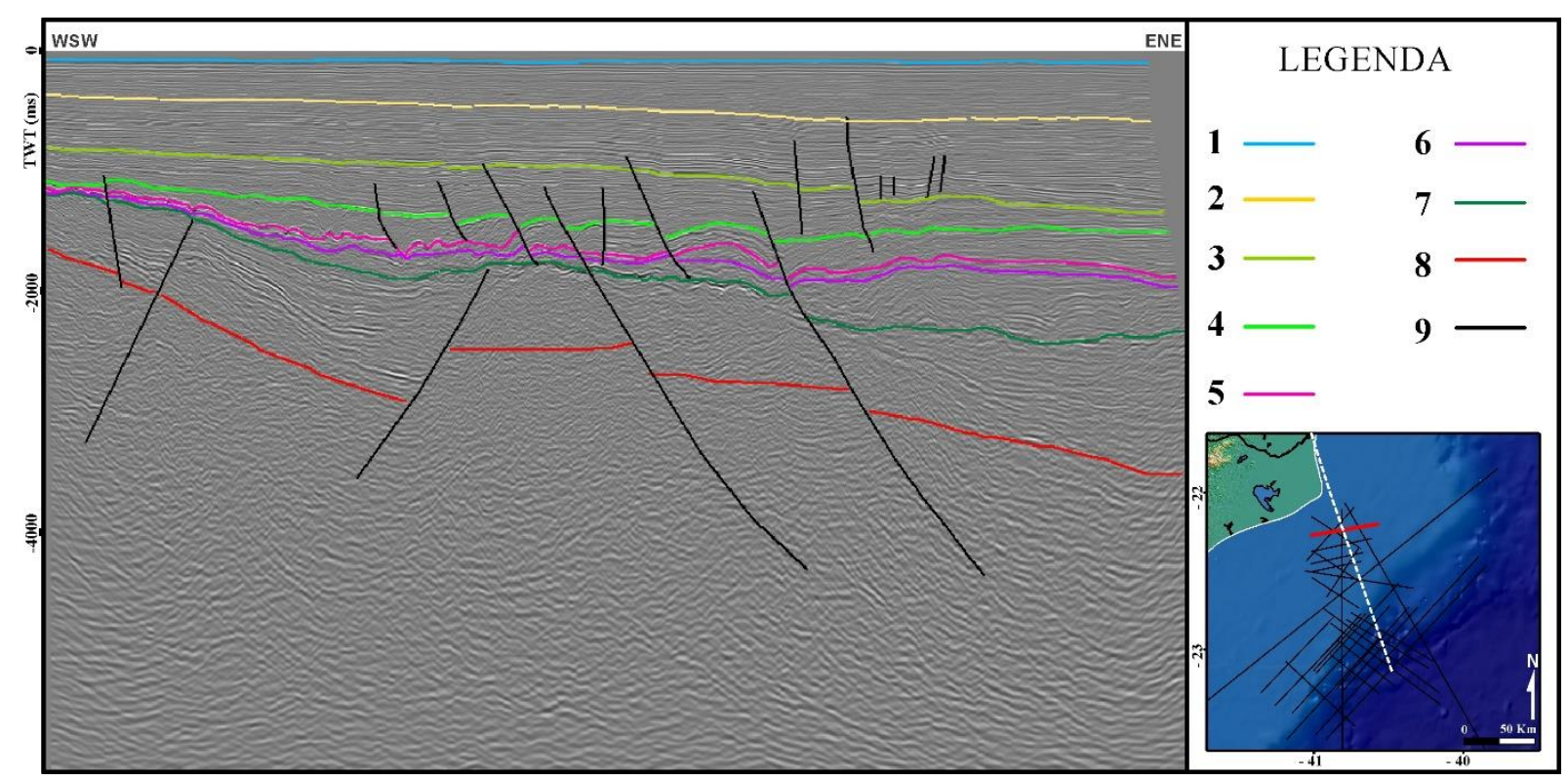

Apêndice A.18: Seção sísmica 2D interpretada, segmento 0231-1233A. 1 = Topo da Sequência MiocenoPleistoceno, 2 = Topo da Sequência Paleoceno-Oligoceno, 3 = Topo da Sequência Cenomaniano-Maastrichtiano, 4 = Topo do Albiano, 5 = Topo do Sal, 6 = Topo da Sequência Pós-Rifte, 7 = Topo da Sequência Rifte, $8=$ Embasamento, 9 = Falhas. 


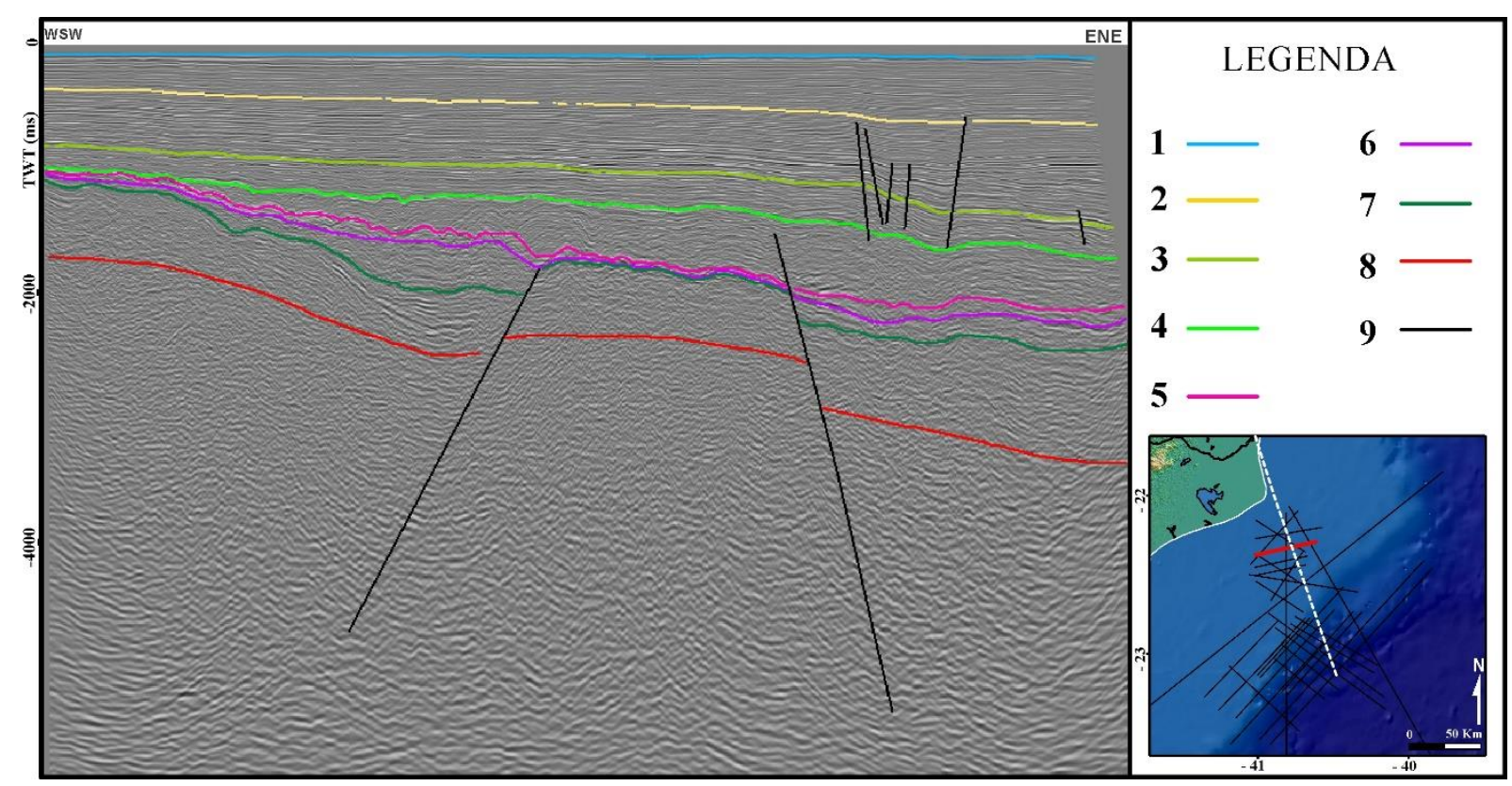

Apêndice A.19: Seção sísmica 2D interpretada, segmento 0231-1237. 1 = Topo da Sequência MiocenoPleistoceno, 2 = Topo da Sequência Paleoceno-Oligoceno, 3 = Topo da Sequência Cenomaniano-Maastrichtiano, 4 = Topo do Albiano, 5 = Topo do Sal, 6 = Topo da Sequência Pós-Rifte, 7 = Topo da Sequência Rifte, $8=$ Embasamento, $9=$ Falhas.

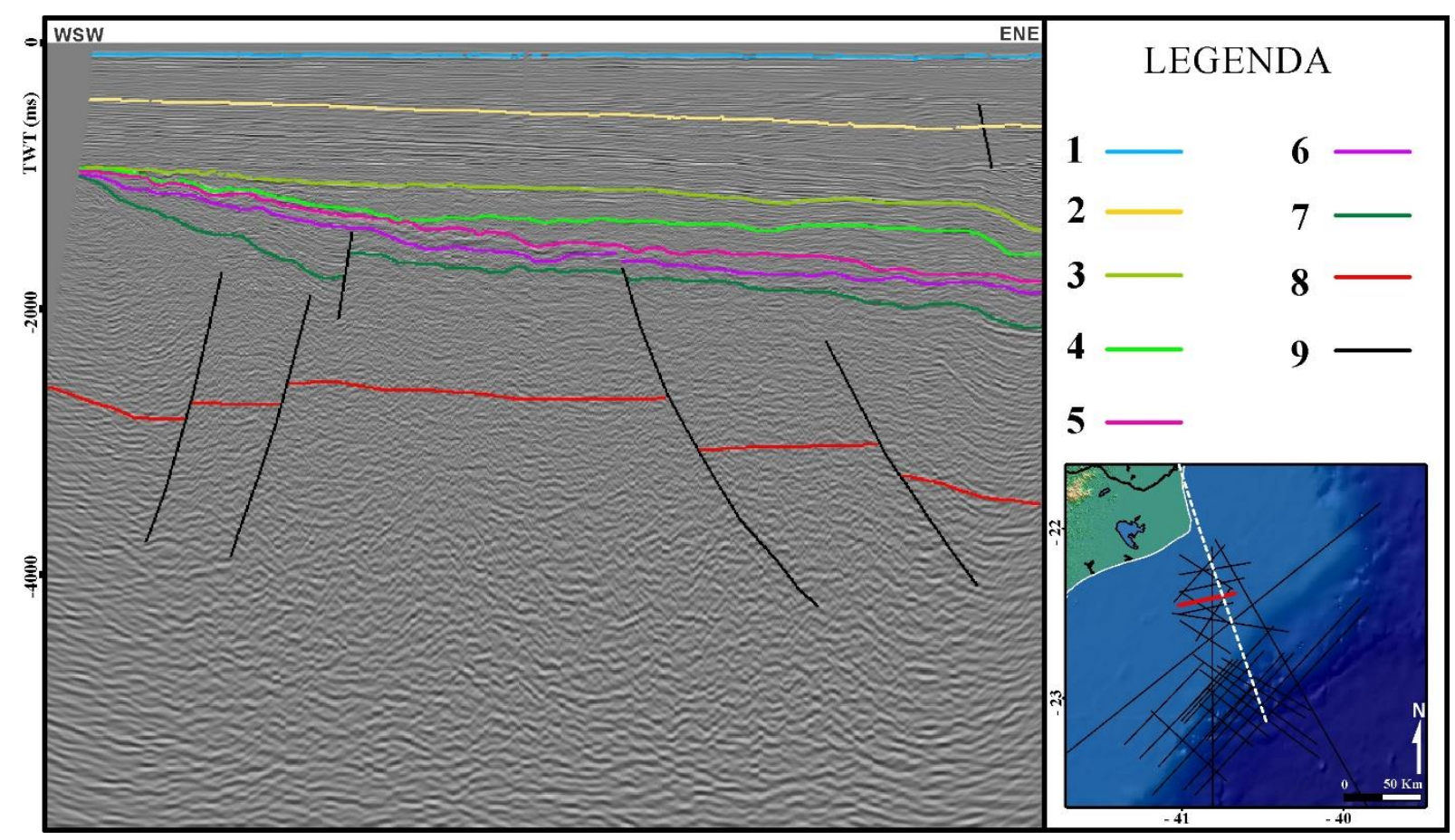

Apêndice A.20: Seção sísmica 2D interpretada, segmento 0231-1240. 1 = Topo da Sequência MiocenoPleistoceno, 2 = Topo da Sequência Paleoceno-Oligoceno, 3 = Topo da Sequência Cenomaniano-Maastrichtiano, 4 = Topo do Albiano, 5 = Topo do Sal, 6 = Topo da Sequência Pós-Rifte, 7 = Topo da Sequência Rifte, $8=$ Embasamento, $9=$ Falhas. 


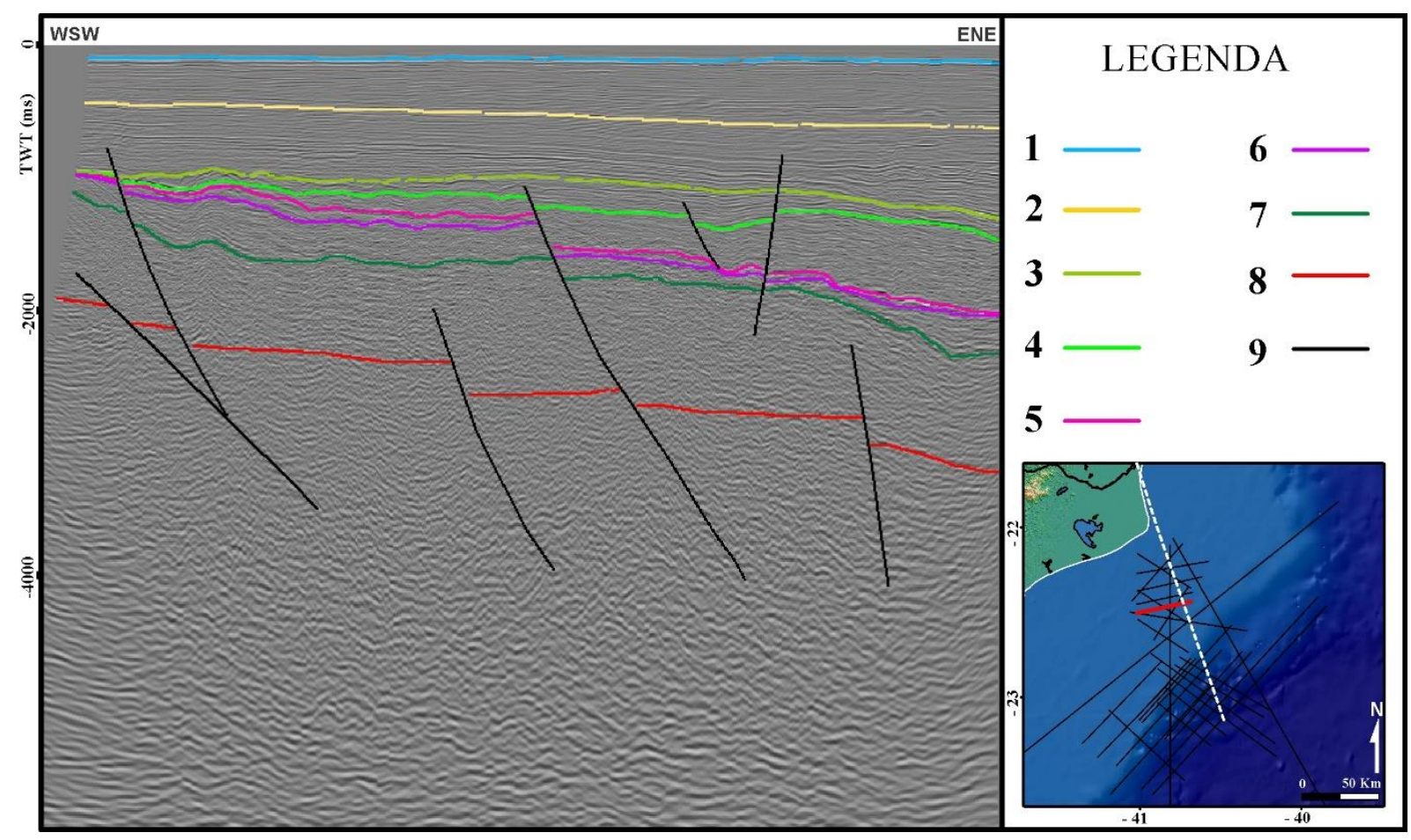

Apêndice A.21: Seção sísmica 2D interpretada, segmento 0231-1242. 1 = Topo da Sequência MiocenoPleistoceno, 2 = Topo da Sequência Paleoceno-Oligoceno, 3 = Topo da Sequência Cenomaniano-Maastrichtiano, 4 = Topo do Albiano, 5 = Topo do Sal, 6 = Topo da Sequência Pós-Rifte, 7 = Topo da Sequência Rifte, $8=$ Embasamento, 9 = Falhas.

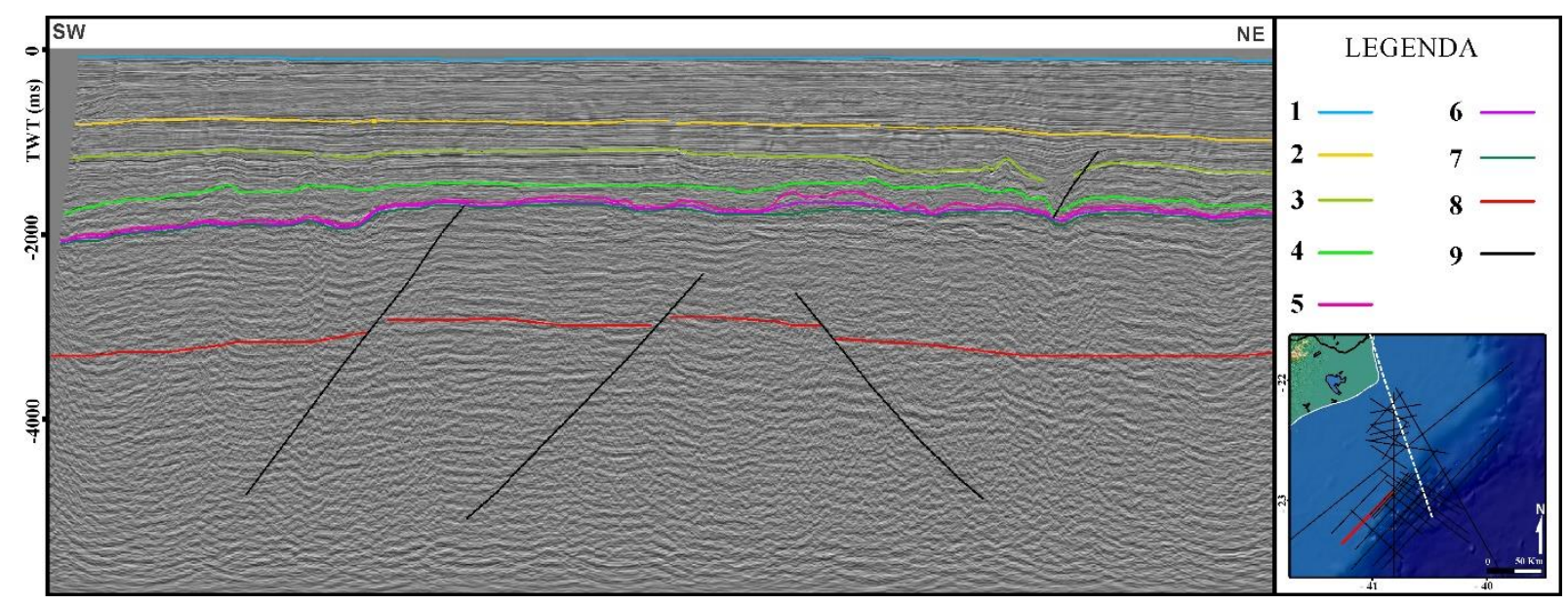

Apêndice A.22: Seção sísmica 2D interpretada, segmento 0241-0655. 1 = Topo da Sequência MiocenoPleistoceno, 2 = Topo da Sequência Paleoceno-Oligoceno, 3 = Topo da Sequência Cenomaniano-Maastrichtiano, 4 = Topo do Albiano, 5 = Topo do Sal, 6 = Topo da Sequência Pós-Rifte, 7 = Topo da Sequência Rifte, $8=$ Embasamento, 9 = Falhas. 


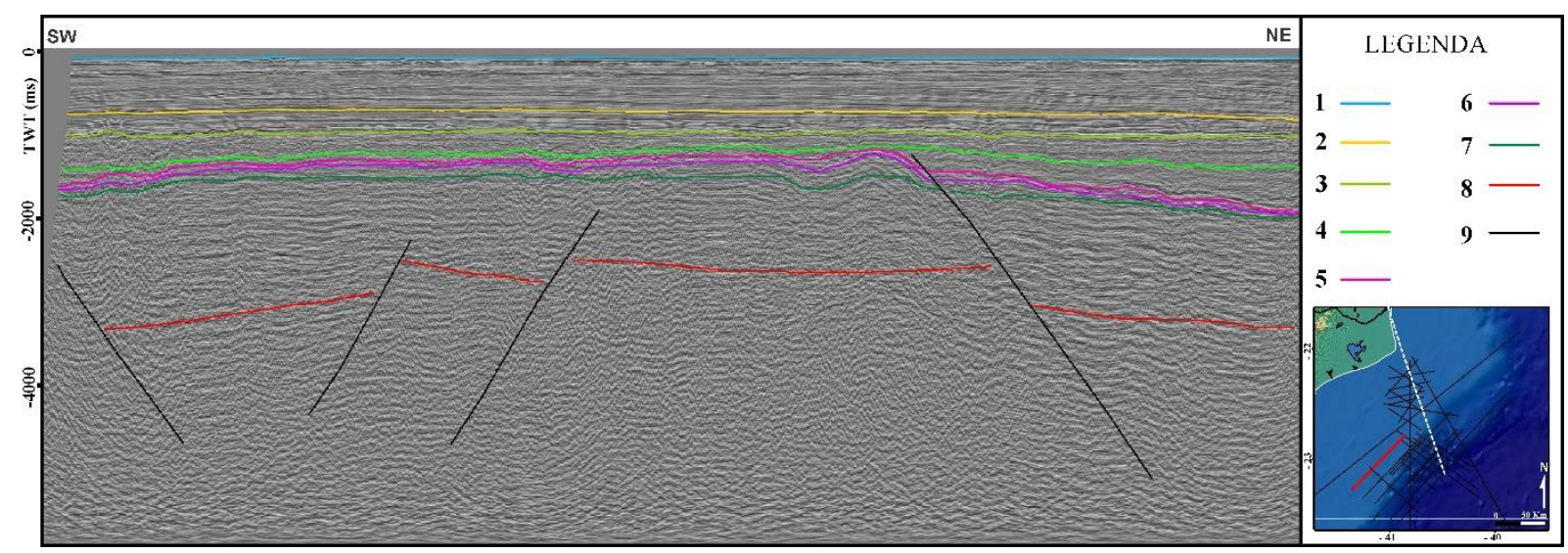

Apêndice A.23: Seção sísmica 2D interpretada, segmento 0241-0664. 1 = Topo da Sequência MiocenoPleistoceno, 2 = Topo da Sequência Paleoceno-Oligoceno, 3 = Topo da Sequência Cenomaniano-Maastrichtiano, 4 = Topo do Albiano, 5 = Topo do Sal, 6 = Topo da Sequência Pós-Rifte, 7 = Topo da Sequência Rifte, $8=$ Embasamento, 9 = Falhas.

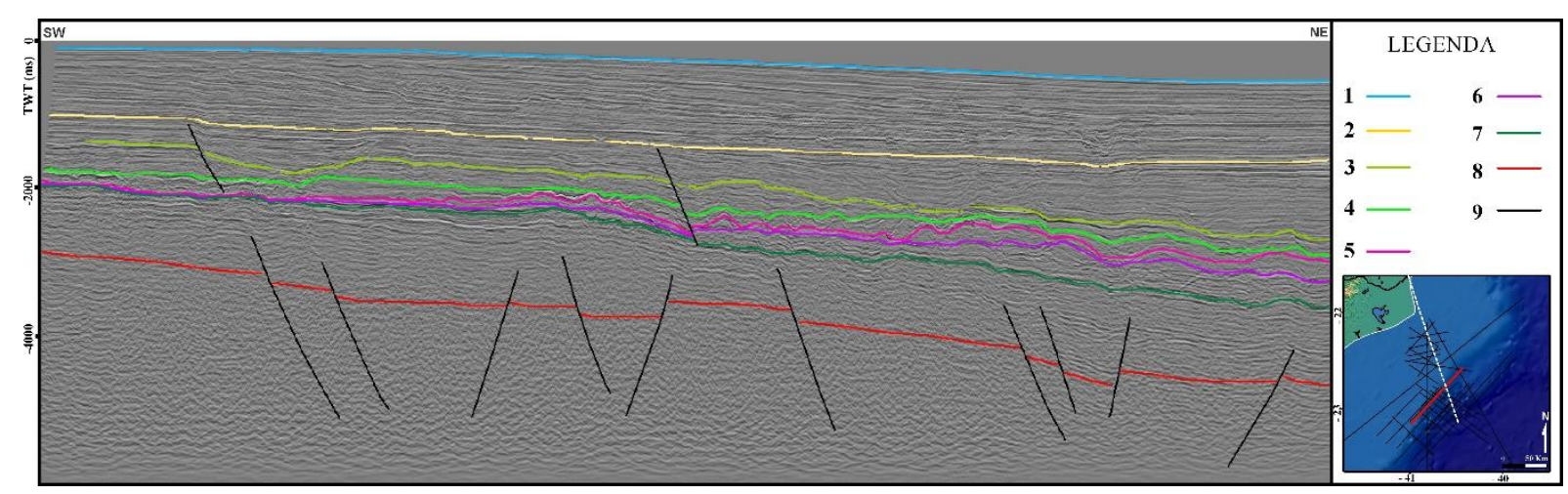

Apêndice A.24: Seção sísmica 2D interpretada, segmento 0046-0122. 1 = Topo da Sequência MiocenoPleistoceno, 2 = Topo da Sequência Paleoceno-Oligoceno, 3 = Topo da Sequência Cenomaniano-Maastrichtiano, 4 = Topo do Albiano, 5 = Topo do Sal, 6 = Topo da Sequência Pós-Rifte, 7 = Topo da Sequência Rifte, $8=$ Embasamento, 9 = Falhas.

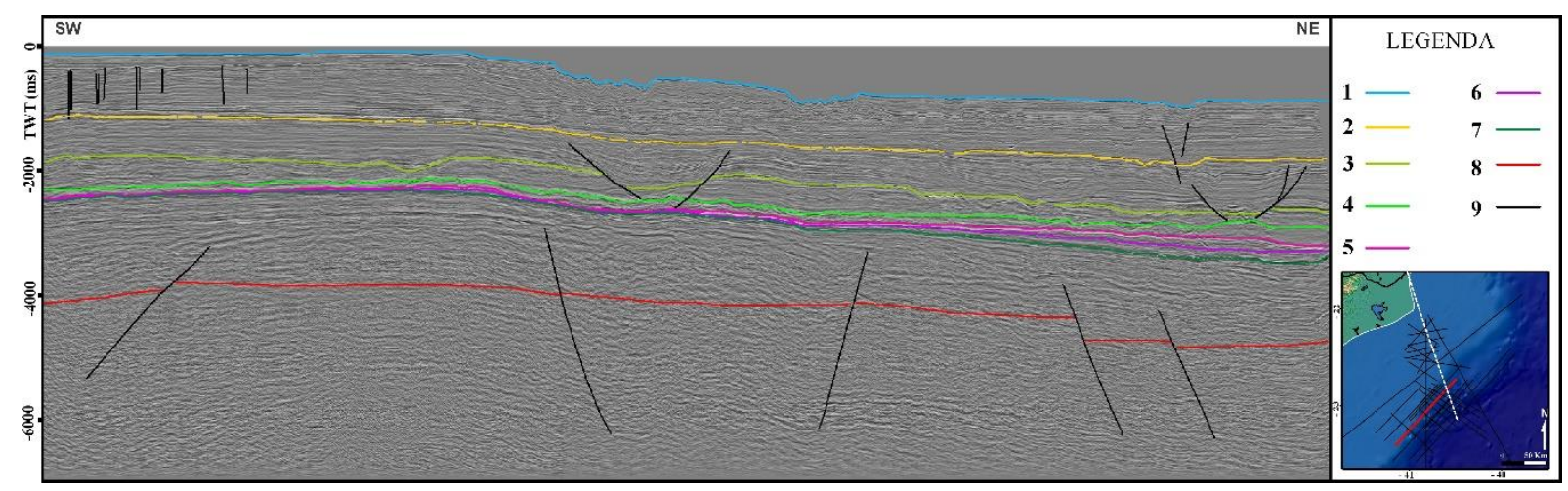

Apêndice A.25: Seção sísmica 2D interpretada, segmento 0221-6870. 1 = Topo da Sequência MiocenoPleistoceno, 2 = Topo da Sequência Paleoceno-Oligoceno, 3 = Topo da Sequência Cenomaniano-Maastrichtiano, 4 = Topo do Albiano, 5 = Topo do Sal, 6 = Topo da Sequência Pós-Rifte, 7 = Topo da Sequência Rifte, $8=$ Embasamento, 9 = Falhas. 


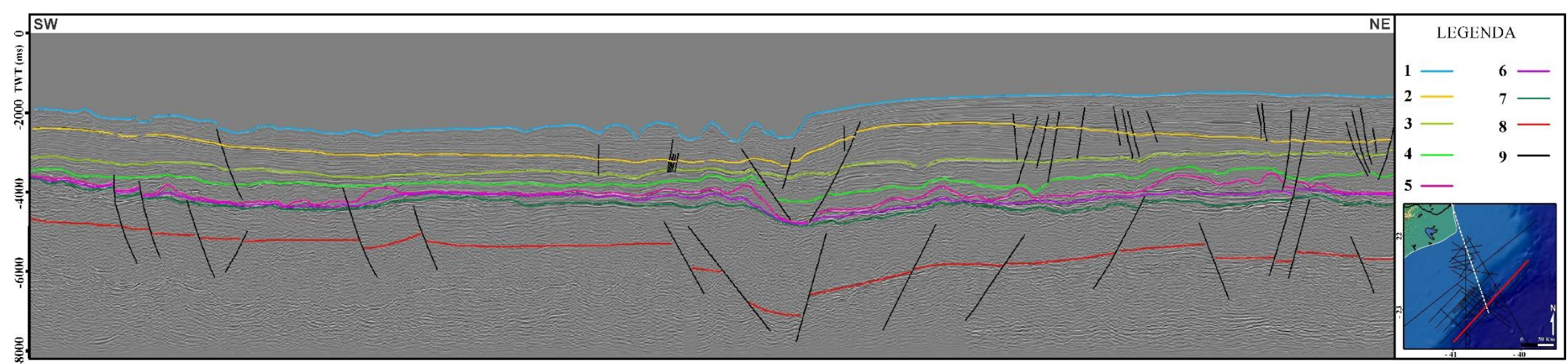

Apêndice A.26: Seção sísmica 2D interpretada, segmento 0221-6960. 1 = Topo da Sequência Mioceno-Pleistoceno, 2 = Topo da Sequência Paleoceno-Oligoceno, $3=$ Topo da Sequência Cenomaniano-Maastrichtiano, 4 = Topo do Albiano, 5 = Topo do Sal, 6 = Topo da Sequência Pós-Rifte, 7 = Topo da Sequência Rifte, $8=$ Embasamento, $9=$ Falhas.

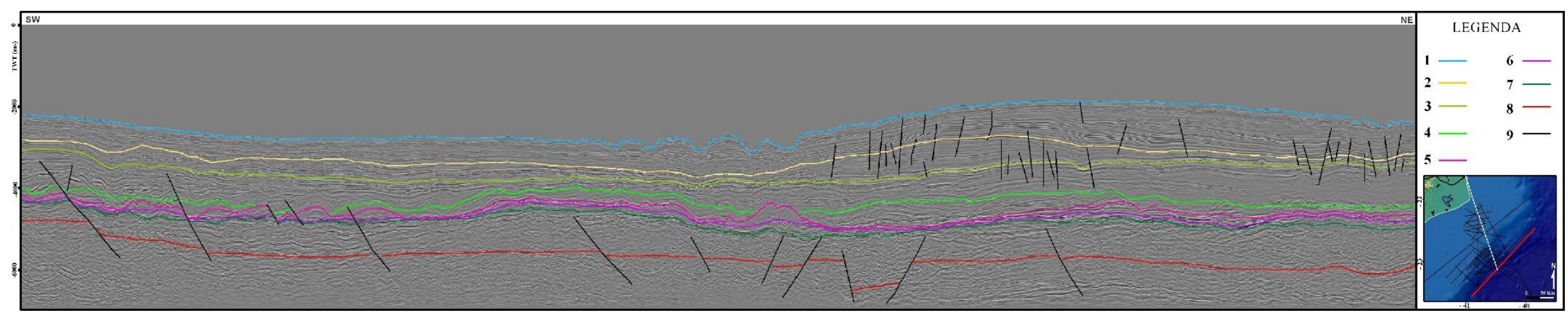

Apêndice A.27: Seção sísmica 2D interpretada, segmento 0221-7000. 1 = Topo da Sequência Mioceno-Pleistoceno, 2 = Topo da Sequência Paleoceno-Oligoceno, $3=$ Topo da Sequência Cenomaniano-Maastrichtiano, 4 = Topo do Albiano, $5=$ Topo do Sal, $6=$ Topo da Sequência Pós-Rifte, 7 = Topo da Sequência Rifte, $8=$ Embasamento, $9=$ Falhas. 


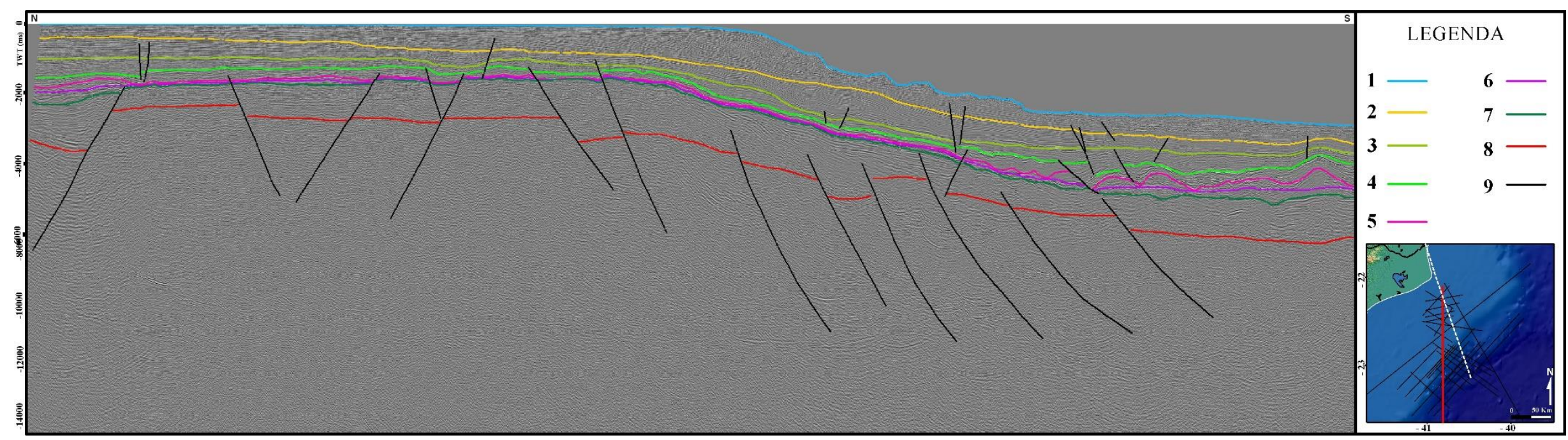

Apêndice A.28: Seção sísmica 2D interpretada, segmento 0239-03651. 1 = Topo da Sequência Mioceno-Pleistoceno, 2 = Topo da Sequência Paleoceno-Oligoceno, $3=$ Topo da Sequência Cenomaniano-Maastrichtiano, $4=$ Topo do Albiano, $5=$ Topo do Sal, $6=$ Topo da Sequência Pós-Rifte, $7=$ Topo da Sequência Rifte, $8=$ Embasamento, $9=$ Falhas.

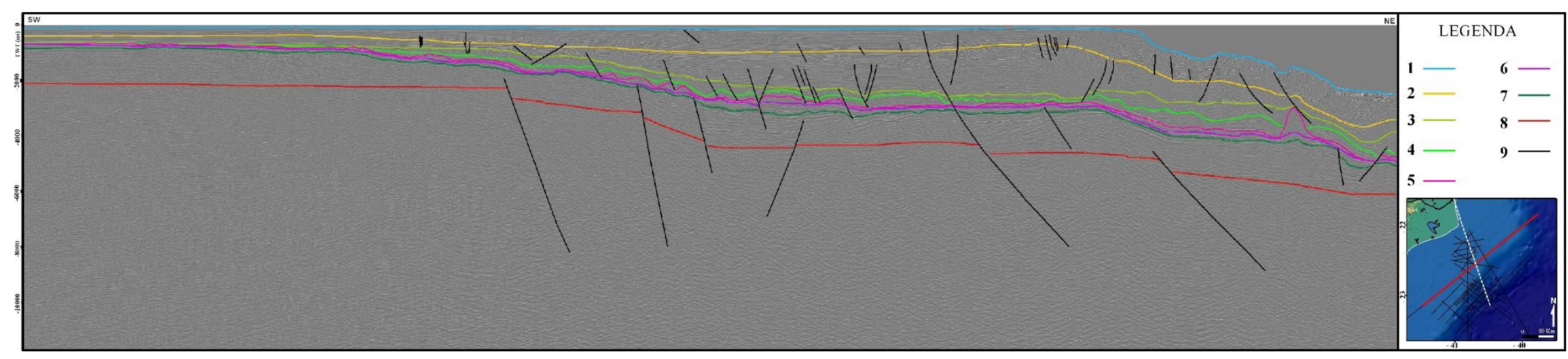

Apêndice A.29: Seção sísmica 2D interpretada, segmento SPP992323. 1 = Topo da Sequência Mioceno-Pleistoceno, 2 = Topo da Sequência Paleoceno-Oligoceno, $3=$ Topo da Sequência Cenomaniano-Maastrichtiano, 4 = Topo do Albiano, $5=$ Topo do Sal, $6=$ Topo da Sequência Pós-Rifte, 7 = Topo da Sequência Rifte, $8=$ Embasamento, $9=$ Falhas. 


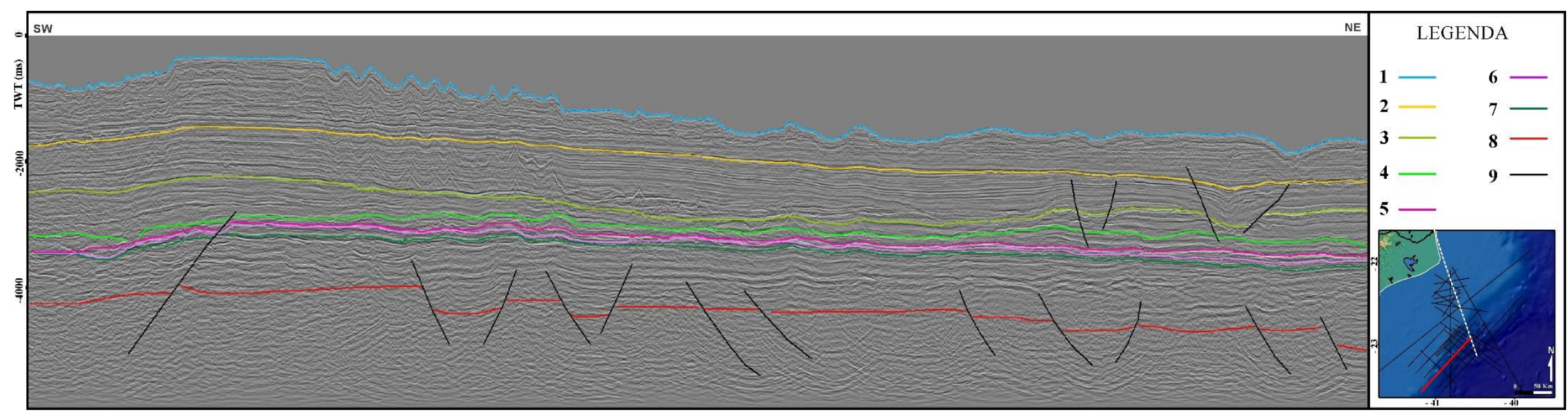

Apêndice A.30: Seção sísmica 2D interpretada, segmento 0228-3682. 1 = Topo da Sequência Mioceno-Pleistoceno, 2 = Topo da Sequência Paleoceno-Oligoceno, $3=$ Topo da Sequência Cenomaniano-Maastrichtiano, 4 = Topo do Albiano, 5 = Topo do Sal, 6 = Topo da Sequência Pós-Rifte, 7 = Topo da Sequência Rifte, $8=$ Embasamento, $9=$ Falhas

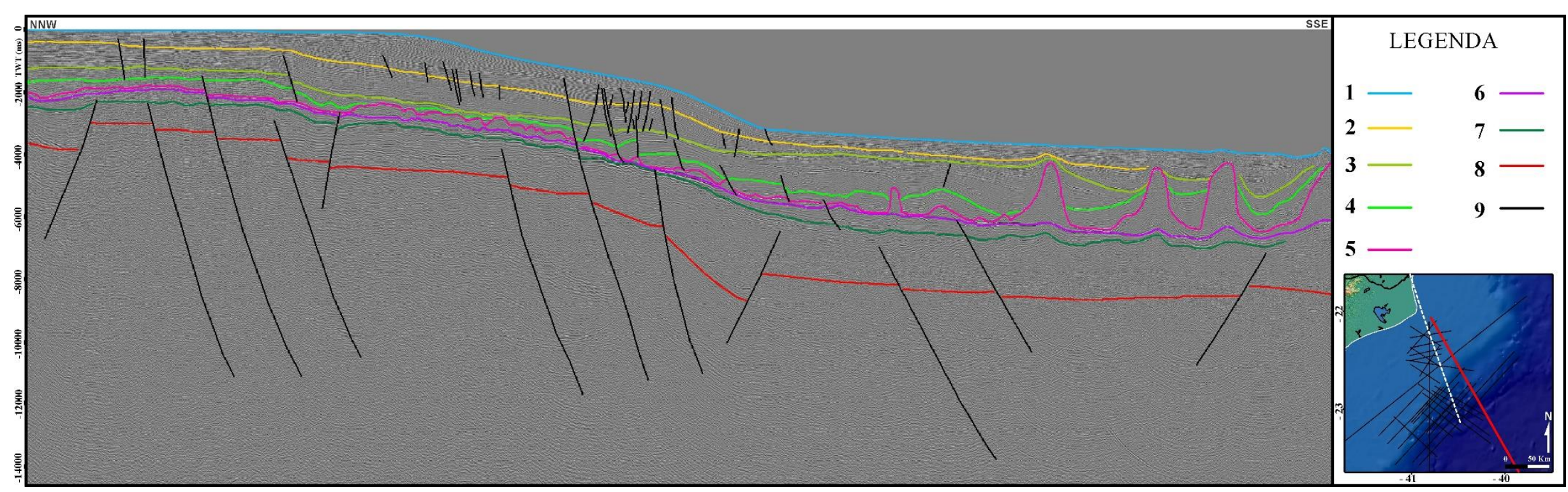


Apêndice A.31: Seção sísmica 2D interpretada, segmento 0239-0363. 1 = Topo da Sequência Mioceno-Pleistoceno, 2 = Topo da Sequência Paleoceno-Oligoceno, $3=$ Topo da Sequência Cenomaniano-Maastrichtiano, 4 = Topo do Albiano, $5=$ Topo do Sal, $6=$ Topo da Sequência Pós-Rifte, 7 = Topo da Sequência Rifte, $8=$ Embasamento, $9=$ Falhas. 